\title{
Avaliação do pré-tratamento do efluente de indústria química com adição de linhagens microbianas especializadas na degradação de compostos tóxicos
}

\section{FLAVIO SILVA MACHADO}

\author{
Dissertação apresentada ao Programa de \\ Pós-Graduação \\ Interunidades \\ em \\ Biotecnologia USP/Instituto Butantan/IPT, \\ para obtenção do Título de Mestre em \\ Biotecnologia.
}


DADOS DE CATALOGAÇÃO NA PUBLICAÇÃO (CIP)

Serviço de Biblioteca e Informação Biomédica do

Instituto de Ciências Biomédicas da Universidade de São Paulo

reprodução não autorizada pelo autor

Machado, Flavio Silva.

Avaliação do pré-tratamento do efluente de indústria química com adição de linhagens microbianas especializadas na degradação de compostos tóxicos / Flavio Silva Machado. -- São Paulo, 2009.

Orientador: José Gregório Cabrera Gomez.

(Mestrado) - Universidade de São Paulo. Instituto de Ciências Biomédicas. Programa de Pós-Graduação Interunidades em Biotecnologia USP/IPT/Instituto Butantan. Área de concentração: Biotecnologia. Linha de pesquisa: Tratamento de efluentes.

Versão do título para o inglês: Evaluation of the industrial wastewater pretreatment adding microbial strains specialized in toxic compounds degradation.

Descritores: 1. Tratamento de esgotos 2. Efluentes industriais 3. Ecotoxicologia 4. Bioaumentação 5. Biodegradação I. Gomez, José Gregório Cabrera II. Universidade de São Paulo. Instituto de Ciências Biomédicas. Programa de Pós-Graduação Interunidades em Biotecnologia III. Título. 


\title{
Avaliação do pré-tratamento do efluente de indústria química com adição de linhagens microbianas especializadas na degradação de compostos tóxicos
}

\section{FLAVIO SILVA MACHADO}

\author{
Dissertação apresentada ao Programa de \\ Pós-Graduação Interunidades em \\ Biotecnologia USP/Instituto Butantan/IPT, \\ para obtenção do Título de Mestre em \\ Biotecnologia. \\ Área de Concentração: Biotecnologia \\ Orientador: Prof. Dr. José Gregório Cabrera \\ Gomez
}




\section{UNIVERSIDADE DE SÃO PAULO \\ Programa de Pós-Graduação Interunidades em Biotecnologia}

Universidade de São Paulo, Instituto Butantan, Instituto de Pesquisas Tecnológicas

Candidato(a):

Título da Dissertação:

Orientador(a):
Flavio Silva Machado.

Avaliação do pré-tratamento do efluente de indústria química com adição de linhagens microbianas especializadas na degradação de compostos tóxicos .

José Gregório Cabrera Gomez.

A Comissão Julgadora dos trabalhos de Defesa da Dissertação de Mestrado, em sessão pública realizada a ...................................
( ) Aprovado(a)
( ) Reprovado(a)

Examinador(a): Assinatura:

Nome:

Instituição:

Examinador(a): Assinatura:

Nome:

Instituição:

Presidente: Assinatura:

Nome:

Instituição: 


\section{AGRADECIMENTOS}

Ao meu orientador, José Gregório Cabrera Gomez, pelo apoio em todas as etapas do trabalho e principalmente por ter acreditado no projeto.

À minha família, por todo o apoio e incentivo, que foram fundamentais para que eu tivesse a motivação necessária para o desenvolvimento do trabalho.

À Thatiane Mendonça, pela valiosa e incansável colaboração, pela bondade e amizade ao longo de todas as etapas do trabalho.

Ao pessoal dos laboratórios 136 e 172, do Departamento de Microbiologia do Instituto de Ciências Biomédicas da Universidade de São Paulo, em especial Sayuri, Daniela e Marco Antônio, por toda a colaboração prestada.

Aos meus superiores na Cia. de Saneamento Básico do Estado de São Paulo, Rosângela Carvalho, Ivana Wuo e José Batista, por terem me permitido desenvolver o trabalho.

Aos colegas da Sabesp Sara, Alan, Carmem, Nina, Terezinha, Sheila e em especial minha querida amiga Roseli Sposito, profissional de indubitável ética.

À Dra. Sueli Borrely, do Instituto de Pesquisas Energéticas e Nucleares e Qca. Márcia Moribe, do laboratório de orgânica da Sabesp. 
"Não se pode ensinar alguma coisa a alguém, pode-se apenas auxiliar a descobrir por si mesmo."

Galileu Galilei 


\section{RESUMO}

\section{MACHADO, F. S. Avaliação do pré tratamento do efluente de indústria química com adição de linhagens microbianas especializadas na degradação de compostos tóxicos. 2009. $98 \mathrm{f}$. Dissertação (Mestrado em Biotecnologia) - Instituto de Ciências Biomédicas, Universidade de São Paulo, São Paulo, 2009.}

As indústrias químicas são consideradas como o segmento industrial que gera os efluentes mais perigosos ao meio ambiente. O lançamento desses em corpos receptores ou em redes coletoras de esgoto é regulado por legislação federal e estadual. Em virtude das concentrações expressivas de poluentes, tanto orgânicos quanto inorgânicos, os efluentes de indústrias químicas podem interferir na atividade da biomassa de estações de tratamento de efluentes (E.T.E.), diminuindo sua eficiência e gerando efluentes tratados em desacordo com a legislação pertinente. Nesse caso, tais efluentes, mesmo tratados, podem conferir toxicidade ao ecossistema aquático. Para prevenir tais efeitos, o recebimento de efluentes industriais em E.T.E.s pode ser precedido por pré-tratamento, dentre os quais, o biológico, otimizado pela adição de microrganismos com capacidade de degradar poluentes. Foram isolados microrganismos da própria estação de tratamento com capacidade de degradar os compostos identificados como responsáveis pela toxicidade do efluente final da E.T.E.: benzeno, clorofórmio, 1,2-dicloroetano, pentaclorofenol, tricloroeteno, tolueno e $p$-xileno. Ensaios de ecotoxicidade aguda confirmaram a relação desses compostos com as ocorrências de inibição do processo biológico da estação de tratamento. Foram realizados testes de bioaumentação para pré tratar o efluente industrial antes de seu recebimento na E.T.E., com as linhagens isoladas. Os testes foram avaliados através de ensaios físico-químicos e de toxicidade aguda para Vibrio fischeri e Daphnia similis. Os resultados obtidos apontam que a estação de tratamento possui microrganismos capazes de degradar os compostos tóxicos causadores de toxicidade e que os testes de bioaumentação realizados com consórcios microbianos mostraram-se mais eficientes do que os realizados com linhagens puras. Além disso, o pré tratamento do efluente industrial mostrou-se ser uma melhor alternativa para redução de toxicidade ao invés da adição de linhagens ou consórcios diretamente no reator biológico da E.T.E. Os testes de toxicidade mostraram-se ferramentas muito úteis para demonstrar que o pré tratamento do efluente industrial reduziu acentuadamente os níveis de toxicidade do efluente final da estação de tratamento. Analises de restrição de DNA ribossomal demonstraram a diversidade da microbiota degradadora dos poluentes orgânicos.

Palavras-chave: Tratamento de esgotos. Efluentes industriais. Ecotoxicologia. Bioaumentação. Biodegradação. 


\begin{abstract}
MACHADO, F. S. Evaluation of the industrial wastewater pretreatment adding microbial strains specialized in toxic compounds degradation. $98 \mathrm{f}$. Master thesis (Biotechnology) - Instituto de Ciências Biomédicas, Universidade de São Paulo, São Paulo, 2009.
\end{abstract}

Chemical industries are considered the industrial sector that generates the most dangerous effluents to the environment. The disposal of these effluents in receptor bodies is regulated by federal and state laws. Due to the high pollutant concentration, either organics or inorganics, the chemical industries effluents may interferer in the biomass activity in wastewater treatment plants (WWTP), what may reduce its efficiency and generate effluents in disagreement to the concerned law. Such effluents, even treated, may cause toxicity to the aquatic ecosystem. In order to prevent such effects, the industrial effluents disposal in WWTPs can be preceded by biological pretreatment, which can be optimized by adding microorganisms capable of pollutants degradation. Microorganism strains with the degrading capacity over organic compounds were isolated from the wastewater treatment plant. These strains are able to degrade the compounds identified as the responsible for toxicity levels in the WWTP final effluent: benzene, chloroform, 1,2-dichloroethane, pentachlorophenol, trichloroethene, tolune and $p$-xylene. Acute ecotoxicity tests have confirmed the relationship between such compounds and the inhibition events over the WWTP biological process. Bioaugmentation tests aiming the chemical effluent pretreatment were performed before it has been disposed in the WWTP, by using the isolated strains. The tests were evaluated through physical-chemical analysis and acute toxicity tests for Vibrio fischeri and Daphnia similis. The results showed that the WWTP contain microorganisms that are capable of degrading the toxic compounds responsible for toxicity, and the bioaugmentation tests performed with microbial consortia were more efficient than the ones performed with pure strains. Moreover, the industrial pretreatment was a better option for toxicity reduction than the microbial or consortia addiction directly in the WWTP biologic reactor. The toxicity tests were useful tools to demonstrate that the industrial effluent pretreatment reduced intensely the toxicity levels in the WWTP final effluent. Amplified rDNA restriction analysis showed the diversity of the organic pollutants degraders.

Key words: Wastewater treatment. Industrial effluents. Ecotoxicology. Bioaugmentation. Biodegradation. 


\section{LISTA DE FIGURAS}

Figura 1 - Representação esquemática das unidades que compõem o sistema de lodos ativados.

Figura 2 - Alguns organismos utilizados em ensaios ecotoxicologicos

Figura 3 - Fluxograma de processo da E.T.E. objeto de estudo

Figura 4 - Croqui esquemático demonstrando o fluxo do efluente gerado na indústria química.

Figura 5 - Esquema de montagem dos reatores para simulação do recebimento de efluente industrial para amostragem do efluente final.

Figura 6 - Esquema de diluição das amostras de biomassa da estação de tratamento e inoculação em placas de Petri..

Figura 7 - Frasco erlenmeyer com $150 \mathrm{~mL}$ de meio mineral com tubo contendo fonte de carbono, utilizado nas leituras da $\mathrm{DO}_{610}$.

Figura 8 - Esquema dos testes de bioaumentação realizados no efluente industrial (teste A) e diretamente no biorreator que simulou o tanque de aeração (teste B)

Figura 9 - Fotografias da calha do vertedor do efluente final da E.T.E. objeto de estudo em dois momentos.

Figura 10 - Crescimento de isolados bacterianos em meio mínimo contendo benzeno como única fonte de carbono.

Figura 11 - Crescimento de isolados bacterianos em meio mínimo contendo clorofórmio como única fonte de carbono. 
Figura 12 - Crescimento de isolados bacterianos em meio mínimo contendo 1,2-dicloroetano como única fonte de carbono.

Figura 13 - Crescimento de isolados bacterianos em meio mínimo contendo pentaclorofenol como única fonte de carbono.

Figura 14 - Crescimento de isolados bacterianos em meio mínimo contendo tolueno como única fonte de carbono.

Figuras 15 - Crescimento de isolados bacterianos em meio mínimo contendo tricloroeteno como única fonte de carbono.

Figura 16 - Crescimento de isolados bacterianos em meio mínimo contendo $p$ xileno como única fonte de carbono.

Figura 17 - Fotografia do produto de PCR do gene 16S rDNA.

Figura 18 - Fotografia do produto da digestão do gene 16S rDNA com a enzima de restrição Haelll.

Figura 19 - Fotografia do produto da digestão do gene $16 \mathrm{~S}$ rDNA com a enzima de restrição Hhal.

Figura 20 - Perfis de restrição e classificação dos isolados em diferentes grupos após digestão a $30 \stackrel{\circ}{\mathrm{C}}$ por $16 \mathrm{~h}$.

Figura 20a - com a enzima de restrição Haelll.

Figura 20b - com a enzima de restrição Hhal. 


\section{LISTA DE TABELAS}

Tabela 1 - Testes de toxicidade padronizados pela ABNT e CETESB.

Tabela 2 - Toxicidades agudas de diferentes efluentes industriais para Daphnia magna após $48 \mathrm{~h}$

Tabela 3 - Exemplos de estudos recentes de bioaumentação em solo, lodos ativados e aqüífero.

Tabela 4 - Métodos para monitoramento da sobrevivência e atividade dos microrganismos utilizados em bioaumentação.

Tabela 5 - Volumes de efluentes domésticos e não-domésticos recebidos via rede e via caminhão na E.T.E. objeto de estudo durante o período de junho de 2007 a maio de 2008

Tabela 6 - Caracterização do esgoto afluente e efluente da ETE objeto de estudo. Valores médios de junho de 2007 a maio de 2008.

Tabela 7 - Contaminantes presentes no efluente das células produtivas da indústria química.

Tabela 8 - Valores mínimos, médios e máximos de concentrações de parâmetros físico-químicos obtidos na caracterização do efluente industrial durante o período de junho de 2007 a junho de 2008 e variação de ocorrência dos parâmetros.

Tabela 9 - Poluentes orgânicos detectados em amostragens de efluente final de biorreatores alimentados com (reator 1) e sem (reator 2) efluente proveniente da indústria química.

Tabela 10 - Resultados de ensaios de remoção de DQO, turbidez, nitrogênio amoniacal, poluentes orgânicos e ensaios ecotoxicológicos em amostras do efluente final da ETE estudada durante eventos de inibição no sistema e sob operação normal.

Tabela 11 - Densidade total de microrganismos (UFC/mL) por fonte de carbono, código de identificação das linhagens e número de microrganismos isolados por fonte de carbono.

Tabela 12 - Concentração ( $\mu \mathrm{g} / \mathrm{L})$ dos compostos orgânicos presentes em diferentes pontos da estação de tratamento de esgotos objeto de estudo em 1997

Tabela 13 - Resultados de $\mathrm{pH}$ do biorreator utilizado no pré tratamento do efluente industrial antes e depois da introdução dos consórcios microbianos.......

Tabela 14 - Resultados de DQO do biorreator utilizado no pré tratamento do efluente industrial antes e depois da introdução dos consórcios microbianos. 
Tabela 15 - Resultados de SS do biorreator utilizado no pré tratamento do efluente industrial antes e depois da introdução dos consórcios microbianos

Tabela 16 - Resultados de nitrogênio amoniacal do biorreator utilizado no pré tratamento do efluente industrial antes e depois da introdução dos consórcios microbianos.

Tabela 17 - Resultados de surfactantes do biorreator utilizado no pré tratamento do efluente industrial antes e depois da introdução dos consórcios microbianos.

Tabela 18 - Resultados de fenol do biorreator utilizado no pré tratamento do efluente industrial antes e depois da introdução dos consórcios microbianos.

Tabela 19 - resultados dos ensaios de toxicidade para $D$. similis e $V$. fischeri, expressos em Unidades Tóxicas, do efluente industrial antes (A) e depois (B) da adição das linhagens microbianas puras e do efluente final $(C)$ dos reatores em batelada que simularam o tanque de aeração da E.T.E., após recebimento do efluente industrial submetido ao pré-tratamento

Tabela 20 - resultados dos ensaios de toxicidade para $D$. similis e $V$. fischeri, expressos em Unidades Tóxicas, do efluente industrial antes (A) e depois (B) da adição dos consórcios microbianos e do efluente final (C) dos reatores em batelada após recebimento de efluente industrial submetido ao pré-tratamento...

Tabela 21 - Resultados de pH do biorreator que simulou o tanque de aeração da E.T.E. ao receber efluente industrial sem pré tratamento, antes e depois da introdução dos consórcios microbianos.

Tabela 22 - Resultados de DQO do biorreator que simulou o tanque de aeração da E.T.E. ao receber efluente industrial sem pré tratamento, antes e depois da introdução dos consórcios microbianos.

Tabela 23 - Resultados de SS do biorreator que simulou o tanque de aeração da E.T.E. ao receber efluente industrial sem pré tratamento, antes e depois da introdução dos consórcios microbianos.

Tabela 24 - Resultados de nitrogênio amoniacal do biorreator que simulou o tanque de aeração da E.T.E. ao receber efluente industrial sem pré tratamento, antes e depois da introdução dos consórcios microbianos.

Tabela 25 - Resultados de surfactantes do biorreator que simulou o tanque de aeração da E.T.E. ao receber efluente industrial sem pré tratamento, antes e depois da introdução dos consórcios microbianos.

Tabela 26 - Resultados de fenol do biorreator que simulou o tanque de aeração da E.T.E. ao receber efluente industrial sem pré tratamento, antes e depois da introdução dos consórcios microbianos. 
Tabela 27 - resultados dos ensaios de toxicidade para $D$. similis e $V$. fischeri do afluente bruto e do efluente final dos reatores em batelada que simularam o tanque de aeração da ETE, bioaumentados com linhagens microbianas puras, após recebimento de efluente industrial sem pré tratamento

Tabela 28 - resultados dos ensaios de toxicidade para $D$. similis e $V$. fischeri do afluente bruto e do efluente final dos reatores em batelada que simularam o tanque de aeração da ETE, bioaumentados com consórcios microbianos, após recebimento de efluente industrial sem pré tratamento.

Tabela 29 - resultados dos ensaios de toxicidade para $D$. similis, expressos em Unidades Tóxicas, do efluente industrial, afluente bruto e efluente final dos reatores em batelada que simularam o tanque de aeração da ETE, bioaumentados com linhagens microbianas puras, após recebimento de efluente industrial sem pré tratamento.

Tabela 30 - resultados dos ensaios de toxicidade para $V$. fischeri, expressos em Unidades Tóxicas, do efluente industrial, afluente bruto e efluente final dos reatores em batelada que simularam 0 tanque de aeração da ETE, bioaumentados com linhagens microbianas puras, após recebimento de efluente industrial sem pré tratamento.

Tabela 31 - resultados dos ensaios de toxicidade para $D$. similis, expressos em Unidades Tóxicas, do efluente industrial, do afluente bruto e do efluente final dos reatores em batelada que simularam o tanque de aeração da ETE, bioaumentados com consórcios microbianos, após recebimento de efluente industrial sem pré tratamento.

Tabela 32 - resultados dos ensaios de toxicidade para $V$. fischeri, expressos em Unidades Tóxicas, do efluente industrial, do afluente bruto e do efluente final dos reatores em batelada que simularam o tanque de aeração da ETE, bioaumentados com consórcios microbianos, após recebimento de efluente industrial sem pré tratamento

Tabela 33 - Características fenotípicas das 21 linhagens microbianas isoladas e selecionadas para os testes de bioaumentação.

Tabela 34 - Classificação das linhagens microbianas isoladas de acordo com as características fenotípicas (coloração da colônia, oxidase, catalase e gram)...

Tabela 35 - Grupos de classificação dos isolados após digestão com as enzimas Haelll e Hhal, com o mesmo perfil de restrição 


\section{SUMÁRIO}

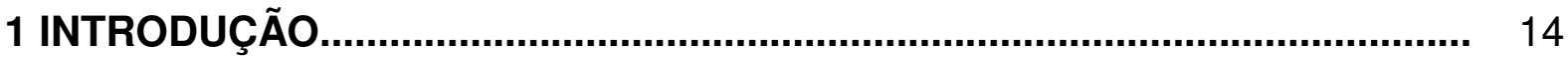

2 REVISÃO DE LITERATURA................................................................... 16

2.1 Tratamento de efluentes por sistema de lodos ativados.......................... 16

2.2 Efluentes não-domésticos.................................................................... 18

2.2.1 Efluentes de indústrias químicas......................................................... 21

2.2.2 Inibição sobre o processo de lodos ativados.......................................... 23

2.3 Ensaios ecotoxicológicos........................................................................ 25

2.4 Tratamento biológico de efluentes industriais por bioaumentação.......... 30

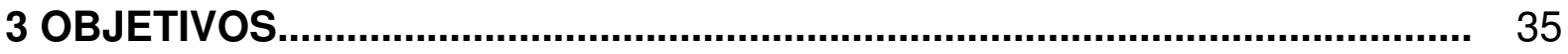

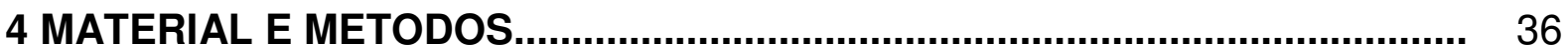

4.1 Caracterizaçao da estação de tratamento de efluentes - E.T.E................ 36

4.1.1 Caracterização do esgoto afluente e efluente da E.T.E.......................... 38

4.2 Descrição da indústria química geradora de efluente............................... 39

4.2.1 Caracterização físico-química do efluente industrial............................ 40

4.2.2 Determinação dos poluentes orgânicos no efluente da indústria

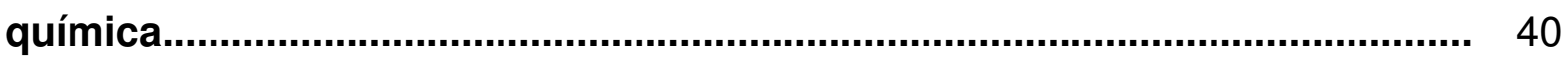

4.2.2.1 Ensaios de cromatografia................................................................. 43

4.2.2.2 Detecção de fenol por espectrofotometria............................................ 43

4.3 Ensaios de toxicidade aguda para organismos Daphnia similis e Vibrio

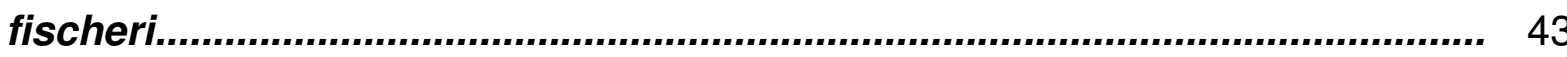

4.4 Obtenção das linhagens microbianas.................................................... 44

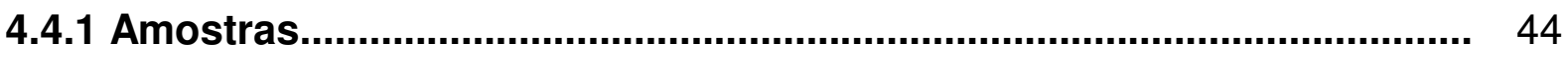

4.4.2 Isolamento dos microrganismos.......................................................... 45

4.4.3 Avaliação do crescimento microbiano em diferentes fontes de

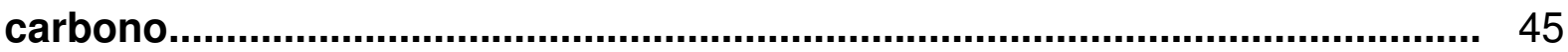

4.4.3.1 Pré inoculo............................................................................... 45

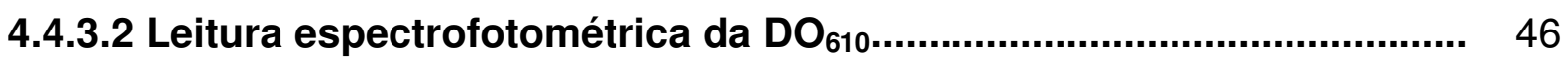

4.5 Testes de Bioaumentaçao................................................................... 47

4.5.1 Pré-tratamento das amostras do efluente da indústria química............. 48

4.5.2 Bioaumentação direta no reator biológico.............................................. 49

4.6 Caracterização dos isolados..................................................................... 53

4.6.1 Caracterização fenotípica................................................................ 53 
4.6.2 Caracterização molecular.................................................................. 53

4.6.2.1 Extração do DNA genômico dos isolados............................................. 53

4.6.2.2 Amplificação da região 16S rDNA..................................................... 54

4.6.2.3 Análise de restrição de DNA ribossomal - ARDRA.................................. 54

5 RESULTADOS E DISCUSSÃO............................................................... 51

5.1 Caracterização do efluente industrial..................................................... 51

5.2 Ensaios de toxicidade, desempenho operacional e poluentes orgânicos no efluente final da E.T.E............................................................. 54

5.3 Isolamento e seleção dos microrganismos............................................. 57

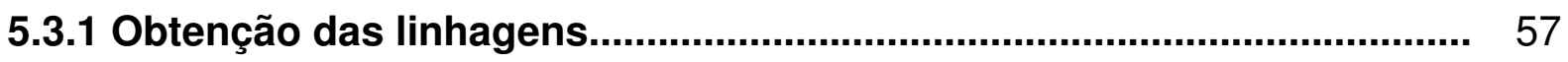

5.3.2 Crescimento de isolados utilizando diferentes fontes de carbono........ 57

5.4 Pré tratamento do efluente industrial (Teste A)....................................... 70

5.4.1 Resultados dos ensaios físico-químicos............................................... 70

5.4.2 Resultados dos ensaios de ecotoxicidade aguda................................. 74

5.5 Bioaumentação no reator biológico sem pré tratamento do efluente industrial (Teste B)................................................................................... 77

5.5.1 Resultados dos ensaios físico-químicos............................................ 77

5.5.2 Resultados dos ensaios de ecotoxicidade aguda.................................... 79

5.6 Caracterização dos isolados............................................................... 92

5.6.1 Caracterização fenotípica..................................................................... 92

5.6.2 Caracterização molecular.................................................................... 94

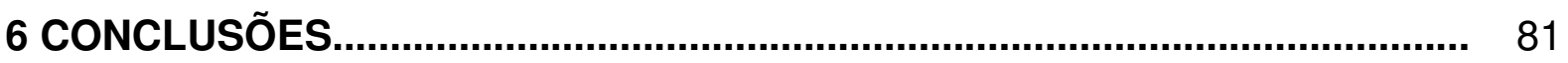

REFERENCIAS BIBLIOGRÁFICAS............................................................. 82 


\section{INTRODUÇÃO}

O desenvolvimento econômico-social de uma determinada região está intrinsecamente ligado à necessidade de aumento na produção industrial. Nos últimos anos, em virtude das demandas de mercado, têm se observado uma flexibilização nos processos industriais, para que novos insumos sejam empregados. No entanto, não se nota a mesma intensidade no aprimoramento de tecnologias para sanear os resíduos decorrentes desse fenômeno, antes que atinjam os ecossistemas. Às indústrias químicas, é atribuído um papel de grande responsabilidade sobre os resíduos que geram, afinal constituem o segmento industrial que praticamente gera os efluentes mais perigosos ao meio ambiente. Geralmente, os efluentes industriais possuem concentrações consideráveis de poluentes, tanto orgânicos quanto inorgânicos, que podem interferir nos processos biológicos de tratamento, desde uma perturbação temporária até sua inibição total.

O lançamento de efluentes industriais na rede pública coletora de esgotos seria uma alternativa bastante satisfatória se as estações de tratamento receptoras possuíssem capacidade de reduzir ou eliminar totalmente os poluentes presentes, muitos dos quais perigosos; no entanto, a maioria das estações convencionais biológicas não foi projetada para esse fim (MORITA e SAPIA, 2003). Felizmente, nos últimos anos, algumas alternativas de pré-tratamento têm sido propostas para efluentes de diferentes segmentos industriais (SPOSITO, 2006).

Quando uma estação de tratamento recebe efluente contendo compostos inibitórios ao processo, a falta de tecnologias específicas para restabelecer as condições operacionais pode sujeitar a planta a autuações por parte dos órgãos de fiscalização ambiental, uma vez que na maioria dos casos a instalação deixa de cumprir seu objetivo primário: remover matéria orgânica e em alguns casos, nutrientes.

A crescente incorporação de práticas de qualidade voltadas para a preservação do meio ambiente, como a ISO 14.000 e Produção Mais Limpa, tem motivado, nos últimos anos, a busca de novas tecnologias que permitam às indústrias gerar menos resíduos e tratá-los antes de serem lançados no meio ambiente. O pré-tratamento biológico é uma das alternativas possíveis para efluentes industriais, uma vez que os microrganismos, agindo de forma isolada ou 
em conjunto, podem transformar parcial ou completamente um determinado composto tóxico e seus intermediários. Por essa razão o presente trabalho propõe o uso da tecnologia da bioaumentação como uma alternativa adicional às tecnologias já existentes para o pré-tratamento de efluentes não-domésticos, através da adição de microrganismos com alto desempenho de degradação de compostos orgânicos reconhecidamente tóxicos, visando a redução da perturbação da microbiota em um sistema de lodos ativados e a conseqüente redução da toxicidade no efluente final. 


\section{REVISÃO DA LITERATURA}

\subsection{Tratamento de efluentes por sistema de lodos ativados}

O sistema de lodos ativados baseia-se na depuração biológica aeróbia da matéria orgânica. Esse sistema foi desenvolvido ao acaso no início do século $X X$, por dois pesquisadores que notaram que a simples aeração de águas residuárias resultava na remoção de material orgânico, ao passo que simultaneamente formavam-se flocos macroscópicos de microrganismos que podiam ser facilmente removidos por decantação simples, obtendo-se assim, um lodo biológico. A mistura desse lodo biológico com outra batelada de água residuária resultava em uma aceleração do processo de depuração de matéria orgânica, e esse sistema ficou então conhecido como "lodo ativado" (MARAIS e VAN HAANDEL, 1999).

Inicialmente operado em batelada, o sistema de lodo ativado atualmente pode ser operado em sistema de alimentação contínua, com a introdução de um tanque de sedimentação após o tanque de aeração. No tanque de sedimentação ocorre a separação do liquido, que é o efluente final tratado, do lodo biológico, que é retornado para o tanque de aeração para que os microrganismos presentes possam depurar o esgoto afluente ao tanque de aeração, rico em matéria orgânica (MARAIS e VAN HAANDEL, 1999). A Figura 1 mostra as unidades constituintes de um sistema de lodo ativado convencional.

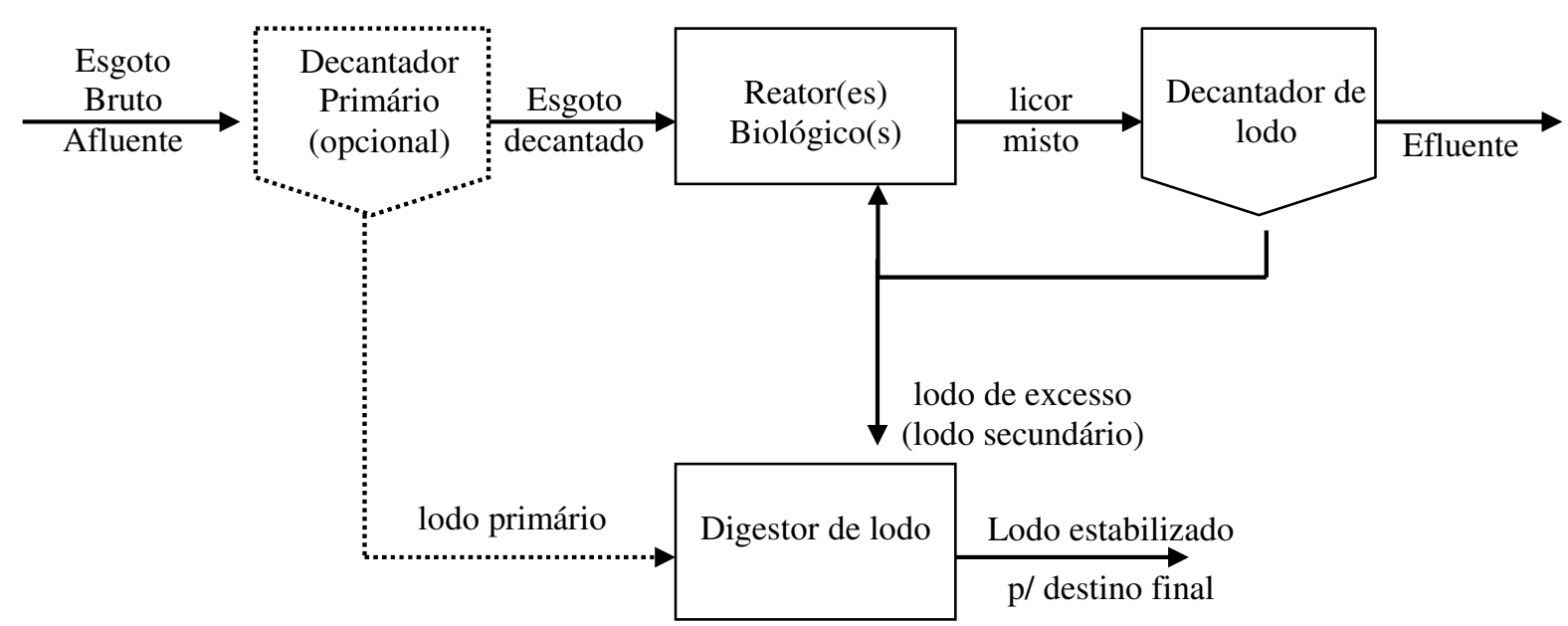

Figura 1 - Representação esquemática das unidades que compõem o sistema de lodos ativados. Fonte: Marais e Van Haandel (1999) - Adaptado. 
O sistema de lodos ativados possui diversas variações, podendo ser de aeração prolongada, batelada seqüencial ou não seqüencial e até mesmo um sistema convencional pode ter uma concepção de engenharia diferenciada para atendimento a exigências de processo e/ou ambientais (EPA, 2008; METCALF e EDDY, 2003).

A composição microbiana de um sistema de lodos ativados é um fator determinante na eficiência do processo de tratamento de esgotos. Interferências nessa composição implicam diretamente na redução da capacidade depurativa de uma planta de tratamento, além disso, boa parte das estratégias operacionais e mesmo a definição de novas tecnologias visam sempre manter condições de homeostase na microbiota. Essa população microbiana é composta por basicamente por bactérias, fungos, protozoários e micrometazoários (CETESB, 2000), sendo que as bactérias constituem o grupo mais importante do sistema do ponto de vista funcional, pois são os organismos responsáveis por praticamente toda a depuração biológica da matéria orgânica poluidora presente no esgoto. Os protozoários são o segundo grupo mais numeroso e atuam como polidores do efluente, consumindo bactérias dispersas que não floculam e flocos biológicos de partículas que não sedimentam, entretanto, possuem papel fundamental como indicadores das condições de processo e qualidade do efluente final (MADONI et al., 1993; CUTOLO, 1996; CETESB, 2000).

Em relação à composição bacteriana, estudos realizados em alguns países há pelo menos três décadas apontam os gêneros predominantes em sistemas de lodos ativados que tratam esgoto basicamente doméstico: Pseudomonas, Flavobacterium, Alcaligenes, Acinetobacter e Zooglea (BENEDICT e CARLSON, 1971; WITTAHAUER, 1980; ADAMSE et. al, 1984; HAMER, 1997). Outros pesquisadores que investigaram a composição microbiológica de sistemas de lodos ativados também demonstraram a presença de organismos dos gêneros Pseudomonas e Acinetobacter, além do gênero Enterobacteriaceae (BUSSE e SEILER ${ }^{1}$, 1978 apud HAMER, 1997; KAPPESSER ${ }^{2}$ et al., 1989 apud HAMER, 1997), ao passo que sob condições de restrição de oxigênio as espécies dominantes

\footnotetext{
${ }^{1}$ BUSSE, M.; SEILER, H. Floraanalyse in biolozischen K1 ranlangen und deren aussage. Z. Vasser-AbwasserForsch, v. 11, p. 111-111, 1978.

2 KAPPESSER, S.; KUTZNER, H. J.; RUDE, E. Microbiological studies of selected bacterial cultures for aerobic treatment of wastewater. Proc. Dechema Biotecnol. Conf., v. 3B, p. 855-858, 1989.
} 
pertenciam aos gêneros Acinetobacter, Pseudomonas, Aeromonas e Flavobacterium (AUTHEUNISSE e KOENE, 1987). Um dos primeiros estudos a determinar a composição bacteriana em um sistema de lodos ativados estável que recebia contribuição de indústria química foi realizado por Blaim et al., (1984), que demonstraram nesse sistema a predominância dos gêneros Alcaligenes e Pseudomonas.

Ao longo da última década, a biotecnologia tem provido muitas ferramentas para identificação da microbiota de sistemas de lodos ativados, muitas das quais sem a necessidade de cultivo prévio (AMANN et al., 1995, 1997). Estudos realizados na década de 90 apontaram a predominância da subclasse beta de Proteobacteria. Esse resultado foi possível graças à utilização de técnicas de identificação in situ, pois membros desse grupo são subestimados por técnicas tradicionais de cultivo, ao passo que membros da classe gama, principalmente do gênero Acinetobacter são superestimados (AMANN et al., 1993, 1994). Tal fato demonstra que a aplicação de técnicas mais recentes confere maior confiabilidade aos trabalhos. Manz et al. (1994) utilizaram sondas especificas de determinados grupos microbianos para demonstrar as diferenças na estrutura das comunidades microbianas entre duas estações de tratamento de efluentes da Alemanha, sendo uma predominantemente doméstica e outra com contribuição de esgoto industrial.

No Brasil, há poucos estudos de caracterização microbiológica de uma estação de tratamento de efluentes. Uma compilação de alguns estudos em um livro sobre Microbiologia de Lodos Ativados editado pela Cia. de Tecnologia de Saneamento Ambiental do Estado de São Paulo - CETESB (CETESB, 2000) demonstra os gêneros bacterianos mais freqüentes em estações de tratamento de esgotos do Brasil: Pseudomonas, Zooglea, Schromobacter, Flavobacterium, Nocardia, Bdellovibrio, Mycobacterium, Klebsiella e bactérias nitrificantes como Nitrosomonas e Nitrobacter.

\subsection{Efluentes não-domésticos}

Quando um determinado recurso hídrico é destinado para fins comerciais e industriais, geralmente carregam compostos acentuadamente nocivos e com grande potencial de causar danos à saúde de operadores em estações de tratamento, corrosão e/ou incrustação às redes coletoras de esgoto, alem de perturbação da 
microbiota responsável pela eficiência dos processos biológicos de tratamento. São, por essas razões, denominados efluentes não-domésticos (END) (MORITA e SAPIA, 2003, 2003, Delatorre Jr. e Morita, 2007).

Muitas vezes, o limite que divide um efluente doméstico do não-doméstico é muito tênue, como no caso de determinados efluentes de shopping centers, cuja composição deveria ser predominantemente doméstica, mas quando existem no estabelecimento lojas prestadoras de serviços de revelação de filmes, por exemplo, diversos compostos orgânicos de elevada toxicidade são lançados em seu efluente, cuja caracterização não mais se enquadra à de efluente doméstico. Uma avaliação desse tipo de efluente foi feita na cidade de Porto Alegre por Hocever e Rodrigues (2002), que resultou na comprovação de sua elevada toxicidade, tanto aguda quanto crônica, para organismos aquáticos. Os efluentes hospitalares também são objeto de preocupação, uma vez que podem ser de cinco a quinze vezes mais tóxicos do que efluentes domésticos comuns (BOILLOT et al, 2007), além do fato de geralmente não sofrerem nenhum tipo de pré-tratamento antes do seu lançamento na rede publica coletora de esgotos. Essa toxicidade deve-se principalmente à presença de diversos químicos genotóxicos, restos de medicamentos, desinfetantes e drogas antineoplásicas, além de restos de excrementos de pacientes que podem conter substâncias com atividade mutagênica (AYUB e ORTOLAN, 2007)

As fontes geradoras de efluentes não domésticos, portanto, são as mais diversas. Por exemplo, as indústrias alimentícias geralmente geram efluentes com baixa toxicidade, constituídos basicamente por proteínas (40 - 60\%), carboidratos (25 - 50\%), óleos e graxas (10\%) e uma infinidade de outros compostos orgânicos em baixa concentração (METCALF e EDDY, 2003). Picos de carga orgânica geralmente compreendem compostos facilmente biodegradáveis, como carboidratos, aminoácidos, peptídeos, proteínas, ácidos voláteis e ácidos graxos (FONG e TAN, 2000). Entretanto, dentre as indústrias alimentícias, destacam-se as de laticínios, que geram efluentes com valores de Demanda Química de Oxigênio que podem chegar a $60.000 \mathrm{mg} \cdot \mathrm{L}^{-1}$ quando há produção de queijos e derivados, além de apresentar teores de lipídeos de até $1.500 \mathrm{mg}^{-1}{ }^{-1}$ (GAVALA et al., 1999). De acordo com Lyberatos (1997), os valores médios reportados em literatura referente a outros parâmetros consideráveis em se tratando de efluentes de indústrias de laticínios são: proteínas, $6.300 \mathrm{mg} \cdot \mathrm{L}^{-1}$ e açucares redutores, 37. $291 \mathrm{mg} \cdot \mathrm{L}^{-1}$, além das presenças 
dos ácidos palmítico, oléico, esteárico e mirístico. Segundo Pereira ${ }^{3}$ (2004) apud Castro et al. (2006), efluentes de indústrias de abates de frango possuem concentração similar de ácidos graxos, porém com maior teor de ácido palmítico. Castro et al. (2006) caracterizaram um efluente de uma indústria de derivados lácteos da cidade de Guaratinguetá, Estado de São Paulo, e encontraram valores de lipídeos até oito vezes superiores aos reportados por Lyberatos (1997). A estação de tratamento de efluentes objeto de estudo recebe aproximadamente $120 \mathrm{~m}^{3} / \mathrm{mês}$ (dados de 2008) de efluente oriundo de uma indústria de laticínios.

A indústria de papel e celulose é uma grande consumidora de água, e, portanto, uma grande geradora de efluentes líquidos. Estima-se que no mundo sejam lançados diariamente mais de 62 milhões de metros cúbicos de águas residuárias produzidas na polpação e branqueamento da celulose (SUOMINEN et al., 1999). Uma das etapas na produção do papel é a separação da lignina da celulose por um processo de oxidação que gera diversas moléculas de diferentes tamanhos, muitas das quais com elevada toxicidade. O método denominado Kraft remove até $90 \%$ dessas moléculas, ainda que seja responsável pela geração de efluentes com alta Demanda Bioquímica de Oxigênio, turbidez, cor e sólidos suspensos e baixas concentrações de oxigênio dissolvido. Entretanto, os 10\% restantes tem que ser eliminados nos processos de branqueamento, normalmente realizados com cloro, hidróxido de sódio e peróxido de hidrogênio. Quando sua eliminação é feita por cloração, é comum a presença de diversas estruturas clorofenólicas. No estágio de branqueamento, são eliminadas, ainda, altas concentrações de fragmentos de lignina com alta massa molecular. Dessa forma, os compostos encontrados nos efluentes de indústrias de papel apresentam alta toxicidade e mutagenicidade, sendo mais resistentes à oxidação biológica nos processos de tratamento convencionais (REID e PAICE, 1998; BERTAZZOLI e PELEGRINI, 2002). No sentido de reduzir a presença desses poluentes nos efluentes, algumas indústrias vem substituindo o uso da cloração por processos oxidativos avançados (BARROS e NOZAKI, 2002).

Outro fator a se considerar é o recebimento de chorume em algumas estações de tratamento de esgotos. Por se tratar de um fluído oriundo da

\footnotetext{
${ }^{3}$ PEREIRA, E. B. Tratamento enzimático para remoção de gorduras dos resíduos gerados por indústrias de produtos avícolas. Tese (Doutorado em Engenharia Química) - Departamento de Engenharia Química, Universidade Federal de Santa Catarina, Florianópolis, 2004.
} 
degradação química e microbiológica dos resíduos sólidos em aterros sanitários, não provém, portanto, da utilização direta da água pelo homem. Contudo, o chorume exibe características peculiares de uma matriz extremamente complexa, podendo possuir em sua composição compostos orgânicos como ácidos orgânicos, substâncias húmicas, solventes, alcoóis, fenóis, compostos aromáticos e pesticidas, além de metais potencialmente tóxicos $(\mathrm{Cd}, \mathrm{Zn}, \mathrm{Cu}, \mathrm{Pb})$, íons como $\mathrm{NH}_{4}{ }^{+}, \mathrm{Ca}^{2+}$, $\mathrm{Mg}^{2+}, \mathrm{K}^{+}, \mathrm{Na}^{+}, \mathrm{Cl}^{-}, \mathrm{S}^{2-}, \mathrm{HCO}_{3}{ }^{-}$entre outros (CLEMENT et al., 1997). A composição do chorume varia em função de tipo de solo utilizado como cobertura dos resíduos, do tipo de lixo depositado, das condições climáticas, da época do ano e da hidrogeologia e idade do aterro (FARQUAR, 1989). Dessa forma, seu valor de DBO equipara-se aos efluentes gerados pelos mais complexos processos industriais, que utilizam insumos que deixam resíduos de características bastante agressivas, possuem grande quantidade de moléculas orgânicas persistentes, altos índices de amônia e alcalinidade e baixa biodegradabilidade (MORAIS et al., 2006). Dessa forma, são considerados, para efeito de recebimento em ETE's, efluentes não domésticos.

No Estado de São Paulo, o lançamento de efluentes não-domésticos na rede pública coletora de esgotos está condicionado ao atendimento do Artigo 19-A do Decreto Estadual 8.468 de 8 de setembro de 1976. No entanto, essa Legislação estabelece limites para diversos parâmetros sem levar em consideração a diluição das diferentes substâncias nos interceptores de esgoto. Dessa forma, é possível que uma indústria que atenda aos requisitos da Legislação possa causar danos ao sistema de coleta, inibição no processo de tratamento ou na geração de efluentes nocivos ao meio ambiente. Alguns estudos tem sugerido metodologias e critérios para recebimento de efluentes não domésticos em estações de tratamento de esgotos (SAMPAIO et al., 1999; MORITA e SAPIA, 2003; SPOSITO, 2006).

\subsubsection{Efluentes de indústrias químicas}

Nos diferentes tipos de processos produtivos empregados pelas indústrias químicas são formados efluentes altamente complexos, que podem conter substâncias comprovadamente tóxicas, como compostos fenólicos, herbicidas, pesticidas, hidrocarbonetos aromáticos polinucleares, entre outros (COSTA et al., 2003), além do fato de muitas vezes apresentarem alta salinidade (MELCHIOR e 
PELEGRINI, 2005; LEFEBVRE e MOLLETTA, 2006), alta temperatura e alta toxicidade. Delatorre Jr. e Morita (2007) avaliaram a eficácia dos critérios de recebimento de efluentes não-domésticos no sistema público de coleta de esgotos. Nesse trabalho, foram apontados os riscos potenciais e reais de incrustação, corrosão e explosividade oferecidos por determinados tipos de efluentes às redes coletoras de esgoto. A presença de poluentes perigosos no efluente pode causar efeitos imensuráveis, pois muitas vezes, passam incólumes pelas estações de tratamento de efluentes alcançando os corpos receptores, aonde podem causar danos à vida aquática e ao homem (MORITA e SAPIA, 2003).

Os efluentes oriundos dos mais diversos seguimentos das indústrias químicas ao redor do mundo apresentam características muito distintas. Podem conter compostos explosivos, como o 2,4,6-trinitrotolueno (RODRIGUES et al., 2007), que além de ser também tóxico e mutagênico, sua alta recalcitrância inviabiliza, pelo menos até onde se conhece, qualquer tipo de tratamento biológico. Efluentes de indústrias produtoras de resinas são caracterizados por elevada matéria orgânica e compostos nitrogenados, sendo o primeiro na forma de formaldeído e o segundo na forma de uréia (EIROA et al., 2006), o que exige para seu completo tratamento a incorporação de diferentes metodologias e tecnologias no processo tradicional de sistemas de lodos ativados (CHENG et al., 1996).

Outro segmento industrial químico que é responsável pela geração de uma quantidade muito grande de resíduos com baixos níveis de degradação e, consequentemente, dificuldade de tratamento e disposição final, é a indústria têxtil (DELLAMATRICE, 2005). O efluente da indústria têxtil e caracterizado por apresentar elevados índices de cor, sendo importante ressaltar que atualmente cerca de 8.000 produtos químicos são utilizados como corantes (BANAT ${ }^{4}$ et al., 1996 apud Dellamatrice, 2005). Eles contem, além de elevada concentração de corantes, outras substâncias utilizadas durante o processo de coloração, tais como gomas, hidróxido de sódio, detergentes, sabões, antiespumantes, cloro, formóis, emulsões, dispersantes, óleos, resinas, etc. Seu pH é altamente alcalino, variando entre 8 e 11, e apresentam elevada carga orgânica, uma vez que o teor de sólidos totais situa-se na faixa entre 1.000 a $1.600 \mathrm{mg} \cdot \mathrm{L}^{-1}$ e o teor de sólidos em suspensão totais entre 30

\footnotetext{
4 BANAT, I. M.; MARCHANT, R.; NIGAM, P.; SINGH, D. Microbial decolorization of textile-dye-containing effluents: a review. Bioresource Technology, v. 58, p. 217-227, 1996.
} 
a $50 \mathrm{mg} \cdot \mathrm{L}^{-1}$ (BRAILE e CAVALCANTI, 2003). As refinarias de petróleo também representam um seguimento industrial de grande relevância do ponto de vista de geração de resíduos sólidos e líquidos. A indústria petroquímica apresenta muita versatilidade de processos, os produtos das refinarias podem ser convertidos em outros de grande valor comercial, como resinas, borrachas sintéticas, agroquímicos e produtos de limpeza (BELLO et al., 2005). Fenóis e seus derivados estão sempre presentes nos efluentes dessas indústrias, juntamente com elevada concentração de hidrocarbonetos aromáticos polinucleares e outros compostos complexos com elevado peso molecular, o que pode tornar esses efluentes altamente recalcitrantes (GABARDO et al., 1998).

Os efluentes gerados pela indústria farmacêutica vem gerando grande preocupação por parte de ambientalistas em virtude da cada vez mais freqüente presença de fármacos em efluentes de estações de tratamento de esgoto e águas naturais (BILA e DEZOTTI, 2003). São caracterizados por uma fração orgânica biodegradável e compostos refratários, que normalmente não são removidos por processos de tratamento convencionais. Os efluentes da produção de antibióticos, por exemplo, apresentam biodegradabilidade muito baixa, além de serem tóxicos para organismos aquáticos e promoverem o desenvolvimento de cepas bacterianas multiresistentes (ALMEIDA et al., 2004).

\subsubsection{Inibição sobre o processo de lodos ativados}

De acordo com Sposito (2006), efluentes industriais podem ser responsáveis por diversos impactos ao sistema de coleta, transporte e tratamento de esgotos, como por exemplo:

- Risco de incrustação e corrosão a tubulações do sistema de coleta e transporte;

- Inviabilidade da produção de água de reuso e disposição do lodo gerado em agricultura, indústria ou aterros, em virtude dos efeitos na qualidade dos produtos gerados;

- Geração de problemas de saúde ocupacional em operadores da estação de tratamento; 
- Poluição atmosférica, que pode ocorrer em função da volatilização de compostos tóxicos;

- Inibição da atividade da biomassa da estação de tratamento, o que pode levar à queda no desempenho operacional e consequentemente, à geração de efluentes tóxicos ao ecossistema.

O grau de inibição que cada efluente oriundo de fontes industriais pode conferir a um sistema de tratamento apresenta grande variabilidade, sendo muito particular em alguns casos. Costa et al. (1997) utilizaram lodos ativados provenientes da estação de tratamento de esgotos de Barueri, São Paulo, para demonstrar que o fenol interfere no processo de nitrificação, porém exerce pouco efeito sobre a remoção de matéria orgânica. Similarmente, é possível que, ao se utilizar lodos de outra estação, o mesmo composto químico possa impactar outros processos e não provocar efeitos sobre a nitrificação.

Quando um sistema de lodos ativados está adaptado ou possui condições de depurar os compostos orgânicos tóxicos que entram na estação de tratamento, não se observam efeitos como os citados anteriormente (Sposito, 2006). Segundo Melchior e Pelegrini (2005), determinadas substâncias químicas podem funcionar ora como nutriente, ora como agente bacteriostático ou bactericida. Diversos estudos têm demonstrado o destino de muitos poluentes ao serem introduzidos no sistema de lodos ativados: adsorção no lodo, biodegradação, volatilização ou escape pelo efluente final (BERG et al., 1996; PARAIBA e SAITO, 2005). No caso das substâncias que passam incólumes pelo sistema de tratamento, são ditas refratárias (SPOSITO, 2006), podendo consistir desde compostos orgânicos simples até complexas moléculas sintetizadas industrialmente, como por exemplo, os fármacos (BILA e DEZOTTI, 2003).

Diversas substâncias químicas utilizadas para lavagens e desinfecções de unidades industriais podem conferir elevada toxicidade às estações de tratamento de efluentes, principalmente aos processos anaeróbios, devido à baixa faixa de tolerância à toxicidade de bactérias metanogênicas. Young (2008) demonstrou através de testes de atividade metanogênica e respirometria o impacto de compostos quaternários de amônio e desinfetantes clorados sobre processos aeróbio e anaeróbio, resultando na queda do desempenho de uma planta de 
tratamento, medida por diminuição na capacidade de remoção de DBO na fase aeróbia e produção de gás metano na fase anaeróbia. Em estudo realizado recentemente, Drakides e Lay-Son (2008) demonstraram o efeito inibitório da amônia livre $\left(\mathrm{NH}_{3}\right)$, formada a partir do íon amônio $\left(\mathrm{NH}_{4}^{+}\right)$, sobre os processos de nitrificação e biodegradação do tiocianato. De acordo com esse estudo, determinadas concentrações de $\mathrm{NH}_{3}$ e poluentes inibem a degradação das principais moléculas. Bracklow et. al (2008) avaliaram o impacto de surfactantes sintéticos na concentração de $50 \mathrm{mg} / \mathrm{L}$ - valor muito comum em efluentes de muitas indústrias químicas, e observaram redução na taxa de crescimento de bactérias heterotróficas totais e também na sua afinidade pela fonte de carbono. Efluentes industriais contendo quantidades significativas de sulfeto também podem exercer efeito inibitório sobre a biomassa de um sistema de lodos ativados, conforme demonstrado por Arima et. al (2002).

Os lipídeos presentes nos efluentes de laticínios podem ocasionar flotação da biomassa e má formação de grânulos de lodo em reatores anaeróbicos de fluxo ascendente (GAVALA et al., 1999), toxicidade a microrganismos acetogênicos e metanogênicos e formação de espumas devido ao acúmulo de ácidos graxos não biodegradados. Devido a esse fato, a digestão anaeróbia destes rejeitos torna-se um processo lento (CASTRO et al.,2006). Processos como lodos ativados não são eficientes para o tratamento desse tipo de efluente, pois é muito suscetível a problemas de intumescimento filamentoso do lodo - fenômeno denominado bulking (MAYER et al., 2000).

O processo de nitrificação é um dos mais sensíveis que ocorrem em estações de tratamento de esgotos, comparando-se com os demais processos biológicos de remoção de matéria orgânica, pois dependem de condições específicas de temperatura, $\mathrm{pH}$ e disponibilidade de oxigênio no meio (HOCKENBURY e GRADY ${ }^{5}$, 1977 apud BAEYENS et al., 2003; VANROLLEGHEM et al., 1996). Muitas espécies de inibidores podem estar presentes nos esgotos, principalmente na forma de metais pesados e compostos orgânicos. Os metais exercem efeitos duais sobre a microbiota responsável pela nitrificação, pois podem agir como elementos traço requeridos para o crescimento das bactérias ao passo que também podem ser

\footnotetext{
5 HOCKENBURY, M. R.; GRADY, C. P. L. Inhibition of nitrification - effects of selected organic compounds. Journal Water Pollution Control Federation, v. 49, n. 5, p. 768-777, 1977.
} 
inibidores. Segundo Baeyens et al. (2003), a produção de nitrito e nitrato decrescem à medida que a concentração de metais pesados aumenta. Nesse trabalho, observou-se que o processo de nitrificação como um todo sofreu uma inibição de $97 \%$ quando a concentração de íons zinco atingiu $1,2 \mathrm{mgZn}^{2+} . \mathrm{L}^{-1}$. Em relação aos compostos orgânicos, o mesmo autor afirma que tricloroeteno e clorobenzeno são considerados os compostos que exercem as maiores inibições sobre a nitrificação, seguidos de etilbenzeno e fenóis. No caso da estação de tratamento de esgotos objeto de estudo, acredita-se que o fenol exerça pouca influência, uma vez que diversos testes já confirmaram a adaptação da biomassa a esse composto (dados não publicados).

\subsection{Ensaios ecotoxicológicos}

Os testes de ecotoxicidade aquática são ferramentas empregadas no estudo dos efeitos dos agentes tóxicos sobre organismos aquáticos e baseiam-se na premissa de que a resposta dos organismos vivos depende da dose do agente a que foram submetidos (RAND e PETROCELLI, 1985). São largamente empregados na avaliação da qualidade das águas e do potencial ecotoxicológico de efluentes, uma vez que ensaios físicos e químicos tradicionalmente adotados por laboratórios de monitoramento ambiental, como Demanda Química e Bioquímica de Oxigênio, metais pesados, compostos orgânicos e inorgânicos e sólidos, muitas vezes não são suficientes para demonstrar o real efeito de efluentes sobre o ecossistema aquático, mesmo que tais parâmetros estejam em acordo com a Legislação vigente (BOTTA et al., 2008). No Brasil, a partir de 17 de março de 2005, ensaios ecotoxicológicos passaram a ser exigidos por órgãos de fiscalização ambiental como requisito para lançamento de efluentes em corpos receptores, conforme os $\S 1$ e 2 do Artigo 34 da Resolução CONAMA 357, que estabelece o efluente não deverá causar ou possuir potencial para causar efeitos tóxicos aos organismos aquáticos no corpo receptor, e os critérios de toxicidade devem se basear em resultados de ensaios ecotoxicológicos padronizados utilizando organismos aquáticos. No Estado de São Paulo, os parâmetros e limites estabelecidos para o lançamento de efluentes líquidos constam no regulamento da Lei 997, de 31 de maio de 1976, aprovado pelo Decreto 8.468 de 8 de setembro de 1976. Esta lei institui o Sistema de Prevenção e Controle da Poluição do Meio Ambiente e proíbe o lançamento ou liberação de 
poluentes nas águas, no ar ou no solo, que os tornem impróprios ou nocivos à saúde e bem estar público e danosos à fauna e à flora. A Resolução da Secretaria do Meio Ambiente - SMA-3, de 22 de fevereiro de 2000, acrescenta a Lei 997/76, determinando que os efluentes lançados não deverão causar ou possuir potencial para causar efeitos tóxicos aos organismos aquáticos no corpo receptor, de acordo com as normas que fixam a toxicidade permissível.

É recomendável que a avaliação ecotoxicológica de um determinado efluente ou substância seja realizada utilizando-se organismos pertencentes a diferentes níveis tróficos (ARAUJO et al., 1990; RIBO, 1997; BOTTA et al., 2008), pois as respostas dos organismos aos agentes causadores da toxicidade podem apresentar diferenças significativas. Normalmente, adota-se mais de um organismo-teste, para que aquele que apresenta maior sensibilidade possa ser utilizado como o padrão mínimo aceitável em termos de toxicidade, garantindo mais segurança ao ecossistema aquático (ARAUJO et al., 1990). Portanto, o efeito verificado em um determinado organismo não pode ser extrapolado para outros.
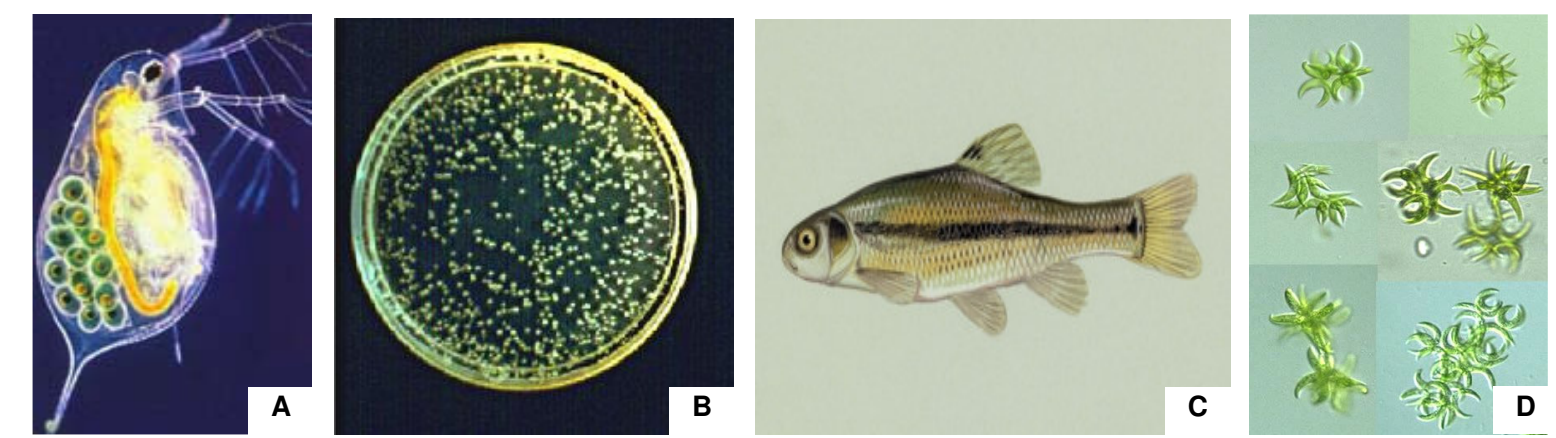

Figura 2 - Alguns organismos utilizados em ensaios ecotoxicologicos: A) microcrustáceo Daphnia similis Claus, 1876 (Cladocera, Crustacea); B) bactéria luminescente Vibrio fischeri; C) peixe Pimephales promelas; D) alga Selenastrum capricornutum.

Conforme se pode observar na Figura 2, o espectro de organismos comumente empregados nos testes ecotoxicológicos é muito grande, desde bactérias luminescentes, da espécie Vibrio fischeri até vertebrados, como o peixe Pimephales promelas, passando por algas e invertebrados, como moluscos e crustáceos, sendo nesse último filo muito comum a adoção de espécies do gênero Daphnia e Ceriodaphnia (LEITE e MORITA, 1999). A rigor, qualquer espécie aquática pode ser adotada para testes de toxicidade, entretanto, os organismos selecionados devem possuir as seguintes características comuns: seletividade constante e elevada aos contaminantes, elevadas disponibilidade e abundância, 
uniformidade e estabilidade genética nas populações, representatividade de seu nível trófico, significado ambiental em relação à área de estudo, ampla distribuição e importância comercial e facilidade de cultivo e de adaptação às condições de laboratório. Além disso, organismos cuja fisiologia, genética e comportamento sejam bem conhecidos, facilitam a interpretação dos resultados (MCCARTY et al., 1995; APHA, AWWA, WEF, 1998; BAEZ et al., 2004). No Brasil, o órgão responsável pelo desenvolvimento de protocolos de testes de toxicidade é a Associação Brasileira de Normas Técnicas (ABNT). A Companhia de Tecnologia de Saneamento Ambiental do Estado de São Paulo (CETESB) também tem padronizado testes de toxicidade no âmbito estadual. Na Tabela 1, a seguir, são apresentadas as principais normas brasileiras referentes a testes de toxicidade aquática para organismos pertencentes a diferentes grupos taxonômicos.

Tabela 1 - Testes de toxicidade padronizados pela ABNT e CETESB.

\begin{tabular}{llll}
\hline Organismo & Efeito & Espécie & Normas brasileiras \\
\hline Bactéria & Agudo & Vibrio fischeri & CETESB, L5.227 \\
\hline Bactéria & Agudo & Spirillum volutans & CETESB, L5.228 \\
\hline \multirow{3}{*}{ Alga } & Chlorella vulgaris, & \\
& Crônico & $\begin{array}{l}\text { Scenedesmus subspicatus, } \\
\text { Pseudokirchneriella }\end{array}$ & CETESB, L5.020 e \\
& & subcapitata & ABNT, NBR 12648 \\
Microcrustáceo & Agudo & Daphnia similis, Daphnia & CETESB, L5.018 e \\
Microcrustáceo & Agudo & Artemia salina & ABNT, NBR 12713 \\
\hline \multirow{2}{*}{ Microcrustáceo } & Crônico & Ceriodaphnia dúbia, & CETESB, L5.021 \\
& & Ceriodaphnia silestrii & CETESB L5.022 e \\
\hline Peixe & Agudo & Danio rerio, Pimephales & ABNT, NBR 13373 \\
\hline
\end{tabular}

Fonte: Botta et al. (2008) - Adaptado.

Há basicamente dois grandes grupos de efeitos através dos quais a toxicidade a um sistema aquático se pronuncia: aguda e crônica. A toxicidade aguda é o efeito prontamente observável quando a fauna aquática é exposta ao agente tóxico por um curto período de tempo, geralmente entre 24 e 96 horas. Os 
resultados são expressos em CE50, que é a concentração (\%) do agente tóxico, que causa efeito de imobilidade ou outro efeito que não seja a letalidade, por exemplo, a reprodução; ou CL50, que é a concentração que causa morte, em ambos os casos a $50 \%$ dos organismos expostos ao agente tóxico. Esse efeito mensurável em $50 \%$ da população exposta à substância ou efluente a ser testado apresenta suficiente grau de confiabilidade e são mais significativos para serem extrapolados para uma população. Um exemplo de efeito agudo é o lançamento de efluentes industriais não tratados em corpos d'água receptores (CETESB, 1986; MCCARTY et al., 1995; BAEZ et al., 2004; BOTTA et al., 2008). A toxicidade crônica refere-se a efeitos decorrentes da exposição prolongada - aproximadamente 21 dias - ao agente tóxico. Tais efeitos pronunciam-se por meio da interferência em processos biológicos dependentes de séries de reações enzimáticas e processos fisiológicos, como inibição da fertilização, crescimento e reprodução (CETESB, 1986). Os resultados dos ensaios nos quais foram avaliadas substâncias químicas específicas são geralmente expressos por $\mathrm{mg} \cdot \mathrm{L}^{-1}$, ao passo que para efluentes, os valores são expressos em percentual. Perez et al . (1997) apud Botta et al. (2008) avaliaram a toxicidade aguda de diferentes efluentes industriais e encontraram valores muito diversos, conforme apresentado na Tabela 2, a seguir:

Tabela 2 - Toxicidades agudas de diferentes efluentes industriais para Daphnia magna após 48h de exposição.

\begin{tabular}{clcc}
\hline Efluente & \multicolumn{1}{c}{ Origem do Efluente } & CL50 (\%) & $\begin{array}{c}\text { CL50 } \\
\text { (U.T.) }\end{array}$ \\
\hline 1 & Hospital & $0,4 \pm 0,2$ & 250,0 \\
2 & Hospital & $33,2 \pm 6,6$ & 3,0 \\
3 & $\begin{array}{l}\text { Fabricante de materiais } \\
\text { para escritórios e escolas }\end{array}$ & $70,8 \pm 15,2$ & 1,4 \\
4 & Fabricante de peças para & $54,5 \pm 5,3$ & 1,8 \\
& automóveis & \\
5 & Fabricante de produtos de & $51,0 \pm 11,4$ & 2,0 \\
& higiene & $49,1 \pm 10,3$ & 2,0 \\
7 & Companhia farmacêutica & $0,2 \pm 0,1$ & 500,0 \\
\hline
\end{tabular}

Fonte: Botta et al. (2008) - Adaptado.

\footnotetext{
${ }^{6}$ PEREZ, F. R.; RODRIGUES, R.; VILLEGAS-NAVARRO, A. Determination of LC ${ }_{50}$ from Daphnia magna in treated industrial waste waters and non-treated hospital effluents. Environment International, v. 23, n. 4, p. 535540, 1997.
} 
Os resultados dos ensaios de toxicidade aguda e crônica, expressos como CL50 ou CE50 representam uma relação inversa à toxicidade, ou seja, quanto menor o valor, maior é a toxicidade da substância ou do efluente. Para facilitar a comparação e representar tais valores com uma correlação direta ao grau de toxicidade conferido pelo agente, tais resultados podem ser transformados em Unidades Tóxicas (UT) aguda ou crônica, através da equação a seguir:

$$
\text { UT }=100 / \text { CE50 ou UT }=100 / \text { CL50 }
$$

A estação de tratamento de esgotos estudada caracteriza-se por receber, além de esgoto doméstico, uma porção considerável de efluentes industriais, oriundos de estabelecimentos de diferentes seguimentos. Tal característica sujeita a biomassa da planta a sofrer efeitos decorrentes da mistura desses efluentes diversos, são os chamados efeitos aditivos, sinérgicos e antagônicos (APIKYAN et al., 1999; JAMES et al., 2000; BOILLOT et al., 2007; BOTTA, et al., 2008).

O efeito aditivo ocorre quando a soma da toxicidade da mistura é matematicamente igual à soma das toxicidades de todos os seus componentes. Nas situações em que a toxicidade final de uma mistura é superior à soma das toxicidades de seus constituintes, observamos um efeito sinérgico. Efeitos antagônicos também podem ocorrer, nos quais a mistura apresenta toxicidade inferior à toxicidade de seus componentes. Esses efeitos decorrem dos tipos de interações que as diferentes substâncias presentes no meio sofrem. São quatro tipos possíveis: os constituintes da mistura exercem efeito sobre a mesma função fisiológica; interações químicas entre moléculas da mistura afetam a toxicidade de um dos elementos; a absorção, o metabolismo, a distribuição ou a excreção de um constituinte sofre alteração provocada pelos demais elementos presentes e, há uma competição entre os constituintes da mistura pelo mesmo tecido receptor (JAMES et al. $^{7}, 2000$ apud BOTTA et al., 2008).

Além dos ensaios ecotoxicológicos utilizando organismos-teste, Leite e Morita (1999) descreveram inúmeros outros testes que podem ser realizados para predizer os efeitos causados por despejos industriais em sistemas de tratamento de esgotos:

7 JAMES, R. C.; ROBERTS, S. M.; WILLIANS, P. L. Principles of Toxicology: Environmental and Industrial Applications. New York: John Wiley \& Sons Ed., 2000. 
testes enzimáticos, bioquímicos, taxa de crescimento microbiano, inibição do consumo de substrato, etc.

\subsection{Tratamento biológico de efluentes industriais por bioaumentação}

Bioaumentação consiste na adição de organismos em um determinado ecossistema para otimizar um determinado processo biológico (BOUCHEZ et al., 2000), um exemplo é a remoção biológica acelerada de compostos químicos, geralmente tóxicos e indesejáveis, de um determinado local contaminado, através da adição de uma população microbiana. Os agentes responsáveis são, via de regra, microrganismos oriundos do próprio local que se pretende remediar ou microrganismos isolados previamente de outros sítios que são posteriormente inoculados no local em questão. As espécies microbianas podem ser introduzidas isoladamente ou em consórcio, que é uma mistura de diferentes linhagens (BOON et al., 2000, 2003; JANSSEN et al., 2005; AGATHOS e FANTROUSSI, 2005; BOUCHEZ et al., 2000; THOMPSON et al., 2005). Outra técnica que pode ser utilizada para atingir objetivos similares é a bioestimulação, que ao contrário da bioaumentação, não é caracterizada pela adição de linhagens microbianas no meio, mas sim de nutrientes ou aceptores de elétrons, que estimulam o crescimento dos organismos já existentes no local (AGHATOS e FANTROUSSI, 2005). Existe caso em que ambas tecnologias foram aplicadas em conjunto (BURNS et al., 2004).

De acordo com Gentry et al., (2004) já foram relatadas diversas experiências de aplicação de diferentes técnicas de bioaumentação. Dentre as opções já avaliadas para intensificar a persistência e a atividade dos microrganismos adicionados estão: bioaumentação com células encapsuladas em um carregador; bioaumentação com genes, cujo objetivo é a transferência horizontal de genes por parte dos inoculados para os microrganismos previamente encontrados no local; fitoaumentação, uso de vegetais com potencial de remediação de compostos orgânicos e metais pesados em lagoas e efluentes industriais, nos quais pode-se utilizar inclusive vegetais geneticamente modificados; solo ativado, tecnologia utilizada para remediação de solos cujo princípio é similar ao de lodos ativados, ou seja, utiliza-se um solo que já foi exposto aos poluentes que se pretende degradar e que, portanto, já possui uma população microbiana adaptada, além de condições abióticas adequadas para tanto. 
O uso de organismos geneticamente modificados carregando genes de interesse para biodegradação de poluentes-alvos é outra opção muito promissora (ALVES et al., 2005; FURUKAWA e KIMURA, 1995; MCTAVISH, 2000; KULPA et al., 1995; REINEKE, 1998), embora essa tecnologia ainda seja vista com reserva, pois até o momento, não se verificou em literatura nenhum caso de desenvolvimento de linhagens geneticamente modificadas para uso em sistemas de lodos ativados seguras o suficiente para evitar a dispersão ambiental dos elementos transgênicos que carregam. No Estado de São Paulo, a adoção de linhagens geneticamente modificadas para tratamento de efluentes encontra restrições na Norma CETESB L1.022 (CETESB, 1994). Porém, independente da opção de bioaumentação selecionada, Agathos e Fantrousii (2005) estabelecem os critérios que devem ser considerados para que a tecnologia possa ser satisfatoriamente implementada: 1. a natureza química do poluente que se pretende degradar; 2. a concentração do poluente no meio e sua disponibilidade ao organismo e 3. as características físicoquímicas do ambiente no qual a(s) linhagem(ns) será(ão) introduzida(s). Através da análise da natureza química do composto, é possível determinar se o poluente-alvo trata-se de uma molécula complexa ou uma mistura de compostos que somente podem ser degradados por um consórcio microbiano. Poluentes típicos dessa categoria incluem hidrocarbonetos poliaromáticos, compostos halogenados (tanto alifáticos quanto aromáticos), bifenilas policloradas, compostos organo-nitrogenados, como por exemplo o 2,4,6-trinitrotolueno, compostos organofosforados, pesticidas triazínicos ou herbicidas. Segundo Boon et al. (2000), os experimentos de bioaumentação obtêm bons resultados em laboratório, porém, sob condições naturais, as linhagens inseridas têm que competir com comunidades microbianas já estabelecidas, o que muitas vezes resulta na diminuição das células inoculadas e, portanto, na perda da capacidade degradatativa. O sucesso da bioaumentação depende, além das interferências físico-quimicas, principalmente do resultado das interações ecológicas que a espécie introduzida irá estabelecer no meio. Em 1985, Alexander et al ${ }^{8}$. (1985) apud Boon (2000) já destacavam a predação de espécies bacterianas introduzidas em sistema de lodos ativados por protozoários previamente encontrados no meio, o que posteriormente foi observado através do uso de

\footnotetext{
${ }^{8}$ ALEXANDER, M., GOLDSTEIN, M. G., MALLORY, L. M. Reasons for possible failure of inoculation to enhance biodegradation. Applied and Environmental Microbiology, v. 50, p. 1667-1672, 1985.
} 
técnicas de biologia molecular por Amann et al. (1997). Outro aspecto importante é a presença de outros substratos de fácil degradação que podem atrair a preferência do organismo, em detrimento ao poluente-alvo (BALTZIS et. al, 2000). Recentemente, Lefebvre e Molletta (2006) apresentaram alternativas para remoção de matéria orgânica, nitrogênio e fósforo em efluentes contendo altas concentrações de sais, através da introdução de microrganismos halofílicos, ou seja, que possuem capacidade de crescer em altas concentrações de sais.

A Tabela 3 apresenta alguns casos recentes de aplicação de bioaumentação visando a.degradação de compostos químicos orgânicos em diferentes meios: solo, lodo ativado e aqüífero.

Tabela 3 - Exemplos de estudos recentes de bioaumentação em solo, lodos ativados e aqüífero.

\begin{tabular}{|c|c|c|}
\hline Local & Microrganismo & Poluente \\
\hline \multirow{16}{*}{ Solo } & Pseudomonas sp. linhagem ADP & Atrazina \\
\hline & Agrobacterium radiobacter J14a & Atrazina \\
\hline & Escherichia coli pAtzA & Atrazina \\
\hline & Consórcio degradador de atrazina & Atrazina \\
\hline & Alcaligenes eutrophus TCP & 2,4,6-triclorofenol \\
\hline & Desulfitobacterium frappieri PCP-1 & Pentaclorofenol \\
\hline & Ralstonia eutropha (pJP4) & 2,4 ácido diclorofenoxiacético \\
\hline & Ralstonia eutropha JMP134 & 2,4 ácido diclorofenoxiacético \\
\hline & Pseudomonas sp. linhagem P51 & $1,2,4$ triclorobenzeno \\
\hline & Pseudomonas pseudoalcaligenes & 1,2,4 ácido fenoxibenzóico \\
\hline & POB310 & \\
\hline & Desulfomonile tiedjei & 3-clorobenzoato \\
\hline & $\begin{array}{l}\text { Arthrobacter sp. B1B e Ralstonia } \\
\text { eutrophus } \mathrm{H} 850\end{array}$ & Bifenilas policloradas \\
\hline & Arthrobacter RP17 & Fenantreno \\
\hline & Ralstonia basiliensis RK1 & 2,6-diclorofenol \\
\hline & Consórcio encapsulado & Gasolina \\
\hline \multirow{4}{*}{$\begin{array}{l}\text { Lodo } \\
\text { ativado }\end{array}$} & Comamonas sp. RN7(R503) & Fenol \\
\hline & Comamonas testosteroni 12 & 3-cloroanilina \\
\hline & Candidatus Accumulibacter phosphatis & Fósforo \\
\hline & Desulfitobacterium frappieri PCP-1 & Pentaclorofenol \\
\hline
\end{tabular}




\begin{tabular}{|c|c|c|}
\hline Local & Microrganismo & Poluente \\
\hline \multirow{9}{*}{$\begin{array}{l}\text { Aqüífero / } \\
\text { água } \\
\text { subterrânea }\end{array}$} & Consórcio metanogênico & BTEX \\
\hline & Pseudomonas stutzeri KC & Tetracloreto de carbono \\
\hline & Consórcio contendo Dehalococcoides & Cloroetenos \\
\hline & P. putida GJ31, P. aeruginosa $\mathrm{RH} 01 \mathrm{e}$ & Clorobenzenos \\
\hline & & \\
\hline & P. putida $\mathrm{F} 1 \Delta \mathrm{CC}$ & \\
\hline & $\begin{array}{l}\text { Cultura enriquecida degradadora de } \\
\text { butano }\end{array}$ & 1,1,1-tricloroetano \\
\hline & Hydrogenophaga flava ENV735 & Éter metil tert-butil \\
\hline & $\beta$-proteobacterium linhagem PM1 & Éter metil tert-butil \\
\hline
\end{tabular}

Fonte: Agathos e Fantroussi (2005) - Adaptado.

conclusão

Muitas vezes, a adoção da bioaumentação como estratégia de remediação de efluentes é bastante controversa, sendo que já foram reportados em literatura diversos casos de insucesso (BOUCHEZ et al., 2000, 2000), nos quais o número de organismos adicionados decai rapidamente após sua inoculação. Tais casos devemse, muitas vezes, a fatores bióticos, por exemplo, as interações ecológicas que as linhagens adicionadas sofrem ao serem inoculadas no lodo ativado, como predação por protozoários e/ou bacteriófagos e competição com outras espécies já presentes pelas fontes de carbono e nutrientes disponíveis (GENTRY et al., 2004), e também à fatores abióticos, como variações de temperatura, $\mathrm{pH}$, oxigenação do meio e presença de poluentes potencialmente tóxicos (VAN ELSAS et al., 1997). Diversas ferramentas biotecnológicas têm sido desenvolvidas nos últimos anos para monitorar as cepas microbianas utilizadas em bioaumentação, o que traz boas perspectivas quanto ao uso da tecnologia (AMANN et al., 1995, 1997; KULPA et al., 1995; BOUCHEZ et al., 2000, 2000; AGATHOS et al., 2001; MUNETA et al., 2002). A Tabela 4, a seguir, exemplifica algumas das tecnologias desenvolvidas que permitem a detecção e a atividade dos microrganismos introduzidos. 
Tabela 4 - Métodos para monitoramento da sobrevivência e atividade dos microrganismos utilizados em bioaumentação.

\begin{tabular}{|c|c|c|}
\hline Método & $\begin{array}{l}\text { Parâmetro } \\
\text { medido }\end{array}$ & Vantagens / desvantagens \\
\hline rRNA 16S PCR & Presença & $\begin{array}{l}\text { Simples, custo menor em relação a outros métodos. Não } \\
\text { quantitativo. Os produtos do PCR podem ser analisados } \\
\text { posteriormente por outros métodos para aumentar } \\
\text { especificidade. }\end{array}$ \\
\hline $\begin{array}{l}\text { PCR Transcriptase } \\
\text { reversa }\end{array}$ & Atividade & $\begin{array}{l}\text { Determina a expressão gênica. Pode ser combinado com } \\
\text { PCR em tempo real para ser quantitativo. }\end{array}$ \\
\hline PCR em tempo real & $\begin{array}{l}\text { Presença / } \\
\text { Atividade }\end{array}$ & $\begin{array}{l}\text { Rápido, quantitativo, muito sensível, possibilita detectar } \\
<10^{4} \text { céls. g/ solo. Pode ser combinado com PCR } \\
\text { transcriptase reversa para medir expressão gênica. }\end{array}$ \\
\hline $\begin{array}{l}\text { Hibridização in situ } \\
\text { fluorescente }\end{array}$ & $\begin{array}{l}\text { Presença / } \\
\text { Atividade }\end{array}$ & $\begin{array}{l}\text { Permite visualizar, enumerar e identificar microrganismos } \\
\text { diretamente sem cultivo. Quantitativo. Permite analisar } \\
\text { comunidades complexas utilizando-se sondas simples. }\end{array}$ \\
\hline Microarray & $\begin{array}{l}\text { Presença / } \\
\text { Atividade }\end{array}$ & $\begin{array}{l}\text { Análise simultânea da expressão de mais de } 100 \text { genes. } \\
\text { Menos sensível do que outros métodos. Pode ser } \\
\text { quantitativo. }\end{array}$ \\
\hline Genes repórteres & $\begin{array}{l}\text { Presença / } \\
\text { Atividade }\end{array}$ & $\begin{array}{l}\text { Possibilita visualizar microrganismos in situ. Quantitativo. } \\
\text { Repórteres luminescentes permitem a medição in situ da } \\
\text { expressão de genes. Múltiplos repórteres permitem o } \\
\text { estudo simultâneo de diversos microrganismos. }\end{array}$ \\
\hline
\end{tabular}

Fonte: Gentry et al. (2004) - Adaptado. 


\section{OBJETIVOS}

O presente trabalho tem por objetivo principal avaliar o uso da tecnologia de bioaumentação na redução da toxicidade aguda do efluente final de uma estação de tratamento de esgotos. Para tanto, foram delineados os seguintes objetivos específicos:

- Identificar os poluentes orgânicos presentes em maior concentração em amostra de efluente não-doméstico oriundo de uma indústria química com contribuição significativa para a estação de tratamento de esgotos;

- Isolar linhagens microbianas com capacidade de biodegradação dos poluentes presentes no efluente da indústria química e selecionar as que possuem maior potencial de degradação;

- Verificar a variação da toxicidade do efluente final da estação de tratamento após pré-tratamento do efluente industrial com as linhagens isoladas;

- Caracterizar os isolados fenotípica e genotipicamente, avaliando a diversidade das linhagens. 


\section{MATERIAL E MÉTODOS}

\subsection{Caracterização da estação de tratamento de efluentes - E.T.E.}

A estação de tratamento de efluentes, objeto do presente trabalho, situa-se no município de Suzano, localizado $30 \mathrm{~km}$ à leste da capital do Estado de São Paulo. A estação foi projetada para uma população de 670.000 habitantes e hoje atende aproximadamente 470.000, divididos entre os municípios de Suzano, Mogi das Cruzes, Poá, Itaquaquecetuba e Ferraz de Vasconcelos. A capacidade de tratamento instalada é de 1.500 litros de esgoto por segundo, porém a vazão média tratada atualmente é de $700 \mathrm{~L} / \mathrm{s}$ (SABESP, 2008). O sistema de tratamento adotado na E.T.E. é de lodos ativados mistura completa, com eficiência maior que $90 \%$ na remoção de matéria orgânica, medida em $\mathrm{DBO}_{5,20}$. Aproximadamente $10 \%$ do esgoto recebido na E.T.E. é oriundo de fontes não-domésticas, o qual contribui com $75 \%$ da carga orgânica recebida, medida em DQO. Esse END é recebido de duas formas: através da rede coletora de esgotos e também por caminhões-pipa. A Tabela 5 apresenta os volumes recebidos ( $\mathrm{m}^{3} / \mathrm{mês}$ ) das contribuições via rede e via caminhão-pipa, ao longo de doze meses (SABESP, 2008).

Tabela 5 - Volumes de efluentes domésticos e não-domésticos recebidos via rede e via caminhão na E.T.E. objeto durante o período de junho de 2007 a maio de 2008.

\begin{tabular}{cccccc}
\hline \multirow{2}{*}{ MÊS } & \multicolumn{2}{c}{ VIA REDE $\left(\mathbf{m}^{3} / \mathbf{m e ̂ s}\right)$} & \multicolumn{3}{c}{ VIA CAMINHÃO $\left(\mathbf{m}^{3} / \mathbf{m e ̂ s}\right)$} \\
\cline { 2 - 6 } & $\begin{array}{c}\text { Esgoto } \\
\text { Doméstico }\end{array}$ & E.N.D. & $\begin{array}{c}\text { Esgoto } \\
\text { Sanitário }\end{array}$ & E.N.D & Chorume \\
\hline JUN/07 & 1.437 .848 & 111.967 & 110 & 1.442 & 4.110 \\
JUL/07 & 1.734 .353 & 107.475 & 231 & 1.345 & 4.290 \\
AGO/07 & 1.482 .104 & 121.130 & 287 & 1.486 & 4.440 \\
SET/07 & 1.367 .130 & 113.111 & 210 & 1.243 & 2.790 \\
OUT/07 & 1.608 .126 & 114.672 & 211 & 1.498 & 3.270 \\
NOV/07 & 2.049 .570 & 123.003 & 230 & 1.450 & 2.970 \\
DEZ/07 & 2.159 .223 & 114.382 & 134 & 1.210 & 2.532 \\
JAN/08 & 2.427 .879 & 114.933 & 307 & 1.590 & 2.280 \\
FEV/08 & 2.077 .416 & 160.099 & 221 & 1.686 & 2.070 \\
MAR/08 & 1.815 .291 & 141.755 & 158 & 1.367 & 1.920 \\
ABR/08 & 1.986 .645 & 154.860 & 216 & 2.072 & 1.950 \\
MAI/08 & 1.775 .262 & 161.702 & 1.406 & 577 & 3.028 \\
\hline MÉDIA & $\mathbf{1 . 8 2 6 . 7 3 7}$ & $\mathbf{1 2 8 . 2 5 7}$ & $\mathbf{3 1 0}$ & $\mathbf{1 . 4 1 4}$ & $\mathbf{2 . 9 7 1}$ \\
\hline
\end{tabular}


A E.T.E. se divide em duas fases: líquida e sólida. A fase líquida é composta pelas etapas preliminar, primária e secundária. A fase preliminar tem por objetivo a remoção de materiais flutuantes de dimensões diversas para que não interfira em equipamentos e processos das etapas subseqüentes através de gradeamento grosseiro, fino e remoção de areia. Na fase primária, aproximadamente $20 \%$ da DBO é removida por decantação, gerando o lodo primário. A etapa secundária compreende o reator biológico, aonde são removidos praticamente toda a matéria orgânica biodegradável, e o tanque de clarificação ou decantador secundário, aonde o lodo ativado é separado do efluente final tratado, que é enviado ao corpo receptor. $\mathrm{Na}$ fase sólida é feito o tratamento do lodo gerado no decantador primário e o excesso do lodo do decantador secundário, além de uma grande parte dos efluentes não-domésticos que são recebidos via caminhão. $O$ tratamento se inicia nos digestores (sendo seis instalados e três em operação), aonde as bactérias anaeróbias transformam grande parte da matéria orgânica em gás metano. Em seguida, o lodo digerido é condicionado quimicamente, através da aplicação de cal e cloreto férrico, desaguado em filtros-prensa e enviado para aterro sanitário. A Figura 3 mostra um fluxograma do processo de tratamento da E.T.E.

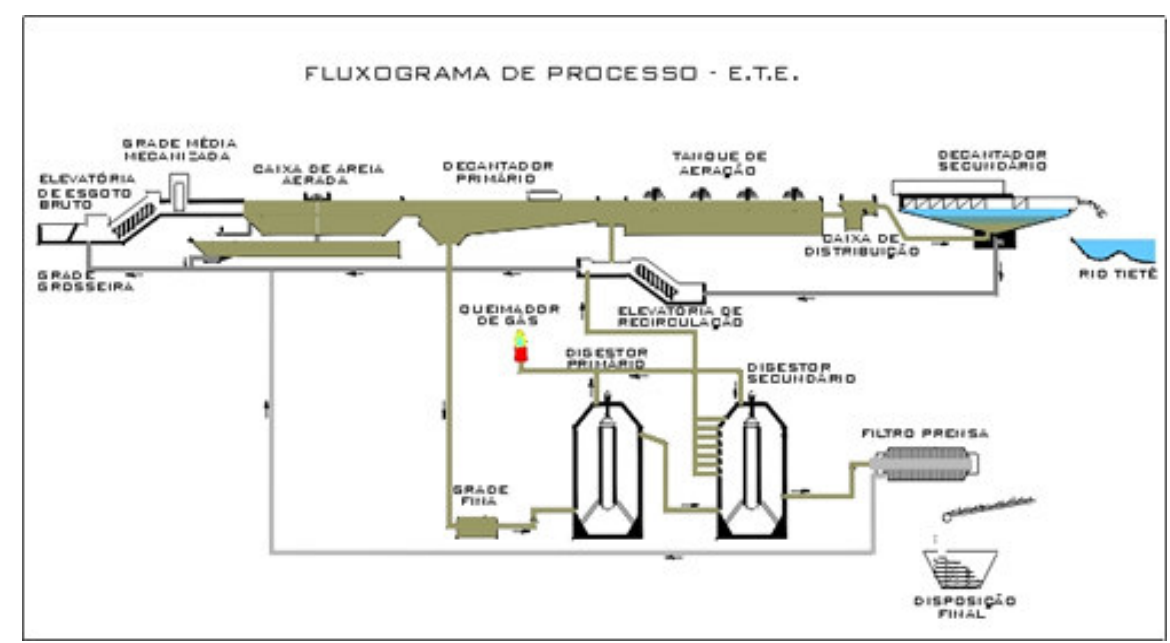

Figura 3 - Fluxograma de processo da E.T.E. objeto de estudo. Fonte: SABESP (2008)

\subsubsection{Caracterização do esgoto afluente e efluente da E.T.E.}

A Tabela 6 apresenta dados médios do esgoto afluente e efluente referente ao período entre junho de 2007 e maio de 2008. 
Tabela 6 - Caracterização do esgoto afluente e efluente da ETE objeto de estudo. Valores médios de junho de 2007 a maio de 2008.

\begin{tabular}{|c|c|c|c|}
\hline Parâmetro & Esgoto Afluente & Efluente Final & Eficiência \\
\hline $\mathrm{pH}$ & 7,3 & 7,1 & - \\
\hline SS (mLSS/L) & 7,2 & $<0,1$ & $99 \%$ \\
\hline ST (mgST/L) & 1119,2 & 802,3 & $28 \%$ \\
\hline SV (mgSV/L) & 368,7 & 118,9 & $68 \%$ \\
\hline SF (mgSF/L) & 750,5 & 683,4 & $9 \%$ \\
\hline SST (mgST/L) & 293,7 & 21,6 & $93 \%$ \\
\hline SSV (mgSSV/L) & 197,5 & 14,6 & $93 \%$ \\
\hline SSF (mgSSF/L) & 96,2 & 6,9 & $93 \%$ \\
\hline $\mathrm{DBO}\left(\mathrm{mgO}_{2} / \mathrm{L}\right)$ & 267,9 & 16,2 & $94 \%$ \\
\hline $\mathrm{DQO}\left(\mathrm{mgO}_{2} / \mathrm{L}\right)$ & 538,3 & 85,7 & $84 \%$ \\
\hline Fenol $\left(\mathrm{mgC}_{5} \mathrm{H}_{6} \mathrm{OH} / \mathrm{L}\right)$ & 0,4 & $<0,1605$ & $99 \%$ \\
\hline Fósforo Total (mgP/L) & 6,2 & 0,9 & $86 \%$ \\
\hline Nitrito (mgN-NO $\left.{ }_{2}^{-} / \mathrm{L}\right)$ & 0,5 & 2,4 & - \\
\hline Nitrato $\left(\mathrm{mgN}^{-\mathrm{NO}_{3}}{ }^{-} / \mathrm{L}\right)$ & 4,8 & 12,8 & - \\
\hline Nitrogênio Amoniacal (mgN-NH $/ / \mathrm{L})$ & 49,3 & 25,5 & $48 \%$ \\
\hline Nitrogênio Total Kjedahl (mgNTK/L) & 65 & 36 & $45 \%$ \\
\hline $\begin{array}{c}\text { Material Solúvel em N-Hexano } \\
(\mathrm{mgOG} / \mathrm{L})\end{array}$ & $<47$ & ND & $100 \%$ \\
\hline Sulfato $\left(\mathrm{mgSO}_{4}{ }^{2-} / \mathrm{L}\right)$ & 179,9 & 187,5 & - \\
\hline Sulfeto $\left(\mathrm{mgS}^{2-} / \mathrm{L}\right)$ & 2,0 & 0,0 & $99 \%$ \\
\hline Surfactante (mgLAS/L) & 5,2 & 0,5 & $91 \%$ \\
\hline Cor (UC) & 487 & 148 & $70 \%$ \\
\hline Condutividade $\left(\mu \mathrm{S} / \mathrm{cm}^{2}\right)$ & 1577,0 & 1558,3 & $1 \%$ \\
\hline Fluoreto $\left(\mathrm{mgF}^{-} / \mathrm{L}\right)$ & 0,5 & 0,7 & - \\
\hline Cádmio (mgCd/L) & $<0,015$ & $<0,015$ & - \\
\hline Cromo Hexavalente $\left(\mathrm{mgCr}^{6+} / \mathrm{L}\right)$ & $<0,003$ & $<0,003$ & - \\
\hline Cromo Total (mgCr/L) & 0,143 & $<0,065$ & $99 \%$ \\
\hline Cobre $(\mathrm{mgCu} / \mathrm{L})$ & 0,181 & $<0,045$ & $99 \%$ \\
\hline Ferro (mgFe/L) & 15,020 & 1,168454545 & $92 \%$ \\
\hline Ferro Solúvel $\left(\mathrm{mgFe}_{\mathrm{so}} / \mathrm{L}\right)$ & - & $<0,155$ & - \\
\hline Manganês (mgMn/L) & 0,882 & 0,498 & $44 \%$ \\
\hline Manganês Solúvel (mgMn sol $/ \mathrm{L})$ & - & 0,458 & - \\
\hline Molibdênio (mgMo/L) & 0,860 & 0,690 & $20 \%$ \\
\hline Níquel (mgNi/L) & 0,416 & 0,075 & $82 \%$ \\
\hline Chumbo (mgPb/L) & $<0,08$ & $<0,08$ & - \\
\hline Zinco (mgZn/L) & 3,786 & 0,807 & $79 \%$ \\
\hline
\end{tabular}

Fonte: SABESP (2008)

\subsection{Descrição da indústria química geradora de efluente}

A descrição da indústria química, a seguir, foi baseada em Sposito (2006), que trabalhou com o mesmo efluente em sua dissertação de mestrado.

A indústria química considerada no presente trabalho trata-se de uma multinacional de grande porte, instalada em uma área na qual existem outras doze unidades industriais independentes. 
Os efluentes são gerados, portanto, por treze células mais um incinerador de resíduos. Antes do lançamento dos efluentes na rede coletora da E.T.E., a indústria realiza um pré-tratamento composto por um tanque de correção de $\mathrm{pH}$, um decantador, um adensador de lodo e uma centrífuga. O lodo centrifugado é incinerado na própria indústria e o efluente do decantador é enviado para dois tanques de equalização, com volume de $2.400 \mathrm{~m}^{3}$ cada um. Na saída da indústria, após os tanques de equalização existe um poço de visita, onde está instalado um coletor automático, programado para coletar o efluente diariamente, em intervalos de uma hora. A partir de relatórios fornecidos pela própria indústria, foram identificadas as vazões de cada célula e os principais poluentes presentes, conforme Tabela 7.

Tabela 7 - Contaminantes presentes no efluente das células produtivas da indústria química

\begin{tabular}{|c|c|c|}
\hline Célula & Vazão de pico & Poluentes detectados \\
\hline 1 & $\mathrm{Q}=1,1 \mathrm{~m}^{3} / \mathrm{h}$ & Sulfato, cromo e ferro \\
\hline 2 & $\mathrm{Q}=54,0 \mathrm{~m}^{3} / \mathrm{h}$ & $\begin{array}{l}\text { Óleos e graxas, surfactantes, fenol, sulfato, sulfeto e } \\
\text { solventes (tolueno, xileno, tetracloroetileno) }\end{array}$ \\
\hline 3 & $\mathrm{Q}=30,0 \mathrm{~m}^{3} / \mathrm{h}$ & $\begin{array}{l}\text { Óleos e graxas, acrilonitrila, éter nitrila, formol, dimetilamina, } \\
\text { fluoreto, ferro, ácido sulfúrico, amônia e solventes (tolueno, } \\
\text { benzeno) }\end{array}$ \\
\hline 4 & $\mathrm{Q}=5,0 \mathrm{~m}^{3} / \mathrm{h}$ & Sulfato, surfactantes e solventes \\
\hline 5 & $\mathrm{Q}=37,0 \mathrm{~m}^{3} / \mathrm{h}$ & $\begin{array}{l}\text { Sulfetos, fenol, sulfato, fluoreto, arsênio e solventes } \\
\text { (dicloroetanos, xileno, benzeno, diclormetano, tricloroetano) }\end{array}$ \\
\hline 6 & $\mathrm{Q}=44,0 \mathrm{~m}^{3} / \mathrm{h}$ & $\begin{array}{l}\text { Óleos e graxas, surfactantes, sulfato, polímeros e solventes } \\
\text { (clorofórmio, benzeno) }\end{array}$ \\
\hline 7 & $\mathrm{Q}=70,0 \mathrm{~m}^{3} / \mathrm{h}$ & $\begin{array}{l}\text { Metais pesados, beta-naftol, 3,3-diclorobenzeno, fenol, } \\
\text { sulfato, manganês e solventes (tolueno, xileno) }\end{array}$ \\
\hline 8 & $\mathrm{Q}=4,2 \mathrm{~m}^{3} / \mathrm{h}$ & Glicóis, éteres, fenol, ferro e sulfato \\
\hline 9 & $\mathrm{Q}=2,5 \mathrm{~m}^{3} / \mathrm{h}$ & $\begin{array}{l}\text { Óleos e graxas, surfactantes, fenol, sulfato e solventes } \\
\text { (tolueno, xileno, tetracloroetileno, metil etil cetona) }\end{array}$ \\
\hline 10 & $Q=40,0 \mathrm{~m}^{3} / \mathrm{h}$ & $\begin{array}{l}\text { Metais pesados (cromo, cobre, zinco, ferro e manganês) e } \\
\text { sulfato }\end{array}$ \\
\hline 11 & $\mathrm{Q}=12,0 \mathrm{~m}^{3} / \mathrm{h}$ & Sulfato \\
\hline 12 & $\mathrm{Q}=0,85 \mathrm{~m}^{3} / \mathrm{h}$ & Provável presença de solventes \\
\hline 13 & $\mathrm{Q}=12,5 \mathrm{~m}^{3} / \mathrm{h}$ & Provável presença de solventes \\
\hline
\end{tabular}

Fonte: Sposito (2006). 
A Figura 4, a seguir, apresenta um croqui esquemático da empresa, demonstrando o fluxo do esgoto, desde as células produtivas, até o despejo na rede pública coletora, bem como as etapas de tratamento realizadas na empresa.

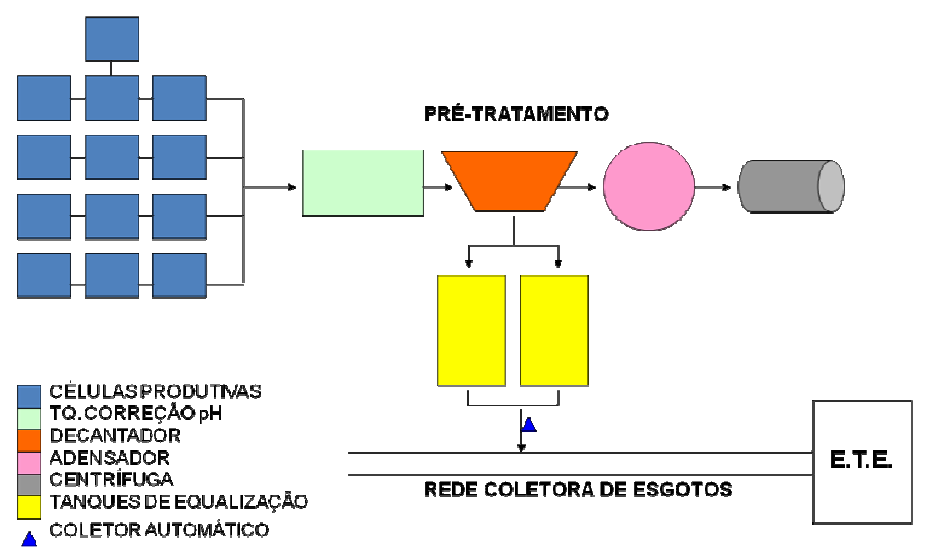

Figura 4 - Croqui esquemático demonstrando o fluxo do efluente gerado na indústria química.

\subsubsection{Caracterização físico-quimica do efluente industrial}

Uma vez por mês, ao longo de doze meses, foram compostas amostras do efluente industrial coletadas com coletor automático em intervalos de uma hora, durante 24 horas, as quais caracterizadas nos parâmetros: $\mathrm{pH}$, T으 série de sólidos, $\mathrm{DQO}, \mathrm{DBO}_{5,20}, \mathrm{NTK}, \mathrm{N}-\mathrm{NH}_{3}, \mathrm{P}, \mathrm{F}^{-}$, fenol, $\mathrm{SO}_{4}{ }^{2-}, \mathrm{S}_{2}{ }^{-}, \mathrm{Cl}^{-}, \mathrm{OG}$, surfactantes, $\mathrm{Cr}_{\text {total }}, \mathrm{Cd}$, $\mathrm{Cu}, \mathrm{Fe}, \mathrm{Mn}_{\text {total }}$ e $\mathrm{Mn}_{\text {solúvel, }} \mathrm{Ni}, \mathrm{Pb}$ e $\mathrm{Zn}$. A preservação das amostras, bem como os procedimentos analíticos para determinação destes parâmetros foram realizados segundo o APHA; AWWA; WEF (1998).

\subsubsection{Determinação dos poluentes orgânicos no efluente da indústria química}

As amostras de efluente industrial coletadas no ponto de lançamento na rede coletora apresentaram-se inadequadas para os ensaios de cromatografia, uma vez que possuíam diversos interferentes que poderiam levar a resultados incorretos. Dessa forma, optou-se por quantificar os poluentes orgânicos oriundos da indústria química que estivessem presentes no efluente final da E.T.E, sendo possível determinar quais são refratários ao tratamento e que, portanto, podem estar relacionados à toxicidade do efluente final. Para confirmar se a origem dos poluentes era realmente a indústria química, foram montados, em escala laboratorial, dois 
reatores por batelada que simulariam o tanque de aeração da estação de tratamento. Os reatores foram alimentados conforme abaixo:

- Reator 1 = esgoto doméstico + lodo ativado + efluente industrial;

- Reator 2 = esgoto doméstico + lodo ativado

Para reproduzir uma situação operacional a mais próxima possível da condição real de tratamento, os reatores foram alimentados de esgoto afluente coletado em um ponto aonde não há interferência do efluente industrial e biomassa (lodo ativado) da própria estação de tratamento. No reator 1, o efluente industrial foi adicionado na proporção de $7 \%(\mathrm{v} / \mathrm{v})$, equivalente ao volume máximo recebido em escala real na estação de tratamento (SABESP, 2008). Os volumes de esgoto afluente, biomassa efluente industrial foram calculados conforme a seguir (SPOSITO, 2006):

$$
\mathrm{V}_{\mathrm{B}}=\frac{\mathrm{SSV}_{\mathrm{TA}} \times \mathrm{V}_{\mathrm{R}}}{\mathrm{SSV}_{\mathrm{LB}}}
$$

Onde:

$V_{B}=$ Volume da biomassa no reator em batelada $(L)$

$\mathrm{SSV}_{\mathrm{TA}}=$ Sólidos em suspensão voláteis no tanque de aeração $(\mathrm{mg} / \mathrm{L})$

$\mathrm{V}_{\mathrm{R}}=$ Volume útil do reator em batelada $(\mathrm{L})$

$\mathrm{SSV}_{\mathrm{LB}}=$ Sólidos em suspensão voláteis no lodo ativado $(\mathrm{mg} / \mathrm{L})$

O volume de esgoto afluente (EA) sem interferência do efluente industrial foi calculado através da seguinte equação:

$$
\mathrm{V}_{\mathrm{EA}}=\mathrm{V}_{\mathrm{R}}-\mathrm{V}_{\mathrm{B}}
$$

Onde:

$V_{E A}=$ Volume de esgoto afluente sem interferência do efluente industrial (L)

O volume de efluente industrial adicionado nos reatores foi calculado através da seguinte equação: 


$$
\mathrm{V}_{\mathrm{EI}}=\frac{\mathrm{Q}_{\text {EIMAX }} \times \mathrm{V}_{\mathrm{EA}}}{\mathrm{Q}_{\text {EAMIN }}}
$$

Onde:

$\mathrm{V}_{\mathrm{EI}}=$ Volume do efluente industrial $(\mathrm{L})$

$\mathrm{Q}_{\text {EIMAX }}=$ Vazão máxima do efluente industrial (L/S)

$\mathrm{Q}_{\text {EAMIN }}=$ Vazão mínima do esgoto afluente $(\mathrm{L} / \mathrm{s})$

$\mathrm{V}_{\mathrm{EA}}=$ Volume do esgoto afluente $(\mathrm{L})$

Para as vazões de esgoto afluente à E.T.E. e de efluente industrial, foram considerados dados de vazão dos últimos doze meses, conforme abaixo:

$$
\begin{aligned}
& Q_{\text {EAMIN }}=700 \mathrm{~L} / \mathrm{s} \\
& Q_{\text {EIMAX }}=50 \mathrm{~L} / \mathrm{s}
\end{aligned}
$$

A Figura 5 ilustra uma representação esquemática da alimentação dos dois biorreatores.

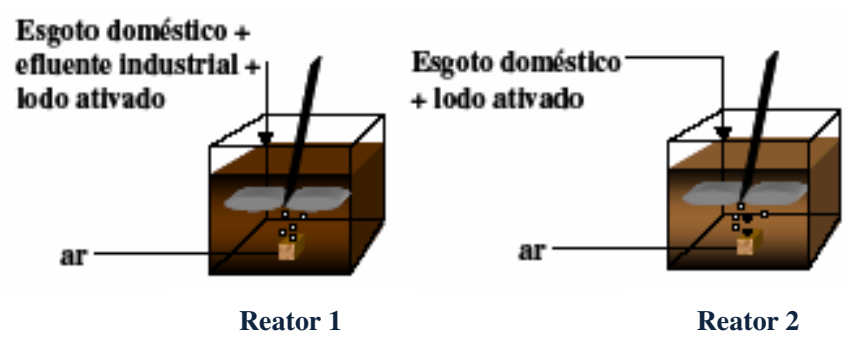

Figura 5 - Esquema de montagem dos reatores para simulação do recebimento de efluente industrial para amostragem do efluente final.

A amostra foi submetida à agitação a 56 rpm e oxigenação na faixa entre 1,0 e 2,0 mgOD/L, por um período de 10 horas. Ao final desse período, os reatores foram deixados em repouso por 2 horas e foram coletadas amostras em triplicata do sobrenadante em frascos que impedem a volatilização do poluente até o momento do ensaio.

Há que se considerar que a detecção dos poluentes foi feita com amostras pontuais porque, de acordo com APHA; AWWA; WEF (1998), para ensaios de 
cromatografia de poluentes orgânicos voláteis, não é recomendada a composição da amostra. Os parâmetros analisados foram: benzeno, o-, $m$ - $p$-xileno, tolueno, fenol, 1,1-dicloroeteno, 1,2-dicloroetano, pentaclorofenol, tetracloreto de carbono, clorofórmio e tricloroeteno. O fenol foi o único poluente orgânico quantificado por espectrofotometria.

\subsubsection{Ensaios de cromatografia}

Os poluentes orgânicos foram extraídos e quantificados em cromatógrafo gasoso equipado com detector de massa GC-MS Saturn 2.100D, de acordo com os procedimentos descritos por APHA; AWWA; WEF (1998).

\subsubsection{Detecção de fenol por espectrofotometria}

A detecção espectrofotométrica de fenol foi realizada de acordo com os procedimentos descritos por APHA; AWWA; WEF (1998).

\subsection{Ensaios de toxicidade aguda para organismos Daphnia similis e Vibrio fischeri}

No presente trabalho optou-se por realizar testes de toxicidade aguda para o microcrustáceo Daphnia similis Claus 1876 (Cladocera, Crustacea) e a bactéria luminescente Vibrio fischeri. Os testes foram adotados em duas fases diferentes do trabalho, com as seguintes finalidades:

1. Avaliação das condições ecotoxicológicas do efluente final da estação de tratamento em escala real.

Para a realização desse teste, foram coletadas três amostras do efluente final da estação de tratamento em três datas distintas, nas quais a estação de tratamento estava sob inibição no seu processo biológico e apresentando valores elevados de turbidez no efluente final, eficiência de remoção de DQO mais baixa comparando-se com uma situação normal de processo e perturbação na microfauna de protozoários e micrometazoários (dados não exibidos). Foram feitas, ainda, três outras coletas, também em datas distintas, mas com boas condições de operação na estação de 
tratamento, cujo valor de turbidez do efluente final encontrava-se baixo, alta eficiência de remoção de DQO e boas condições microbiológicas.

2. Avaliação da bioaumentação na remoção de toxicidade do efluente final.

Os testes de biaumentação com linhagens isoladas puras e consórcios microbianos, realizados em escala laboratorial, foram avaliados quanto à remoção de toxicidade no efluente final da estação de tratamento. Foram medidas a variação da toxicidade do efluente industrial e a toxicidade do efluente final da estação de tratamento após recebimento do efluente industrial pré tratado, bem como o efluente final da estação tratamento em uma situação de recebimento do efluente industrial com adição de microrganismos direto no tanque de aeração. Todos os ensaios foram comparados com um biorreator controle, no qual não foram inseridos microrganismos.

Os ensaios de toxicidade aguda para os microrganismos Daphnia similis e Vibrio fischeri foram realizados conforme procedimentos descritos pelas Normas ABNT-NBR 12.713 e 15.411-3, respectivamente. Os resultados foram expressos em Unidades Tóxicas (UT).

\subsection{Obtenção das linhagens microbianas}

\subsubsection{Amostras}

Foram coletadas amostras da biomassa da estação de tratamento para isolamento das linhagens bacterianas. Para garantir condições que permitissem a presença do maior número e diversidade de microrganismos possíveis, foram verificadas nas datas das coletas as condições operacionais da estação quanto à eficiência de remoção de matéria orgânica, medida em Demanda Química de Oxigênio, turbidez do efluente final e análise quantitativa e qualitativa da fauna de protozoário e micrometazoários do reator biológico ou tanque de aeração da estação de tratamento de esgotos, além da caracterização das amostras em relação a pH, temperatura e concentração de sólidos em suspensão voláteis - SSV (dados não apresentados). As amostras que apresentaram valores condizentes com situações de inibição no processo foram descartadas. 


\subsubsection{Isolamento dos microrganismos}

As amostras da biomassa da estação de tratamento selecionadas para os isolamentos foram diluídas até $10^{6}$ vezes em solução salina e inoculas em placas de Petri estéreis contendo meio mineral $\left(\mathrm{Na}_{2} \mathrm{HPO}_{4} 3,5 \mathrm{~g} / \mathrm{L} ; \mathrm{KH}_{2} \mathrm{PO}_{4} 1,5 \mathrm{~g} / \mathrm{L} ;\left(\mathrm{NH}_{4}\right)_{2} \mathrm{SO}_{4}\right.$ $1,0 \mathrm{~g} / \mathrm{L} ; \mathrm{MgSO}_{4} .7 \mathrm{H}_{2} \mathrm{O} 1 \mathrm{~mL} / \mathrm{L} ; \mathrm{CaCl}_{2} .2 \mathrm{H}_{2} \mathrm{O} 1 \mathrm{~mL} / \mathrm{L}$; citrato ferroso amoniacal $1 \mathrm{~mL} / \mathrm{L}$; solução de elementos traços $1 \mathrm{~mL} / \mathrm{L}$ ), (RAMSAY et al., 1990), conforme figura 6, a seguir. Como fonte de carbono, foram utilizados os poluentes detectados por cromatografia gasosa que, de acordo com os resultados apresentados na Tabela 10, poderiam estar relacionados a eventos de inibição e, consequentemente, toxicidade no efluente final da estação de tratamento de esgotos: 1,1-dicloroeteno, 1,2dicloroetano, benzeno, clorofórmio, pentaclorofenol, tolueno, tricloroeteno e $p$-xileno. Esses compostos tratam-se de compostos orgânicos voláteis, dessa forma foram colocados em frascos de $2 \mathrm{~mL}$ perfurados para que o composto volatilizasse e penetrasse nas placas. As placas e os frascos foram depositados no interior de caixas seladas.

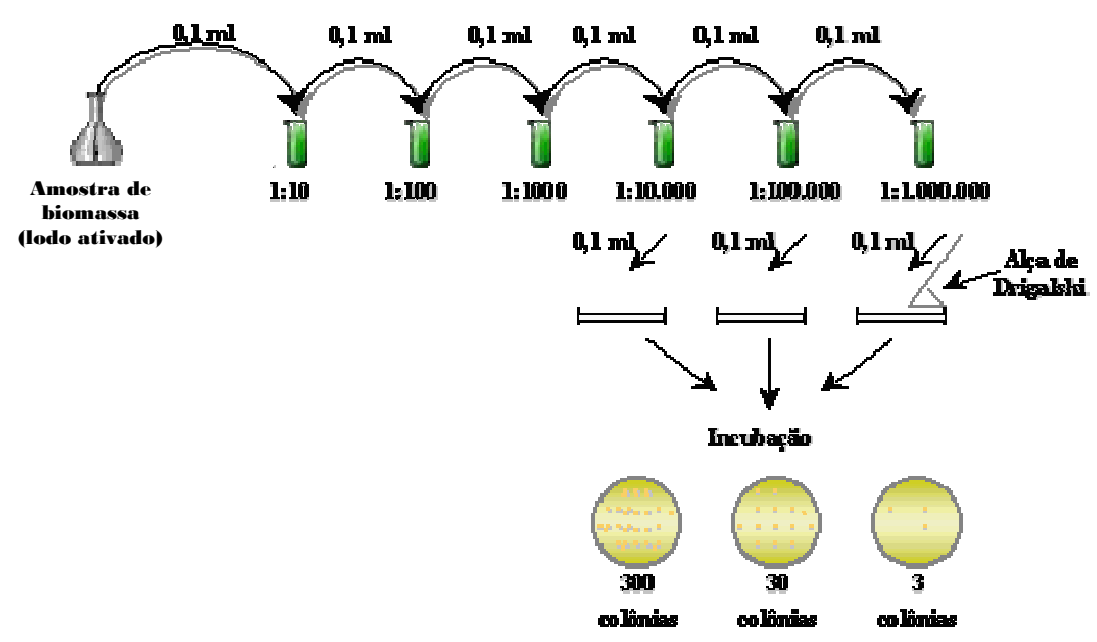

Figura 6 - Esquema de diluição das amostras de biomassa da estação de tratamento e inoculação em placas de Petri.

O crescimento ocorreu em 7 dias a $30 \stackrel{\circ}{ } \mathrm{C}$. Foram selecionadas as colônias que apresentaram crescimento mais significativo, que foram estriadas em novas placas contendo meio mineral sólido, para isolamento direto sob as mesmas condições de cultivo. As linhagens foram identificadas por prefixos de acordo com a fonte de carbono DCE (1,2-dicloroetano), BEN (benzeno), CLF (clorofórmio), PCF (pentaclorofenol), TOL (tolueno), TCE (tricloroeteno) e XIL (xileno), seguidos de uma 
seqüência numérica. Após o período de cultivo, as linhagens foram sucessivamente repicadas para novas placas, até que se confirmasse o seu isolamento.

\subsubsection{Avaliação do crescimento microbiano em diferentes fontes de carbono}

\subsubsection{Pré-inóculo}

Dos microrganismos isolados, foram selecionados os que apresentaram crescimento mais significativo em placa de Petri. Esses microrganismos foram inoculados em tubos de $15 \mathrm{~mL}$ contendo $5 \mathrm{~mL}$ de caldo nutriente $(3 \mathrm{~g} / \mathrm{L}$ de extrato de levedura e $5 \mathrm{~g} / \mathrm{L}$ de peptona bacteriológica). Os tubos foram colocados em agitador rotativo (120 rpm; $30{ }^{\circ} \mathrm{C}$ ) por 24 horas. Após o período de crescimento do préinóculo, os tubos foram centrifugados a 5.000 rpm por 20 minutos, para separar as células do meio de cultura. Em seguida foram ressuspensas em $1 \mathrm{~mL}$ de solução de $\mathrm{NaCl}$ 0,85\% (m/v). O conteúdo foi transferido para frascos erlenmeyer devidamente estéreis contendo $150 \mathrm{~mL}$ de meio mineral.

\subsubsection{Leitura espectrofotométrica da $\mathrm{DO}_{610}$}

Nos frascos erlenmeyer contendo meio mineral foram adicionados $1 \mathrm{~mL}$ de inoculo e então colocados em agitador rotativo $\left(120 \mathrm{rpm} / 30^{\circ} \mathrm{C}\right)$, por sete dias $(168$ horas) de cultivo. Em intervalos de 24 horas, foram retiradas amostras de $5 \mathrm{~mL}$ para centrifugação a 10.000 rpm por 10 minutos. Os pellets acumulados no fundo dos frascos foram ressuspensos em solução salina 0,85\% e submetidos à leitura da absorbância em espectrofotômetro, no comprimento de onda de 610 nanômetros. Foram adicionados $5 \mathrm{~mL}$ de fonte de carbono em tubos estéreis, com um pequeno orifício na tampa plástica para que o composto orgânico volatilizasse e penetrasse no meio de cultura. Os tubos foram posicionados no interior dos frascos erlenmeyer, conforme demonstrado na Figura 7.

Definiu-se selecionar três linhagens por fonte de carbono nos experimentos de cinética de crescimento, baseado no fato de apresentar melhor crescimento, medido em absorbância. Ao final do experimento, as linhagens foram reestriadas em placas de Petri contendo Agar nutriente para verificação de contaminação durante o teste. 


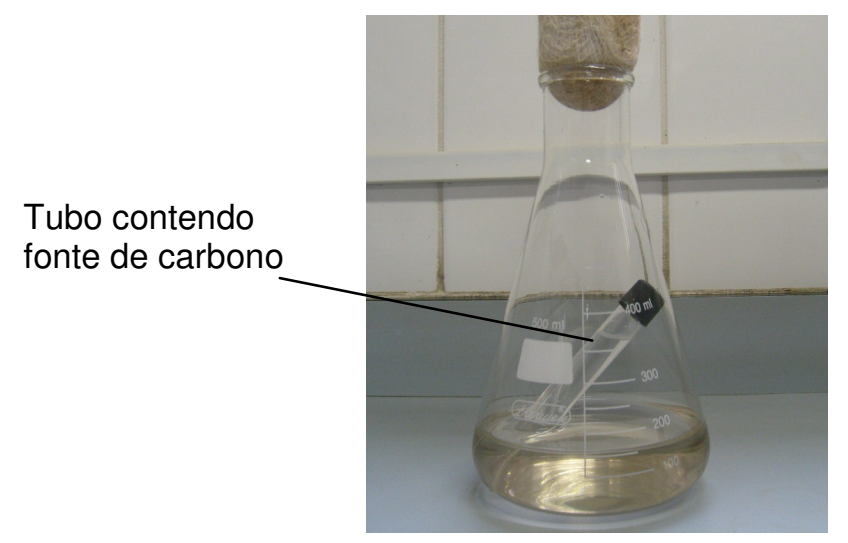

Figura 7 - Frasco erlenmeyer com $150 \mathrm{~mL}$ de meio mineral com tubo contendo fonte de carbono, utilizado nas leituras da $\mathrm{DO}_{610}$.

\subsection{Testes de Bioaumentaçao}

Os testes de bioaumentação foram realizados em um equipamento jar test da marca Polilab ${ }^{\circledR}$ modelo Turbo-Floc $2 P$, composto de seis cubas com capacidade de 2,5 litros de amostra cada uma, além de entrada para ar em cada cuba. A agitação foi mantida em 56 rpm durante todo o período de teste e a oxigenação na faixa de 1,0 a 2,0 mgOD/L, controlada por um oxímetro da marca Analyser ${ }^{\circledR}$. Inicialmente foi preparado um pré-inóculo em $15 \mathrm{~mL}$ de caldo nutriente que foi centrifugado a 10.000 rpm por 10 minutos. O sobrenadante foi desprezado e o pellet concentrado no fundo foi ressuspenso em $15 \mathrm{~mL}$ de solução de $\mathrm{NaCl} 0,85 \%$ (m/v), o qual foi imediatamente adicionado nas amostras a serem bioaumentadas. Nos testes em que foram adotados consórcios microbianos, foram colocadas no tubo $1 \mathrm{~mL}$ de amostra de cada linhagem que também foi centrifugada e ressuspensa, antes da adição no jar test.

Os testes foram divididos em dois grupos: A e B. O teste A consistiu na adição das linhagens microbianas diretamente no efluente industrial, o qual foi tratado durante 36 horas nas condições de homogeneização e oxigenação descritas anteriormente. Esse efluente industrial foi dosado em biorreatores simulando 0 tanque de aeração da estação de tratamento de esgotos após seu pré tratamento. $O$ teste $B$ tratou-se da adição dos microrganismos no biorreator que simula o tanque de aeração da E.T.E. após o recebimento do efluente industrial sem pré tratamento. Este teste foi realizado no tempo de detenção do tanque de aeração da ETE, que é de 10 horas. Em ambos os testes foram montados reatores controle em triplicata. 
Cada teste foi realizado em duas condições: 1. com as linhagens microbianas puras; 2. com consórcios degradadores de cada composto tóxico, compostos pelas três linhagens de microrganismos selecionadas. Os testes foram identificados conforme a seguir:

- Teste A1 - Bioaumentação do efluente industrial com linhagens puras;

- Teste A2 - Bioaumentação do efluente industrial com consórcios microbianos;

- Teste B1 - Bioaumentação do tanque de aeração com linhagens puras;

- Teste B2 - Bioaumentação do tanque de aeração com consórcios microbianos.

Um esquema dos testes A e B é apresentado na Figura 8, a seguir:

TESTE A:

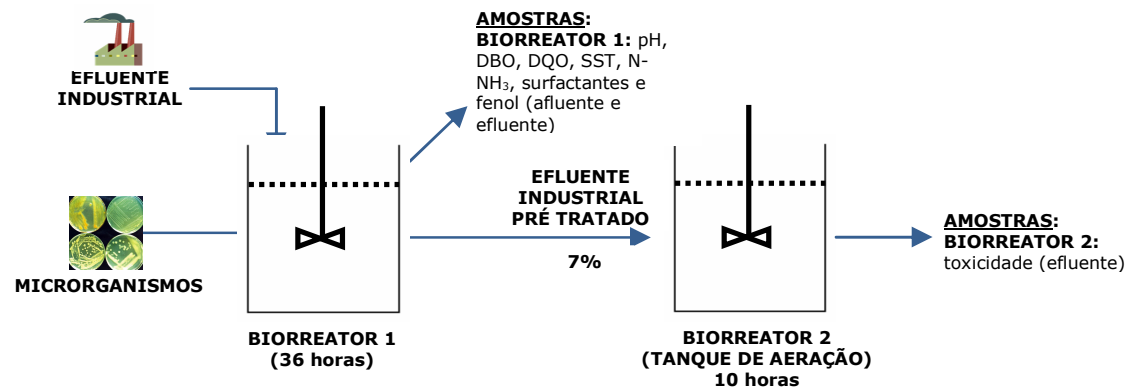

TESTE B:

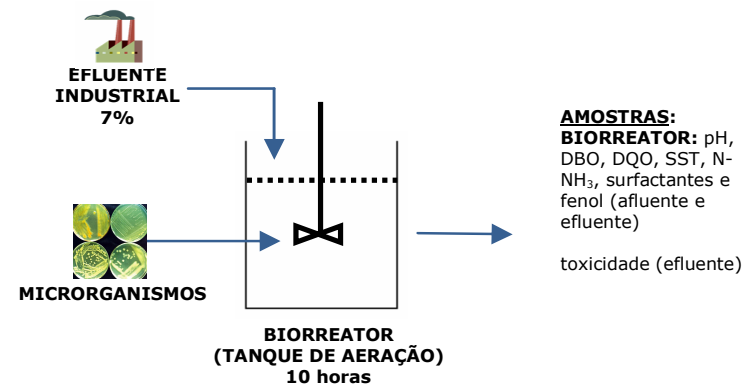

Figura 8 - Esquema dos testes de bioaumentação realizados no efluente industrial (teste A) e diretamente no biorreator que simulou o tanque de aeração (teste B).

\subsubsection{Pré-tratamento das amostras do efluente da indústria química}

Foram realizados dois testes de adição de inóculo diretamente no efluente da indústria química. No primeiro teste foram utilizadas as linhagens separadamente para cada biorreator. No segundo, foram compostos consórcios microbianos especializados na degradação de cada composto orgânico, formados pelas três linhagens selecionadas nos testes de cinética de crescimento. Cada teste teve uma 
duração de 36 horas, nas condições de agitação e oxigenação descritas anteriormente. Paralelamente, foram utilizadas amostras sem adição de inóculos para comparação da toxicidade do efluente final em ambas as condições. Ao final do período de pré-tratamento, as amostras foram adicionadas em um reator biológico que simula o tanque de aeração da estação de tratamento, na proporção média em que tal efluente é recebido - 7\% (v/v). O tratamento consistiu na aeração e agitação nas mesmas condições descritas anteriormente, porém em um intervalo de 10 horas, correspondente ao tempo de detenção hidráulico do tanque de aeração da estação de tratamento de efluentes estudada.

A biomassa do sistema foi composta por 50\% de amostra de esgoto doméstico proveniente de ponto sem interferência do efluente industrial acrescido de $50 \%$ da biomassa do sistema de tratamento - lodo ativado - da própria estação de tratamento de esgotos. Dessa maneira criou-se uma simulação mais próxima das condições reais de tratamento.

Ao final do intervalo de 10 horas, a aeração e a agitação foram desligadas e seguiu-se um período de repouso, onde se formou um sobrenadante por decantação. Amostras do sobrenadante dos testes realizados tanto com linhagens puras quanto com os consórcios microbianos, bem como do biorretor controle, foram retiradas para os ensaios de toxicidade aguda com $D$. similis e $V$. fischeri. Também foram coletas amostras afluente e efluente dos biorreatores utilizados no pré tratamento do efluente industrial e dos biorreatores que simularam o tanque de aeração da E.T.E. para analise dos parâmetros operacionais $(\mathrm{pH}$, Demanda Química de Oxigênio, Sólidos em Suspensão Totais, Nitrogênio Amoniacal, Surfactantes e Fenol) e para detecção de poluentes orgânicos dos biorreatores alimentados por efluente industrial pré-tratados por consórcios. Todos os parâmetros fisico-químicos analisados seguiram a metodologia proposta por APHA; AWWA; WEF (1998).

\subsubsection{Biaumentação direta no reator biológico}

Além do teste de pré-tratamento do efluente industrial e posterior simulação de recebimento na estação de tratamento, também foram feitos outros dois testes simulando o recebimento do efluente industrial diretamente no reator biológico, sem que houvesse pré-tratamento da amostra de efluente industrial. As linhagens microbianas foram adicionadas diretamente no reator biológico, sendo que no 
primeiro teste foram utilizadas as linhagens puras e no segundo, consórcios microbianos. O procedimento para obtenção dos inóculos, as condições de oxigenação e agitação, bem como as coletas para ensaios ecotoxicológicos e detecção de poluentes orgânicos foram similares ao teste descrito anteriormente.

\subsection{Caracterização dos isolados}

\subsubsection{Caracterização fenotípica}

A caracterização fenotípica foi realizada para classificar os organismos isolados e utilizados nos testes de bioaumentação de acordo com características morfofisiológicas em comum, para que fosse identificado um representante de cada grupo, através do seqüenciamento do rRNA 16S. Os parâmetros analisados foram: coloração da colônia; teste de oxidase, teste de catalase e coloração de Gram.

\subsubsection{Caracterização molecular}

\subsubsection{Extração do DNA genômico dos isolados}

Inicialmente, as linhagens foram cultivadas por 24 horas em frascos erlenmeyer contendo $25 \mathrm{~mL}$ de meio LB sob agitação a 150 RPM a $30 \stackrel{\circ}{\circ}$. O DNA genômico das linhagens foi extraído com o auxílio do kit para extração de DNA Invitrogen ${ }^{\circledR}$, de acordo com as orientações do fabricante. Para visualização e análise do DNA foi utilizada a técnica de eletroforese em gel de agarose $3 \%(\mathrm{~m} / \mathrm{v})$ em solução TBE (tris-hidroximetilaminometano) 5,6 g/L, ácido bórico 27,5 g/L, EDTA de cálcio $0,5 \mathrm{M} 20 \mathrm{~mL} / \mathrm{L}$ ), realizadas a $80 \mathrm{~V}, 110 \mathrm{~mA}, 90 \mathrm{~W}$, por aproximadamente 2 horas. Os fragmentos de DNA foram observados após coloração de gel com solução de brometo de etídio $(0,05 \mathrm{mg} / 100 \mathrm{~mL}$ de TBE) durante 10 minutos. O gel após a corrida foi visualizado sob luz de UV e fotodocumentador KODAK ${ }^{\circledR}$ Gel Logic 100 Imaging System. 


\subsubsection{Amplificação da região $16 \mathrm{~S}$ rDNA}

O gene 16S rDNA foi amplificado pela técnica de Reação em Cadeia da Polimerase - PCR, em inglês, utilizando-se os iniciadores 27f (5' -AGA GTT TGA TCM TGG CTC AG-3') (LANE, 1991) e 1401r (5' - CGG TGT GTA CAA GAC CC -3') (HEUER et al., 1997). Nas reações de PCR foi empregado o kit Go Taq ${ }^{\circledR}$ Green Master Mix de acordo com indicação do fabricante. A reação de amplificação foi realizada no termociclador Mastercycler Gradient Eppendorf ${ }^{\circledR}$. As condições de amplificação empregadas foram: uma desnaturação inical por 2 minutos a $94{ }^{\circ} \mathrm{C}$, seguida de 30 ciclos de 1 minuto a $94{ }^{\circ} \mathrm{C}, 1$ minuto a $56{ }^{\circ} \mathrm{C}, 3$ minutos a $72{ }^{\circ} \mathrm{C}$ e uma extensão final de 10 minutos a $72{ }^{\circ} \mathrm{C}$. Os produtos de PCR foram visualizados pela técnica de eletroforese em gel de agarose $3 \%(\mathrm{~m} / \mathrm{v})$, descrita anteriormente, na qual foram utilizados $3 \mu \mathrm{L}$ de amostra.

\subsubsection{Análise de restrição de DNA ribossomal - ARDRA}

O método de análise de restrição de DNA ribossomal - ARDRA - foi utilizado para diferenciar os isolados em nível molecular, conforme protocolo proposto por Massol-Deya et al. (1995). Os produtos de amplificação das reações de PCR foram digeridos com as enzimas de restrição Hhal (GCG'C) e Haelll (GG'CC) de acordo com a indicação do fabricante (Invitrogen ${ }^{\circledR}$ ). Uma alíquota de $2 \mu \mathrm{L}$ de produto de PCR contendo $70 \mathrm{ng}$ foram misturados a $2 \mu \mathrm{L}$ de tampão 4 (10x), $1 \mu \mathrm{L}$ da enzima de restrição $(10 \mathrm{U} / \mu \mathrm{L})$, completando com água livre de nuclease para um volume final de $20 \mu \mathrm{L}$, incubados a $30{ }^{\circ} \mathrm{C}$ por $16 \mathrm{~h}$. Posteriormente, as enzimas foram inativadas a $70 \stackrel{\circ}{ } \mathrm{C}$ por $15 \mathrm{~min}$. Volumes de $7 \mu \mathrm{L}$ de cada amostra, de produto da digestão com as enzimas de restrição, foram visualizados pela técnica de eletroforese em gel de agarose $3 \%(\mathrm{~m} / \mathrm{v})$, descrita anteriormente, e analisados conforme os perfis de restrição. De acordo com o padrão de bandas apresentado para cada enzima de restrição, as linhagens foram classificadas em diferentes grupos. 


\section{RESULTADOS E DISCUSSÃO}

\subsection{Caracterização do efluente industrial}

A caracterização do efluente industrial demonstrou que se trata de esgoto com grande variação qualitativa em sua característica, conforme observado na Tabela 8, a seguir. Este resultado já era esperado uma vez que, devido ao fato da indústria química ser composta por diferentes células produtivas, há grande variação nos insumos utilizados e nas vazões das mesmas, o que conseqüentemente se traduz na geração de efluentes com diferenças significativas. Resultados semelhantes foram observados por Sposito (2006) quando caracterizou o mesmo efluente em um período anterior. De acordo com as conclusões desse trabalho, há indícios que o efluente pode estar relacionado à toxicidade no efluente final da estação de tratamento provavelmente ocasionado por compostos orgânicos, não quantificados pela autora na ocasião.

A variação dos resultados dos parâmetros analisados durante a caracterização do efluente industrial é um fator de bastante relevância para o presente trabalho, uma vez que podem ocorrer ocasiões em que a presença do efluente pode não significar inibição no processo e/ou toxicidade no efluente final. Sposito (2006) realizou diversos testes de respirometria que comprovaram a agressividade do efluente industrial sobre a biomassa da estação de tratamento, entretanto, no presente trabalho, foram feitos testes aleatórios de respirometria e o mesmo efeito não foi observado (dados não exibidos). Ao contrário do esperado, a presença do efluente industrial na ocasião do teste, exerceu pouco impacto sobre a respiração da biomassa, e ainda houve uma sensível elevação nas taxas de remoção de matéria orgânica, medida em DQO, e nitrogênio amoniacal, parâmetros monitorados na ocasião. 
Tabela 8 - Valores mínimos, médios e máximos de concentrações de parâmetros físico-químicos obtidos na caracterização do efluente industrial durante o período de junho de 2007 a junho de 2008 e variação de ocorrência dos parâmetros.

\begin{tabular}{|c|c|c|c|c|}
\hline PARÂMETRO & MINIMO & MÉDIA & MÁXIMO & VARIAÇÃO (\%) \\
\hline $\mathrm{pH}$ & 6,9 & 8,1 & 9,0 & 23 \\
\hline DQO mg O2/L & $1.542,3$ & $2.322,8$ & $4.679,8$ & 67 \\
\hline \multicolumn{5}{|c|}{ Sólidos } \\
\hline ST $\mathrm{mg} / \mathrm{L}$ & $3.363,0$ & $5.774,4$ & $10.553,0$ & 68 \\
\hline SV mg/L & 431,5 & $1.030,9$ & $1.030,9$ & 58 \\
\hline $\mathrm{SF} \mathbf{m g} / \mathrm{L}$ & $2.377,0$ & $4.743,5$ & $7.383,0$ & 68 \\
\hline SST mg/L & 79,0 & 342,7 & $1.105,0$ & 93 \\
\hline SSV mg/L & 41,0 & 204,8 & 625,0 & 93 \\
\hline SSF mg/L & 38,0 & 137,9 & 480,0 & 92 \\
\hline SS mL/L & 0,7 & 52,5 & 140,0 & 99,5 \\
\hline \multicolumn{5}{|c|}{ Metais } \\
\hline Fe mg Fe/L & 0,572 & 1,581 & 2,803 & 80 \\
\hline $\mathrm{Pb} \mathrm{mg} \mathrm{Pb} / \mathrm{L}$ & $<0,08$ & 0,110 & 0,239 & 83 \\
\hline $\mathrm{Cd} \mathrm{mg} \mathrm{Cd/L}$ & $<0,015$ & 0,020 & 0,026 & 71 \\
\hline $\mathrm{Cr} \mathrm{mg} \mathrm{Cr} / \mathrm{L}$ & $<0,065$ & 0,042 & 0,106 & 69 \\
\hline Mn mg Mn/L & 0,120 & 1,892 & 8,075 & 99 \\
\hline Cu mg Cu/L & $<0,045$ & 0,171 & 0,412 & 95 \\
\hline $\mathrm{Ni} \mathrm{mg} \mathrm{Ni/L}$ & $<0,045$ & 0,125 & 0,246 & 91 \\
\hline Zn mg Zn/L & 0,380 & 0,826 & 1,404 & 73 \\
\hline $\mathrm{Fe}_{\text {sol }} \mathrm{mg} \mathrm{Fe} / \mathrm{L}$ & 0,318 & 0,362 & 0,406 & 22 \\
\hline $\mathrm{Mn}_{\text {sol }} \mathrm{mg} \mathrm{Mn/L}$ & 0,118 & 1,448 & 6,070 & 98 \\
\hline $\mathrm{Cu}_{\mathrm{sol}} \mathrm{mg} \mathrm{Cu} / \mathrm{L}$ & 0,144 & 0,144 & 0,144 & * \\
\hline \multicolumn{5}{|c|}{ Nitrogênio e Fósforo } \\
\hline N_NH ${ }_{3} \mathbf{m g N}-\mathrm{NH}_{3} / \mathrm{L}$ & 127,7 & 241,9 & 408,2 & 69 \\
\hline NTK mg N/L & 149,8 & 256,2 & 463,2 & 68 \\
\hline FOSFORO mg P/L & 0,6 & $\begin{array}{r}1,9 \\
\text { utros }\end{array}$ & 4,8 & 87 \\
\hline F mg F/L & 0,9 & 0,9 & 0,9 & * \\
\hline ATA mg LAS/L & 0,6 & 2,5 & 5,2 & 88 \\
\hline OG mg/L & $<7$ & 67,4 & 200,0 & 98 \\
\hline FENOL $\mathrm{mgC}_{6} \mathrm{H}_{5} \mathrm{OH} / \mathrm{L}$ & 0,8 & 7,8 & 50,1 & 98 \\
\hline $\mathrm{Cl} \mathrm{mgCl} / \mathrm{L}$ & 944,6 & $1.643,7$ & $3.778,0$ & 75 \\
\hline
\end{tabular}

* Somente um ensaio realizado. Os demais parâmetros foram analisados uma vez por mês, ao longo de doze meses.

A Tabela 9, a seguir, apresenta os resultados dos ensaios para detecção dos compostos orgânicos nos biorreatores alimentados com o efluente industrial, comparados com os biorreatores controle. 
Tabela 9 - Poluentes orgânicos detectados em amostragens de efluente final de biorreatores alimentados com (reator 1) e sem (reator 2) efluente proveniente da indústria química.

\begin{tabular}{|c|c|c|c|c|}
\hline \multirow[b]{2}{*}{ Poluente (g/L) } & \multicolumn{2}{|c|}{ Amostragem A } & \multicolumn{2}{|c|}{ Amostragem B } \\
\hline & 1 & 2 & 1 & 2 \\
\hline 1,1-dicloroeteno & $<1 \mu g / L$ & ND & $<1 \mu g / L$ & ND \\
\hline 1,2-dicloroetano & $950 \mu \mathrm{g} / \mathrm{L}$ & $<1 \mu \mathrm{g} / \mathrm{L}$ & $847 \mu \mathrm{g} / \mathrm{L}$ & $<1 \mu \mathrm{g} / \mathrm{L}$ \\
\hline Benzeno & $665 \mu \mathrm{g} / \mathrm{L}$ & ND & $160 \mu \mathrm{g} / \mathrm{L}$ & ND \\
\hline Clorofórmio & $86 \mu \mathrm{g} / \mathrm{L}$ & ND & $88 \mu \mathrm{g} / \mathrm{L}$ & ND \\
\hline Fenol & ND & ND & ND & ND \\
\hline Pentaclorofenol & $437 \mu \mathrm{g} / \mathrm{L}$ & ND & $275 \mu \mathrm{g} / \mathrm{L}$ & ND \\
\hline Tetracloreto de carbono & $<1 \mu \mathrm{g} / \mathrm{L}$ & ND & $<1 \mu \mathrm{g} / \mathrm{L}$ & ND \\
\hline Tetracloroetileno & $<1 \mu \mathrm{g} / \mathrm{L}$ & ND & $<1 \mu \mathrm{g} / \mathrm{L}$ & ND \\
\hline Tolueno & $38 \mu \mathrm{g} / \mathrm{L}$ & $2 \mu g / L$ & $129 \mu \mathrm{g} / \mathrm{L}$ & $2 \mu g / L$ \\
\hline Tricloroeteno & $47 \mu \mathrm{g} / \mathrm{L}$ & ND & $77 \mu \mathrm{g} / \mathrm{L}$ & $<1 \mu \mathrm{g} / \mathrm{L}$ \\
\hline o-Xileno & ND & ND & ND & ND \\
\hline$m$-Xileno & $<1 \mu \mathrm{g} / \mathrm{L}$ & $<1 \mu \mathrm{g} / \mathrm{L}$ & ND & $3 \mu \mathrm{g} / \mathrm{L}$ \\
\hline$p$-Xileno & $781 \mu \mathrm{g} / \mathrm{L}$ & $2 \mu \mathrm{g} / \mathrm{L}$ & $566 \mu \mathrm{g} / \mathrm{L}$ & ND \\
\hline
\end{tabular}

Os resultados demonstram indiscutivelmente que os compostos orgânicos voláteis foram detectados em concentrações mais expressivas no efluente final dos reatores alimentados com efluente da indústria química nas duas amostragens feitas em datas diferentes, apesar da impossibilidade dos ensaios com amostras do efluente puro. A não ocorrência do fenol em nenhuma amostragem deve-se ao fato da biomassa da estação de tratamento estar bem adaptada a esse composto, conforme observações de Costa et al. (1997) na estação de tratamento de esgotos de Barueri, São Paulo, o que permite concluir que pode ter sido totalmente biodegradado e que possui baixa relação com a toxicidade do efluente final, embora não se descarte a possibilidade do fenol ter implicações sobre outros processos biológicos. Além disso, de acordo com o relatório operacional da planta de tratamento (SABESP, 2008), nos doze meses precedentes às data de análise das amostras do efluente final da estação, os níveis de fenol detectados no esgoto de entrada tem sido muito baixos, inclusive muito aquém ao estabelecido pelas 
Legislações que estipulam limites de fenol no lançamento de efluentes em corpos receptores (SMA, 1976; CONAMA, 2005).

Outros compostos, como 1,1-dicloroeteno, tetracloreto de carbono e tetracloroetileno foram detectados apenas nos reatores alimentados com o efluente industrial e em concentrações abaixo do limite de quantificação do método analítico. Como não foi possível a análise de amostras do efluente industrial para detecção de tais compostos, não é possível determinar se a não ocorrência no efluente final deve-se à volatilização, biodegradação, adsorção no floco biológico ou à não ocorrência do composto no próprio efluente industrial. Alguns compostos, como tetracloroetileno e tetracloreto de carbono podem ser convertidos, durante sua biodegradação, a diversos compostos, dentre os quais, 1,2-dicloroetano (PARSONS et al., 1984) e clorofórmio (DEBEST et al., 1998), respectivamente, compostos detectados em concentrações elevadas no efluente final. Dessa forma, como tais compostos não foram detectados, ou detectados em concentrações extremamente baixas, infere-se que possuem baixa implicação com a toxicidade do efluente final da estação de tratamento, ao passo que os demais compostos aparentemente confirmam seu caráter tóxico.

Dentre os isômeros de xileno, o para-xileno foi detectado em concentrações mais elevadas no efluente final da indústria química. O composto é utilizado por muitas indústrias na síntese de ácido tereftálico, que, dentre outras aplicações, é empregado na fabricação de garrafas $P E T$ e na produção de monômeros para síntese de polímeros. Sabe-se que uma das unidades fabris que compõem a indústria química avaliada no presente estudo é produtora de polímeros, embora não se saiba qual a composição, tanto dos insumos quanto do produto final. Todavia, a presença mais expressiva de $p$-xileno somente no biorreator que recebeu o efluente industrial é um indicativo de que há produção ou a substância é resultante da utilização de outros compostos no processo industrial.

\subsection{Ensaios de toxicidade, desempenho operacional e poluentes orgânicos no efluente final da E.T.E.}

$\mathrm{Na}$ Tabela 10, a seguir, apresentam-se os resultados de análises de compostos orgânicos, comparadas com os resultados de turbidez e eficiência de remoção de DQO e nitrogênio amoniacal (SABESP, 2008), e toxicidade aos 
organismos Daphnia similis e Vibrio fischeri, realizados nas amostras reais do efluente final da estação de tratamento de esgotos:

Tabela 10 - Resultados de ensaios de remoção de DQO, turbidez, nitrogênio amoniacal, poluentes orgânicos e ensaios ecotoxicológicos em amostras do efluente final da ETE estudada durante eventos de inibição no sistema e sob operação normal.

\begin{tabular}{|c|c|c|c|c|c|c|c|c|}
\hline \multirow{2}{*}{$\begin{array}{l}\text { Situação operacional: } \\
\text { Parâmetros }\end{array}$} & \multicolumn{4}{|c|}{ Operação Normal } & \multicolumn{4}{|c|}{ Inibição no sistema } \\
\hline & & & & Média & & & & Média \\
\hline Remoção DQO (\%) & 88 & 80 & 84 & $84 \pm 4$ & 60 & 78 & 76 & $71 \pm 10$ \\
\hline Turbidez (mg/L) & 3,7 & 3,8 & 2,8 & $3 \pm 1$ & 21 & 47 & 35 & $34 \pm 13$ \\
\hline Amônia $\left(\mathrm{mgN}-\mathrm{NH}_{3} / \mathrm{L}\right)$ & 12 & 17 & 5 & $11 \pm 6$ & 26 & 28 & 34 & $29 \pm 4$ \\
\hline 1,1-dicloroeteno ( $\mu \mathrm{g} / \mathrm{L})$ & ND & ND & ND & -" & ND & 23 & ND & - \\
\hline 1,2-dicloroetano ( $\mu \mathrm{g} / \mathrm{L})$ & 15 & NR & 12 & $14 \pm 2$ & 793 & 623 & 587 & $668 \pm 110$ \\
\hline Benzeno $(\mu \mathrm{g} / \mathrm{L})$ & $<1$ & $<1$ & 16 & - & 65 & 18 & ND & $28 \pm 34$ \\
\hline clorofórmio ( $\mu \mathrm{g} / \mathrm{L})$ & 0,07 & ND & $<1$ & - & 10 & 77 & 26 & $38 \pm 35$ \\
\hline pentaclorofenol $(\mu \mathrm{g} / \mathrm{L})$ & NR & ND & ND & - & 93 & 20 & 93 & $69 \pm 42$ \\
\hline tetracloreto de carbono $(\mu \mathrm{g} / \mathrm{L})$ & ND & ND & ND & - & 6 & ND & ND & - \\
\hline tetracloroetileno $(\mu \mathrm{g} / \mathrm{L})$ & ND & 3 & ND & - & 1,2 & 1,2 & 1,0 & $1,1 \pm 0,1$ \\
\hline tolueno $(\mu \mathrm{g} / \mathrm{L})$ & $<1$ & 12 & 67 & $27 \pm 36$ & 30 & 46 & 3 & $26 \pm 22$ \\
\hline tricloroeteno $(\mu \mathrm{g} / \mathrm{L})$ & ND & $<1$ & ND & - & 137 & 111 & 23 & $90 \pm 60$ \\
\hline$p$-Xileno $(\mu \mathrm{g} / \mathrm{L})$ & ND & 1,5 & 99 & $34 \pm 57$ & 354 & 56 & 35 & $148 \pm 178$ \\
\hline Toxicidade a D. similis (U.T.) & N.T. & N.T. & 2,1 & - & 28,6 & 33,3 & 12,8 & $25 \pm 11$ \\
\hline Toxicidade a $V$. fischeri (U.T.) & N.T. & 1,1 & 2,6 & - & 83,3 & 58,8 & 32,2 & $58 \pm 26$ \\
\hline
\end{tabular}

$\mathrm{NR}=$ Ensaio não realizado

$\mathrm{ND}=$ não detectado

N.T. = não tóxico

Conforme pode ser observado na Tabela 10, os mesmos poluentes detectados no efluente da indústria química ocorreram no efluente final da estação de tratamento de esgotos em três momentos distintos em que houve inibição no sistema. Também se observa o elevado grau de toxicidade no efluente final, o que foi confirmado pelos ensaios realizados com os organismos Daphnia similis e Vibrio fischeri. Em outras três ocasiões nas quais não houve inibição no sistema tais compostos simplesmente não foram detectados, o que confirma suas correlações com situações de inibição no processo de tratamento.

Comparando-se os dados de orgânicos com os parâmetros que são utilizados diariamente na estação de tratamento de esgotos para avaliação do processo, remoção de Demanda Química de Oxigênio e Turbidez, observa-se que em relação ao primeiro, não é possível estabelecer uma correlação, pois tanto em situações de 
inibição quanto em condições normais de operação, poucas vezes há interferência na remoção de DQO. Esse fato ocorre corriqueiramente na estação de tratamento, provavelmente devido ao fato da biomassa estar adaptada aos diferentes compostos tóxicos oriundos de inúmeras indústrias que despejam na estação e, dessa forma, não interferirem na composição microbiana responsável pela remoção de matéria orgânica propriamente. Conforme pode ser observado na Tabela 10, os valores relativos à eficiência de remoção de DQO em situação de inibição foram, em média, apenas $15 \%$ inferiores a media dos valores de remoção de DQO em situações de operação normal.

A nitrificação sofreu um impacto mais significativo, a média da eficiência de remoção de nitrogênio amoniacal das amostragens feitas durante os eventos de inibição, foi $38 \%$ menor em comparação às amostragens feitas sem inibição no sistema. Conforme já demonstrado por diversos autores (HOCKENBURY e GRADY, 1977; VANROLLEGHEM et al., 1996; COSTA et al., 1997; BAEYENS et al., 2003) o processo de nitrificação é um dos mais sensíveis no sistema de lodos ativados, sendo esta sensibilidade provocada por uma grande diversidade de compostos orgânicos e inorgânicos. A sensibilidade observada no presente trabalho também foi verificada por Komori et al. (2003), que avaliaram o efeito de compostos orgânicos voláteis sob duas condições de baixa temperatura em duas plantas de tratamento piloto, sendo uma alimentada com os poluentes e a outra não, e concluíram que a queda na eficiência de remoção de nitrogênio foi observada apenas na planta alimentada com os compostos, sendo que os efeitos se intensificaram sob baixa temperatura, provavelmente devido a efeitos sinérgicos.

Em relação aos dados de turbidez, estes foram mais condizentes com as duas situações operacionais da planta de tratamento. Verificou-se que, na medida em que situações de inibição ocorrem, a turbidez do efluente final da estação é um dos primeiros parâmetros a sofrer interferência. De acordo com os dados, a turbidez aumentou, em média, $90 \%$ nas situações de inibição do processo. Apesar de não ser um parâmetro normalmente utilizado para controle de estações de tratamento de esgotos, a turbidez é uma excelente ferramenta para avaliar a eficiência do processo, pois pode indicar, dentre outros itens, a concentração de sólidos em suspensão (JORDAO, 1995). A Figura 9, a seguir, exibe o efluente final da estação de tratamento durante um evento de inibição, no qual a turbidez se mostrava elevada, e durante normalidade no sistema (operação normal). 

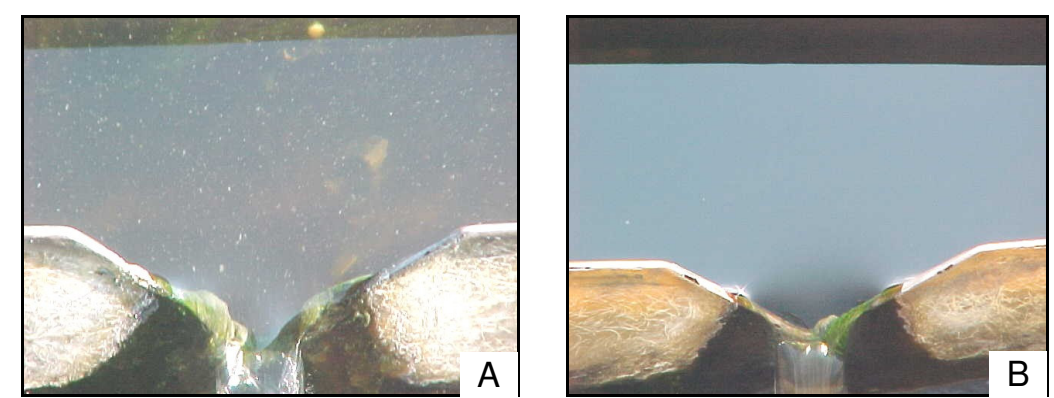

Figura 9 - Fotografias da calha do vertedor do efluente final tratado da ETE objeto de estudo em dois momentos: A) com inibição no processo e elevada turbidez; B) sem inibição no processo (operação normal).

\subsection{Isolamento e seleção dos microrganismos}

\subsubsection{Obtenção das linhagens}

Foram isoladas inicialmente 104 linhagens bacterianas em 7 fontes de carbono diferentes. As fontes de carbono foram selecionadas a partir dos resultados dos ensaios que demonstraram que tais compostos exerciam influência na toxicidade do efluente final da estação de tratamento. Esse resultado demonstra o alto potencial microbiológico do sistema de lodos ativados para isolamento e seleção de microrganismos capazes de degradar compostos tóxicos. A Tabela 11, a seguir, exibe a quantidade total de UFC's, quantidade de linhagens isoladas por fonte de carbono:

Tabela 11 - Densidade total de microrganismos (UFC/mL) por fonte de carbono, código de identificação das linhagens e número de microrganismos isolados por fonte de carbono

\begin{tabular}{lccc}
\hline $\begin{array}{l}\text { Fonte de } \\
\text { carbono }\end{array}$ & UFC/mL & $\begin{array}{c}\text { Identificação } \\
\text { das linhagens }\end{array}$ & $\begin{array}{c}\text { Quantidade } \\
\text { de isolados }\end{array}$ \\
\hline Benzeno & $3,35 \times 10^{6}$ & BEN & 15 \\
Clorofórmio & $1,76 \times 10^{7}$ & CLF & 17 \\
1,2-dicloroetano & $3,30 \times 10^{5}$ & DCE & 13 \\
Pentaclorofenol & $2,67 \times 10^{7}$ & PCF & 20 \\
Tolueno & $1,43 \times 10^{8}$ & TOL & 16 \\
Tricloroeteno & $2,74 \times 10^{6}$ & TCE & 12 \\
Xileno & $7,20 \times 10^{6}$ & XIL & 11 \\
\hline
\end{tabular}




\subsubsection{Crescimento de isolados utilizando diferentes fontes de carbono}

Das 104 linhagens isoladas, foram selecionadas 73 para avaliação de crescimento em meio mínimo contendo o poluente como única fonte de carbono. Os resultados das curvas estão expressos nos gráficos das Figuras 10 a 16 . 0 crescimento das colônias em placas de Petri contendo meio Agar nutriente, realizado ao final do experimento, confirmou que nenhuma linhagem sofreu contaminação durante esta etapa do trabalho.

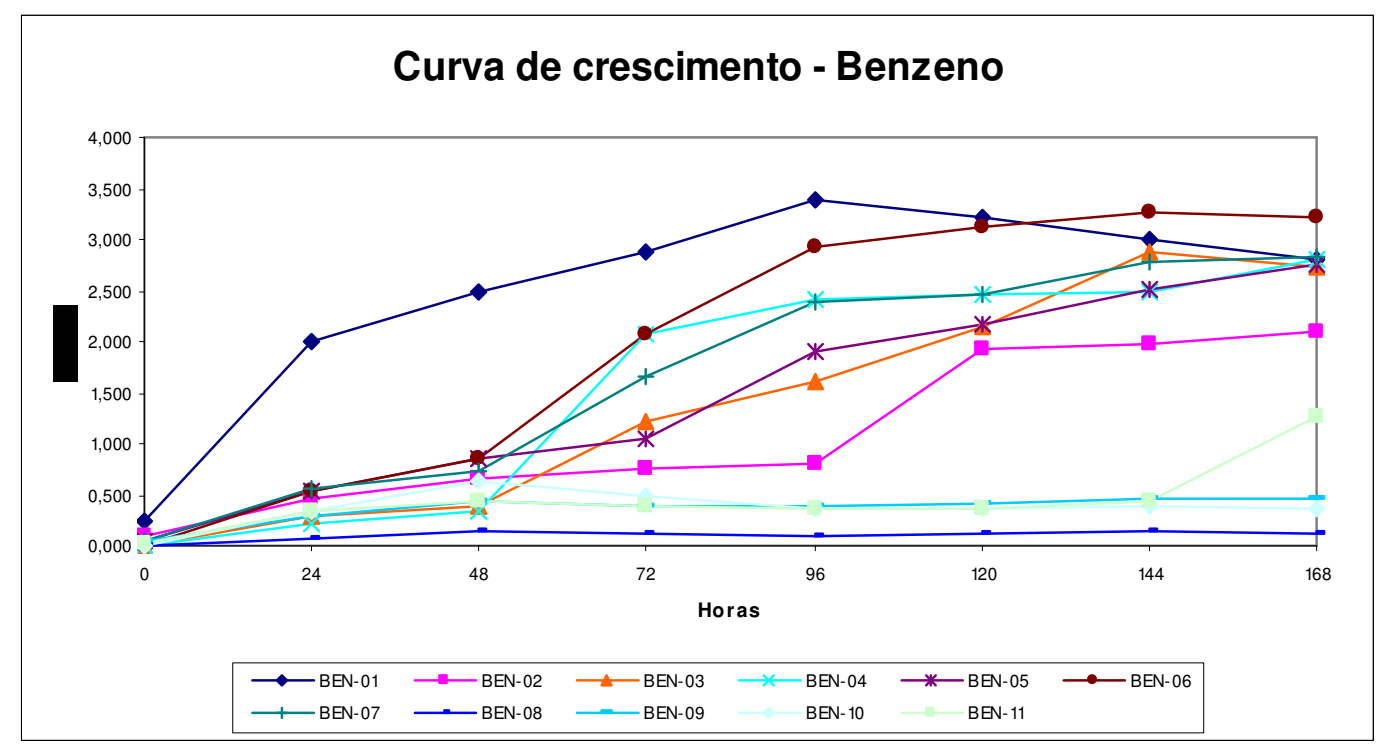

Figura 10 - Crescimento de isolados bacterianos em meio mínimo contendo benzeno como única fonte de carbono.

De acordo com as curvas de crescimento, dentre as linhagens degradadoras de benzeno, as que atingiram os valores máximos de absorbância foram, na seqüência, as linhagens BEN-01, BEN-06, BEN-03 e BEN-07. Entretanto, apesar de apresentar uma queda de $17 \%$ após atingir seu crescimento máximo, a linhagem BEN-01 foi selecionada por ser a única a exibir uma fase de adaptação muito curta, já iniciando a fase log nos primeiros dias de cultivo. A linhagem BEN-06 atingiu o segundo maior valor de crescimento. As linhagens BEN-03 e BEN-07 apresentaram curvas muito semelhantes, porém a linhagem BEN-07 foi selecionada porque em sua curva persistiu uma tendência ao crescimento mesmo após a leitura de 168 horas. Em termos gerais, a maior parte das linhagens atingiu valores de absorbância entre 2,500 e 3,500 durante a biodegradação do benzeno, um composto que apresenta alta toxicidade e que pode gerar compostos igualmente tóxicos 
dependendo da via de biodegradação (ARVIN et al., 1989). Das onze linhagens testadas, apenas quatro não apresentaram esse padrão de crescimento.

O benzeno é um dos compostos mais largamente utilizados pela indústria química avaliada no presente estudo. Supõe-se, assim, que seja um dos compostos que cheguem à estação de tratamento de esgotos em concentração mais elevada. Entretanto, a presença de outros substratos, como tolueno e xileno, por exemplo, podem estimular sua oxidação, conforme já demonstrado por Arvin et al. (1989). Cabe ressaltar que conforme citado por Bouwer e McCart (1984), e Scheunert (1992), a degradação de elementos orgânicos traços não suporta o crescimento microbiano, sendo necessária a presença de uma fonte de carbono mais facilmente biodegradável. Alguns autores tem demonstrado que a presença de outros substratos intensifica a biodegradação do benzeno, embora o oposto também possa ocorrer. A ocorrência desses efeitos sinérgicos estar associada à baixa concentração de benzeno detectada no efluente final da estação de tratamento, em comparação com os demais poluentes considerados no trabalho. Entretanto, essa afirmação contrapõe-se às condições em que os microrganismos cresceram durante este experimento, pois não havia outras fontes de carbono disponíveis e/ou outros microrganismos que pudessem suprir a falta de uma determinada enzima necessária para a completa degradação do composto. Como o crescimento microbiano ocorreu de maneira indiscutível, torna-se interessante um estudo mais aprofundado para esclarecer quais mecanismos possam ter sido ativados que permitiram às linhagens o seu crescimento.

Alvarez e Vogel (1991) avaliaram as taxas de biodegradação de bezeno, tolueno e p-xileno individualmente e em misturas, utilizando culturas puras de Pseudomonas sp. e Arthrobacter sp. Em Pseudomonas, houve aumento na degradação de benzeno na presença de tolueno, ao passo que a degradação do tolueno ocorreu de maneira mais eficiente quando o composto foi adicionado isoladamente do que junto com benzeno e/ou p-xileno. Curiosamente, Arthrobacter foi incapaz de degradar tolueno e p-xileno individualmente, o que ocorreu somente na presença de benzeno, sugerindo cometabolismo. Já a degradação de benzeno foi prejudicada pela presença de tolueno e/ou p-xileno, o que sugere inibição competitiva. Portanto, a variação qualitativa em relação à microbiota e compostos químicos presentes no esgoto afluente à estação de tratamento é um fator determinante na biodegradação ou não de um determinado composto, o que terá 
relação direto com o nível de toxicidade verificado posteriormente no efluente final da planta.

Conforme pode ser verificado nos resultados dos ensaios de detecção de poluentes orgânicos, o benzeno é um composto que está presente na água residuária industrial e também foi detectado no efluente final da estação de tratamento. Nas três amostragens feitas durante eventos de inibição, esteve presente em duas, bem como em uma amostragem feita durante uma das três condições de normalidade operação. Isso pode indicar que nem sempre o composto pode estar associado à inibição no sistema, não sendo possível o estabelecimento de uma correlação positiva entre a presença do composto e ocorrência de perturbação operacional, podendo ocorrer situações em que, mesmo presente, pode não haver tal ocorrência.

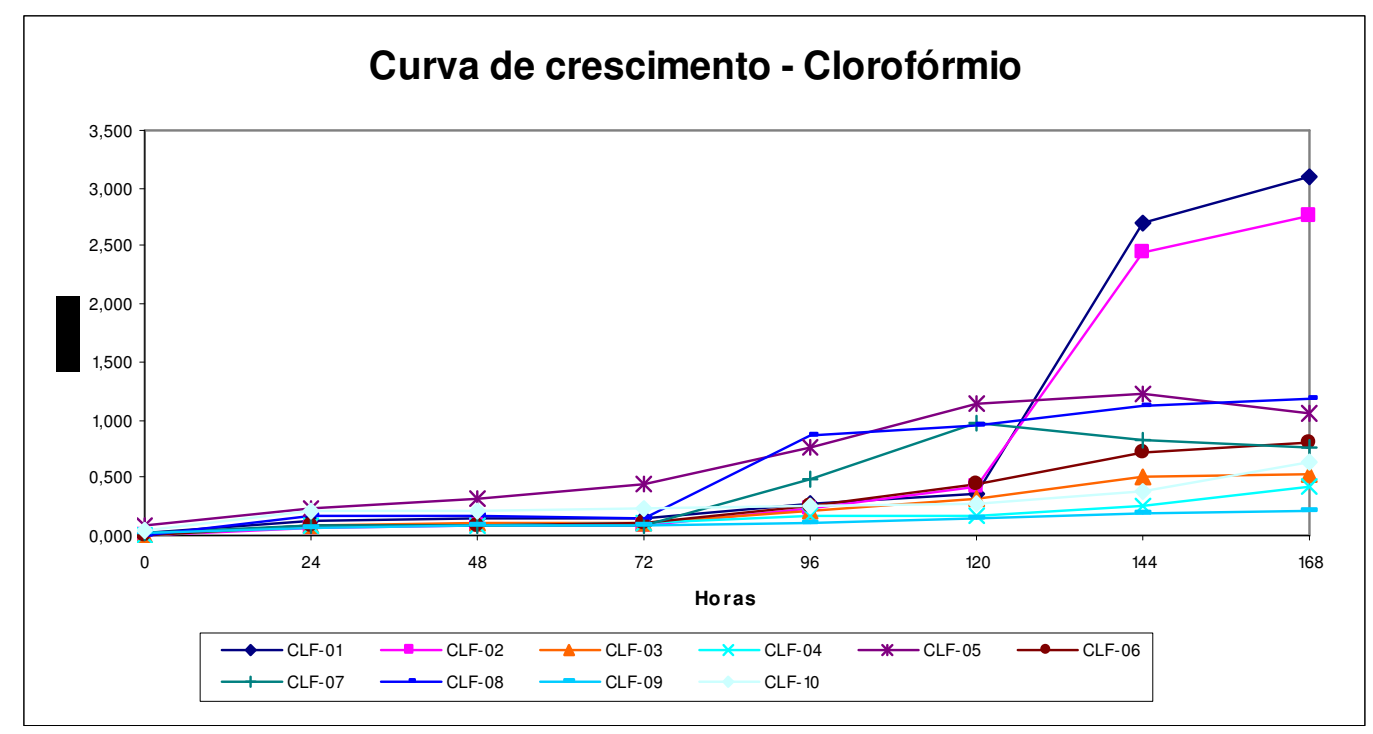

Figura 11 - Crescimento de isolados bacterianos em meio mínimo contendo clorofórmio como única fonte de carbono.

O crescimento das linhagens degradadoras de clorofórmio foi uniforme, exibindo uma fase lag, com algumas exceções, de até 72 horas. Este fato apóia-se em alguns estudos antigos que indicam que o clorofórmio é um composto muito persistente cuja biodegradabilidade é iniciada, sob condições aeróbias, após um longo período de adaptação (BOUWER et al., 1981; WILSON et al., 1981, 1983; BOUWER e MCCARTY, 1984). A biodegradação do clorofórmio ocorre mais frequentemente em meio anaeróbio por culturas metanogênicas (GOSSETT, 1985; COOK et al., 1987; HOGENKAMP, 1989; BOYD, 1990) e não metanogênicas (GALLI 
e MCCARTY, 1989; COOK et al., 1990; FATHEPURE e TIEDJE, 1994), mas em meio aeróbio sua biodegradação ocorre principalmente em processos de cometabolismo, principalmente por organismos metanotróficos (JANSSEN, et al., 1989; ALVAREZ-COHEN et al., 1992) e oxidantes de amônia (ARCIERO et al., 1990). Igualmente ao que foi observado em relação às linhagens degradadoras de benzeno, é necessário uma maior elucidação quanto às vias relacionadas com a biodegradação do clorofórmio, pois durante o crescimento em laboratório as linhagens cresceram tendo somente o composto como fonte de carbono.

As linhagens CLF-01 e CLF-02 apresentaram resultados que se diferenciaram muito das demais, atingindo picos de crescimento 95 e 97\%, respectivamente, mais elevado em relação às leituras registradas em 72 horas. Inclusive, mesmo na ultima leitura a tendência de crescimento ainda era crescente. A linhagem CLF-05 atingiu o terceiro maior pico de crescimento e iniciou a fase log antes das demais, entretanto, a linhagem CLF-08 foi selecionada porque exibiu uma fase log mais acentuada, seguida de outra crescente, ao passo que a CLF-05 iniciou uma leve fase de declínio após 144 horas, embora o crescimento dessas duas últimas tenha sido bastante inferior às linhagens CLF-01 e CLF-2.

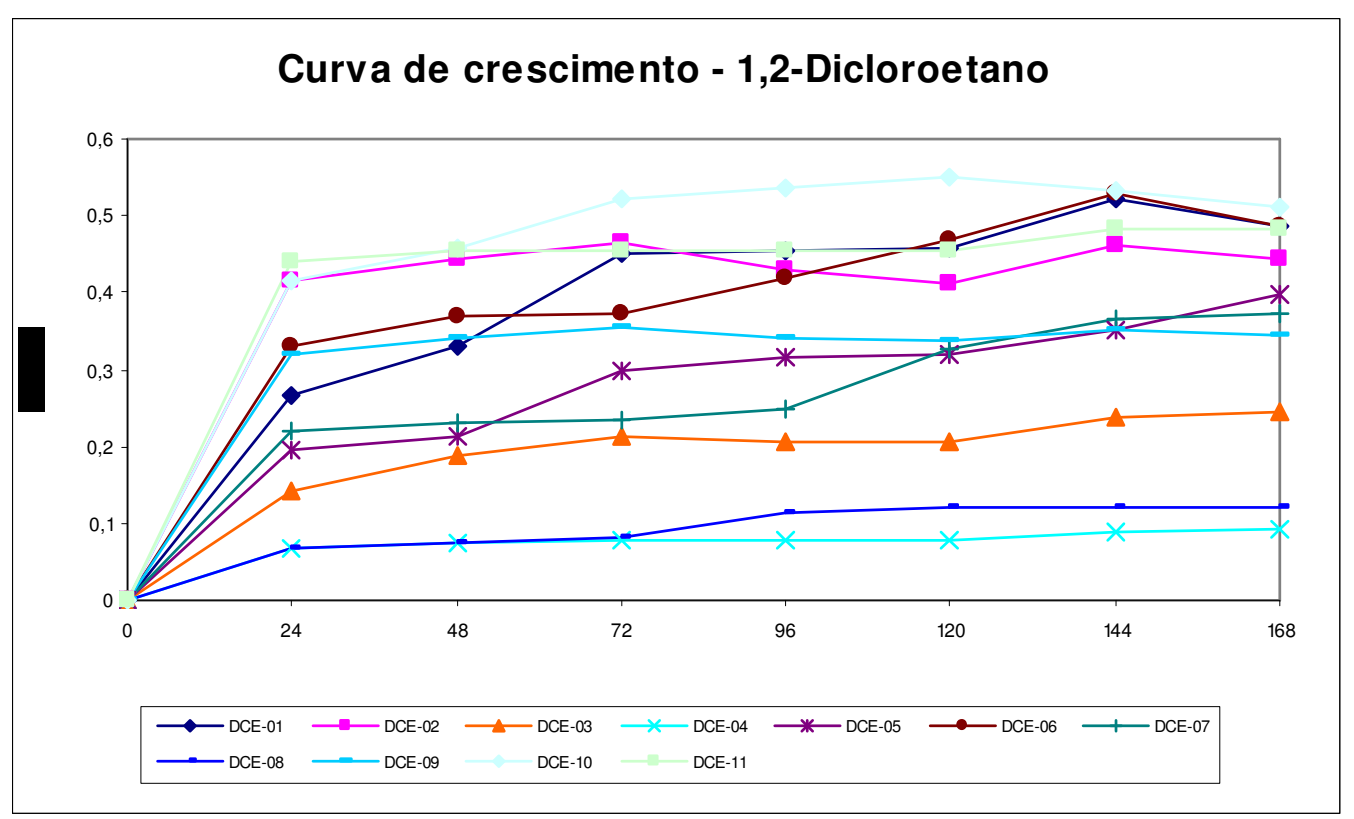

Figura 12 - Crescimento de isolados bacterianos em meio mínimo contendo 1,2-dicloroetano como única fonte de carbono.

As linhagens degradadoras de 1,2-dicloroetano apresentaram, de um modo geral, um crescimento menos expressivo, sendo que cinco linhagens exibiram 
curvas de crescimento bastante semelhantes, cujos valores máximos de absorbância oscilaram entre 0,400 e 0,600. Todas iniciaram uma fase de declínio a partir do sexto dia de crescimento. Foram selecionadas as linhagens DCE-01, DCE06 e DCE-10. Devido ao pequeno crescimento observado para estas linhagens, outros isolamentos de microrganismos capazes de degradar 1,2-dicloroetano foram tentados. Entretanto, as curvas de crescimento foram, na média, inferiores às registradas pelas linhagens aqui apresentadas.

A via de degradação de 1,2-dicloroetano mais comumente estudada, do microrganismo Xanthobacter autotrophicus GJ10 (HAGE, 1999), inicia-se com a conversão do composto a 2-cloroetanol e posterior formação de cloroacetaldeído (UNIVERSITY OF MINNESOTA, 2008), um composto altamente tóxico ao meio. De acordo com Janssen et al. (1995), a toxicidade é minimizada pela expressão de enzimas pelo próprio microrganismo utilizado para biodegradação ou por outros presentes no meio. Provavelmente, o baixo crescimento das linhagens nessa fonte de carbono pode estar relacionado ou à elevada toxicidade desse ou de outro composto intermediário formado, ou mesmo pela falta de outros microrganismos que garantissem a diversidade metabólica requerida para o pleno crescimento da linhagem, que cresceu isoladamente.

O 1,2-dicloroetano é altamente tóxico para ecossistemas aquáticos, tendo sido alvo de grande preocupação quanto suas implicações ambientais (COOK e DICKINSON, 2004). O composto é difícil de ser removido por métodos físicoquímicos tradicionais, sendo a biodegradação praticamente a única alternativa (MILEVA et al., 2008). Diferentes linhagens dos gêneros Xanthobacter, Pseudomonas e Ancylobacter tem se mostrado capazes de degradar o composto.

Sua ocorrência tanto no efluente da indústria química quanto no esgoto afluente e efluente da estação de tratamento objeto de estudo já vem sendo evidenciada desde meados dos anos 90, quando Pereira e Andrade (1997) realizaram um estudo sobre os compostos orgânicos voláteis presentes na estação e no efluente da mesma indústria química também objeto do presente trabalho. $\mathrm{Na}$ ocasião, observou-se que o 1,2-dicloroetano era o composto presente em concentração mais elevada tanto no esgoto de entrada quanto de saída, conforme Tabela 12, a seguir. 
Tabela 12 - Concentração $(\mu \mathrm{g} / \mathrm{L})$ dos compostos orgânicos presentes em diferentes pontos da estação de tratamento de esgotos objeto de estudo em 1997

\begin{tabular}{lcccc}
\hline Substância & Afluente & $\begin{array}{c}\text { Caixa de } \\
\text { Areia }\end{array}$ & $\begin{array}{c}\text { Tanque de } \\
\text { aeração }\end{array}$ & $\begin{array}{c}\text { Efluente } \\
\text { Final }\end{array}$ \\
\hline Benzeno & 937 & 610 & 4,4 & P.I. \\
Clorofórmio & 138 & 73 & 10 & 1,0 \\
1,2-dicloroetano & 1.118 & 1.042 & 750 & 729 \\
Tetracl. carbono & 23 & 7,5 & 2,0 & 2,0 \\
Tetracloroeteno & 80 & 37 & 2,1 & 2,0 \\
Tricloroeteno & 36 & 20 & 5,1 & 1,9 \\
Tolueno & 1.106 & 648 & 42 & 6,0 \\
Xileno & 950 & 560 & 42 & 0,5 \\
\hline
\end{tabular}

P.I. $=$ Presença de interferentes

Fonte: Pereira e Andrade (1997).

Coincidentemente, em todos os ensaios de cromatografia realizados no presente trabalho, as concentrações de 1,2-dicloroetano mostraram-se mais elevadas que a dos demais compostos. Isso sugere que desde o primeiro estudo realizado na mesma estação de tratamento de esgotos, realizado por Pereira e Andrade (1997) não houve mudança significativa na qualidade do esgoto afluente e efluente em relação a esse composto. Dessa forma, infere-se que este seja um dos elementos que possuem mais relação com as ocorrências de toxicidade observadas no efluente final da estação de tratamento. Esta situação pode ocorrer tanto pelas características químicas intrínsecas à própria molécula e seus efeitos exercidos sobre a biota aquática, quanto pelo simples fato de ocorrer em maior concentração e, portanto, possuir uma capacidade maior de causar toxicidade ao meio. 


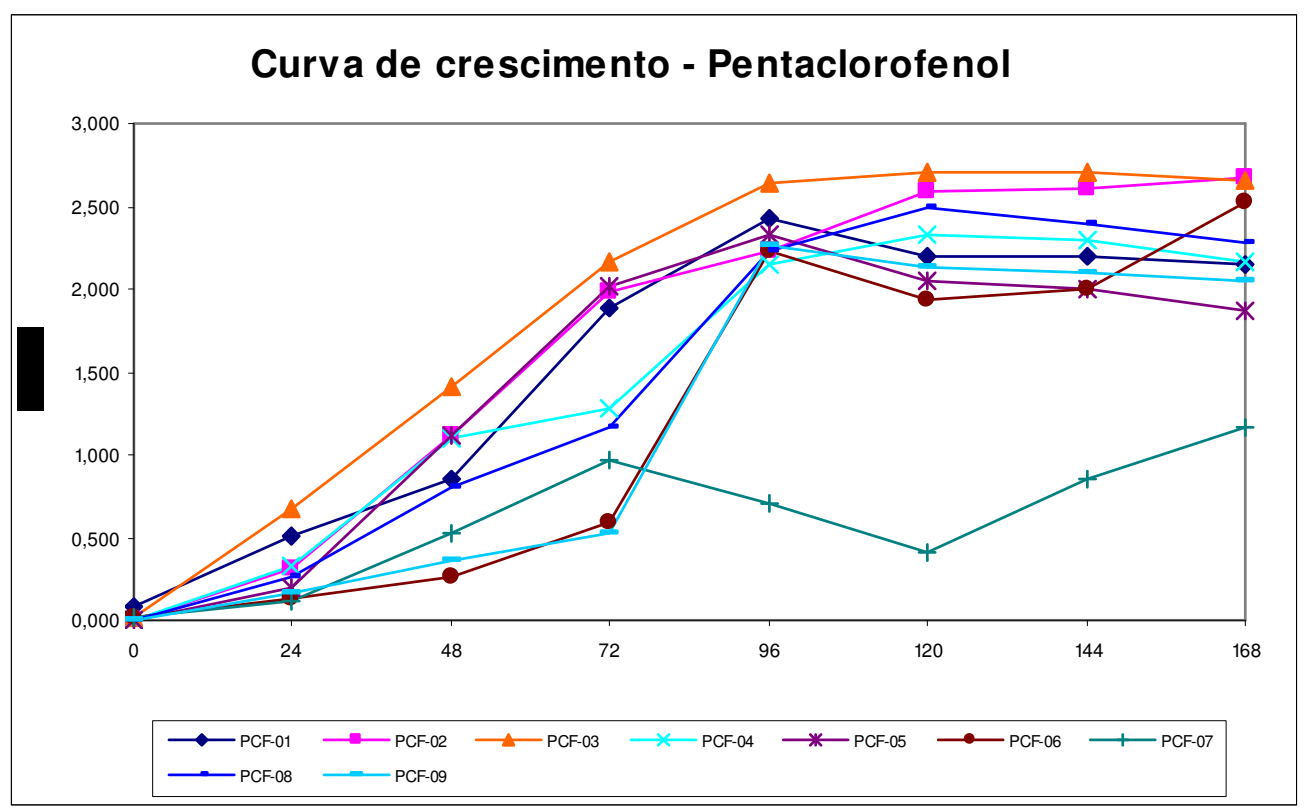

Figura 13 - Crescimento de isolados bacterianos em meio mínimo contendo pentaclorofenol como única fonte de carbono.

O pentaclorofenol é um composto que apresenta elevada recalcitrância, entretanto, desde os anos 70 são reportados em literatura diversos experimentos de biodegradação do composto com diferentes gêneros bacterianos, como Arthrobacter, Corynebacterium, Flavobacterium, Pseudomonas, Rhodococcus e Sphingomonas, bem como com os fungos Phanerochaete e Trichoderma (CASSIDY et al., 1997), embora nem todas tenham capacidade de degradar o composto completamente, inclusive há determinadas espécies que geram metabólitos ainda mais tóxicos, e outras que não toleram qualquer alteração nas condições físicoquímicas do meio, conforme demonstrado por Wolski et al. (2006).

Com exceção da linhagem PCF-07, todos os microrganismos que cresceram em pentaclorofenol apresentaram valores máximos que, comparando-se com os padrões de crescimento observados em algumas das outras fontes de carbono, podem ser considerados satisfatórios. Os microrganismos que exibiram as curvas de crescimento mais acentuadas atingiram densidades óticas entre 2,266 e 2,713. Entretanto as linhagens PCF-03, PCF-02 e PCF-06 atingiram, na seqüência, valores indiscutivelmente mais consistentes do que as demais, sendo que a linhagem PCF03 praticamente não exibiu fase lag e atingiu o pico máximo de crescimento em 96 horas. Curiosamente, a linhagem PCF-06 também atingiu seu pico nesse mesmo tempo, contudo, seu crescimento foi sucedido por uma queda de $14 \%$ na absorbância seguida por um aumento após 48 horas em 24\%. Uma provável 
explicação para tal fenômeno pode ser a formação de algum composto intermediário tóxico para a linhagem durante a via de degradação do pentaclorofenol, pois tal efeito foi observado inclusive na linhagem PCF-07.

As rotas de biodegradação do pentaclorofenol mais conhecidas, estudadas nos microrganismos Flavobacterium sp. (FETZNER e LINGENS, 1994), Sphingomonas chlorophenolica (XUN et al., 2002) e em Burkholderia cepacia (UNIVERISTY OF MINNESOTA, 2008) se inicia com a formação de 2,3,5,6tetraclorohidroquinona por ação da enzima pcp-monooxigenase, o qual é convertido posteriormente em 2,3,6-triclorohidroquinona, seguida de 2,6-hidroquinona e 2monohidroquinona por hidrogenases redutoras glutationa-dependentes. Conforme descrito por McGrath e Singleton (2004), mais de 30 produtos são formados durante a degradação de pentaclorofenol, muitos dos quais apresentando toxicidade mais elevada do que o composto original, como o tri e o tetraclorofenol. Esse fato pode estar associado ao comportamento de algumas linhagens durante o período de incubação observado no gráfico da Figura 13. A formação desses ou de outros prováveis compostos pode ter submetido às linhagens a necessidade de readaptação sempre que cada novo composto era formado. Gonzales e Wei Shou (1995) já haviam demonstrado um comportamento similar em experimento utilizando diferentes linhagens bacterianas do gênero Flavobacterium degradadoras de pentaclorofenol. Algumas não foram capazes de resistir ao período de adaptação ao passo que outras continuaram capazes de crescer e degradar o composto. Nesse trabalho, o autor também concluiu que a concentração do poluente influencia na adaptação microbiana. 


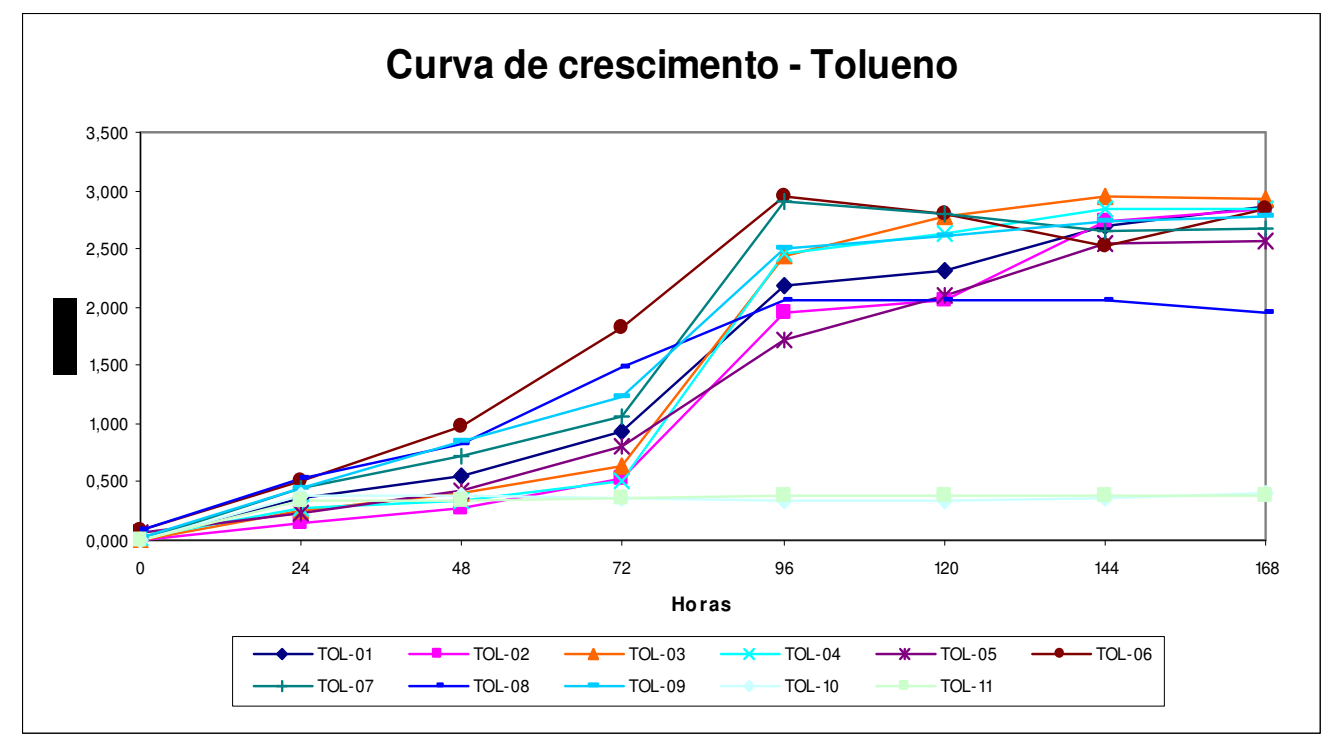

Figura 14 - Crescimento de isolados bacterianos em meio mínimo contendo tolueno como única fonte de carbono.

Na natureza o tolueno não é biodegradado rapidamente e apresenta elevada toxicidade, aparentemente devido à interação do composto com a membrana citoplasmática bacteriana, levando à perda de cátions $\mathrm{Mg}^{2+} \mathrm{e} \mathrm{Ca}^{2+}$, bem como outras moléculas menores (DESMET ${ }^{9}$ et al., 1983 apud NAHAR et al., 2000). Portanto, é considerado um composto inibitório ao crescimento bacteriano, embora muitas bactérias com capacidade de degradação do composto tenham sido isoladas (NAHAR et al., 2000), principalmente pertencentes ao gênero Pseudomonas, além da espécie Aeromonas caviae, isolada de amostra de lodo ativado por Nahar e Quilty, (1999).

As curvas de crescimento das linhagens degradadoras de tolueno demonstram comportamentos similares. A maioria apresentou um crescimento mediano até 72 horas de cultivo. Nas 24 ou 48 horas seguintes sofreram uma explosão populacional, culminando em picos máximos de crescimento. $\mathrm{O}$ desempenho mais significativo foi da linhagem TOL-06, que praticamente não experimentou fase lag, iniciando um crescimento exponencial que pôde ser observado já nas primeiras leituras. A linhagem TOL-03 despontou para um aumento de 74\% nas 24 horas seguintes ao iniciar a fase exponencial. Após esse período, a velocidade de crescimento reduziu-se, mas ainda com tendência crescente. A

\footnotetext{
9 DESMET, M. J.; KINGMA, J.; WYNBERG, H.; WITHOTT, B. Pseudomonas oleovorans as a tool in bioconversion of hydrocarbons: growth, morphology and conversion characteristics in different two-phase systems. Enzyme and Microbial Technology, v. 5, p. 352-360, 1983.
} 
terceira linhagem selecionada foi a TOL-07, que atingiu o terceiro maior valor de absorbância. A linhagem TOL-01 também exibiu uma curva bastante semelhante à TOL-07, entretanto não foi selecionada por atingir um pico menor que a TOL-07.

Os primeiros relatos de biodegradação de tolueno foram registrados em 1908, quando foi verificada a habilidade da bactéria Bacillus hexavarbovorum em crescer aerobicamente em tolueno e xileno (GIBSON e SUBRAMANIAN ${ }^{10}, 1984$ apud ALVAREZ e HUNT, 2002). O tolueno é um composto com elevada capacidade de ativação de enzimas oxigenase, o que tem relação com o fato da sua presença ocasionalmente estimular a biodegradação de outros compostos, como benzeno, etilbenzeno e isômeros de xileno (ARVIN et al., 1989; ALVAREZ e VOGEL, 1991), apesar de alguns estudos indicarem que o tolueno pode inibir a biodegradação do benzeno e do fenol (TRIGUEIROS, 2008). Aparentemente esse é o mecanismo que explica o fato da presença do composto estimular a degradação de outros elementos, como se o tolueno agisse como uma espécie de primeiro substrato para os microrganismos. Dessa forma, é de se esperar que a biodegradação do composto isolado ocorra sem dificuldades. As curvas do gráfico da Figura 14 confirmam, de certa forma, tal afirmação, pois apenas duas das onze linhagens não foram capazes de crescer em meio contendo tolueno como única fonte de carbono.

Em relação à ocorrência do composto atualmente na planta de tratamento, os índices detectados no efluente final da estação são considerados baixos em relação aos demais compostos analisados. No trabalho realizado por Pereira e Andrade em 1997, o nível de tolueno detectado no esgoto afluente à estação de tratamento era o segundo mais alto dentre os compostos orgânicos avaliados na ocasião, menor somente que o valor do 1,2-dicloroetano, entretanto, sua concentração no efluente final da planta era extremamente baixa, o que confirma que o composto sofreu uma grande redução ao entrar na estação de tratamento. Obviamente que, por se tratar de um composto altamente volátil, não se pode atribuir a sua redução apenas à biodegradação, mas é possível inferir que paralelamente ocorre uma elevada taxa de remoção devido à atividade microbiológica.

10 GIBSON, D. T.; SUBRAMANIAN, V. Microbial degradation of aromatic hydrocarbons. In: DEKKER, M. Microbial Degradation of Organic Compounds. New York: Gibson Ed., 1984. p. 181-252. 


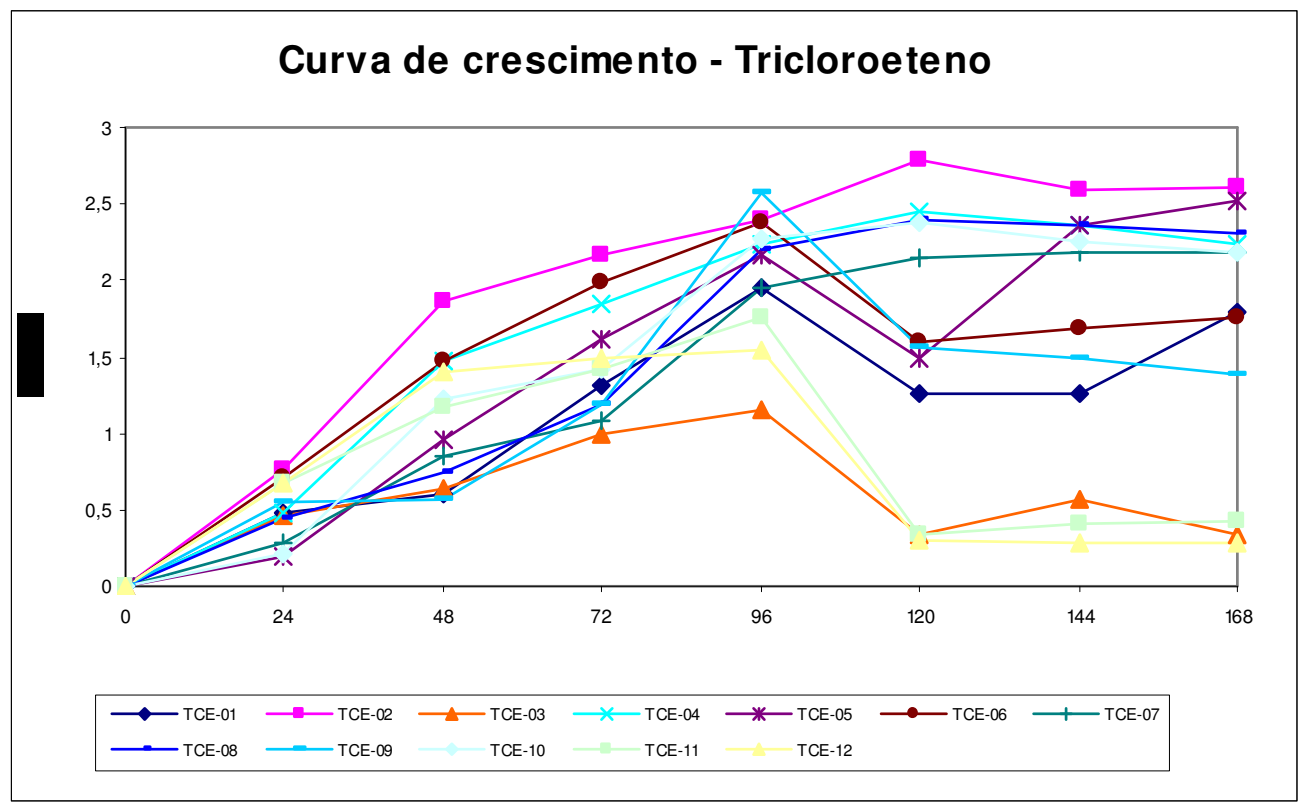

Figuras 15 - Crescimento de isolados bacterianos em meio mínimo contendo tricloroeteno como única fonte de carbono.

Todas as linhagens degradadoras de tricloroeteno atingiram valores máximos de crescimento entre 96 e 120 horas, sendo que sete linhagens sofreram queda acentuada após essa fase. Uma das possíveis causas para tal efeito pode estar associada à toxicidade do dicloroacetato, formado a partir da ação da enzima tolueno-1,2-dioxigenase, que age sobre uma grande variedade de substratos, dentre os quais o tricloroeteno, e é expressa por muitos microrganismos, dentre os quais, Burkholderia e Pseudomonas (UNIVERSITY OF MINNESOTA, 2008), sendo este último gênero muito comum em sistemas de lodos ativados. A linhagem TCE-02 apresentou a melhor performance, seguida da linhagem TCE-05, que foi uma das linhagens que sofreram queda após 96 horas de cultivo, porém recuperando sua tendência crescente em $41 \%$ entre o quinto e o sétimo dia. Em termos de valores absolutos, a linhagem TCE-09 atingiu o segundo maior crescimento em 96 horas. Entretanto, sofreu um declínio semelhante à linhagem TCE-05, porém sem recuperar-se. Nesse caso, essa linhagem não foi selecionada, e sim a linhagem TCE-08, cuja curva de crescimento se mostrou regularmente crescente.

De acordo com Kocamemi e Çeçen (2007), os microrganismos que utilizam o tricloroeteno como fonte de carbono, o fazem por mecanismos de cometabolismo, tanto em meio aeróbio quanto em meio anaeróbio, através da ação de enzimas não específicas sintetizadas pelas bactérias que utilizam os demais substratos. Até o momento, as bactérias aeróbias capazes de cometabolizar o tricloroeteno são 
degradadoras de metano (ALVAREZ-COHEN et al., 1992), propano (CHANG e ALVAREZ-COHEN, 1995), tolueno (CHANG e ALVAREZ-COHEN, 1995), fenol (NAKANO et al., 1999) e nitrificantes (KOCAMENI e ÇEÇEN, 2007). No caso dessas últimas, sua ação adquire uma importância de bastante relevância, uma vez que microrganismos nitrificantes estão normalmente presentes em elevada densidade em estações de tratamento de esgotos. Dessa forma um estudo mais detalhado seria necessário para esclarecer a biodegradação do composto quando ele é a única fonte de carbono disponível, de acordo com as condições do experimento de avaliação do crescimento.

Arciero et al., (1989) foram os primeiros a demonstrar o cometabolismo do tricloroeteno por Nitrosomonas europaea, sugerindo que o composto exerce ação de inibidor competitivo sobre a amônia monooxigenase, principal enzima responsável pela nitrificação em E.T.E.s (HOCKENBURY e GRADY, 1977; CHENG et al., 1996; BAEYENS et al., 2003). Conforme demonstrado por Ely et al. (1995), o tricloroeteno se mostrou um potente inibidor competitivo da oxidação de amônia por $N$. europaea. No estudo realizado por Baeyens et al. (2003), 0,65 mg/L de tricloroeteno foi suficiente para inibir o processo de nitrificação em $50 \%$. Sob uma concentração de 1 $\mathrm{mg} / \mathrm{L}$ a inibição chegou a $80 \%$. Os mesmos autores observaram também que para não haver nenhuma interferência sobre o processo de nitrificação, a concentração de tricloroeteno deve situar-se abaixo de 0,5 mg/L.

Dessa forma, seria importante um controle da entrada de tricloroeteno na estação de tratamento uma vez que, ao passo que visivelmente não haveria problemas para sua biodegradação em função da presença e atividade dos microrganismos nitrificantes, as concentrações de tricloroeteno citadas anteriormente poderiam inibir o processo de nitrificação, o que pode sujeitar a planta ao não cumprimento do que é estabelecido pelo Artigo 34 da Resolução CONAMA 357 em relação ao parâmetro nitrogênio amoniacal - $20 \mathrm{mgN}-\mathrm{NH}_{3} / \mathrm{L}$ para 0 lançamento de efluentes em corpos receptores. Cabe ressaltar, entretanto, que essa mesma legislação é a que limita a concentração de tricloroeteno a 1,0 mg/L. 


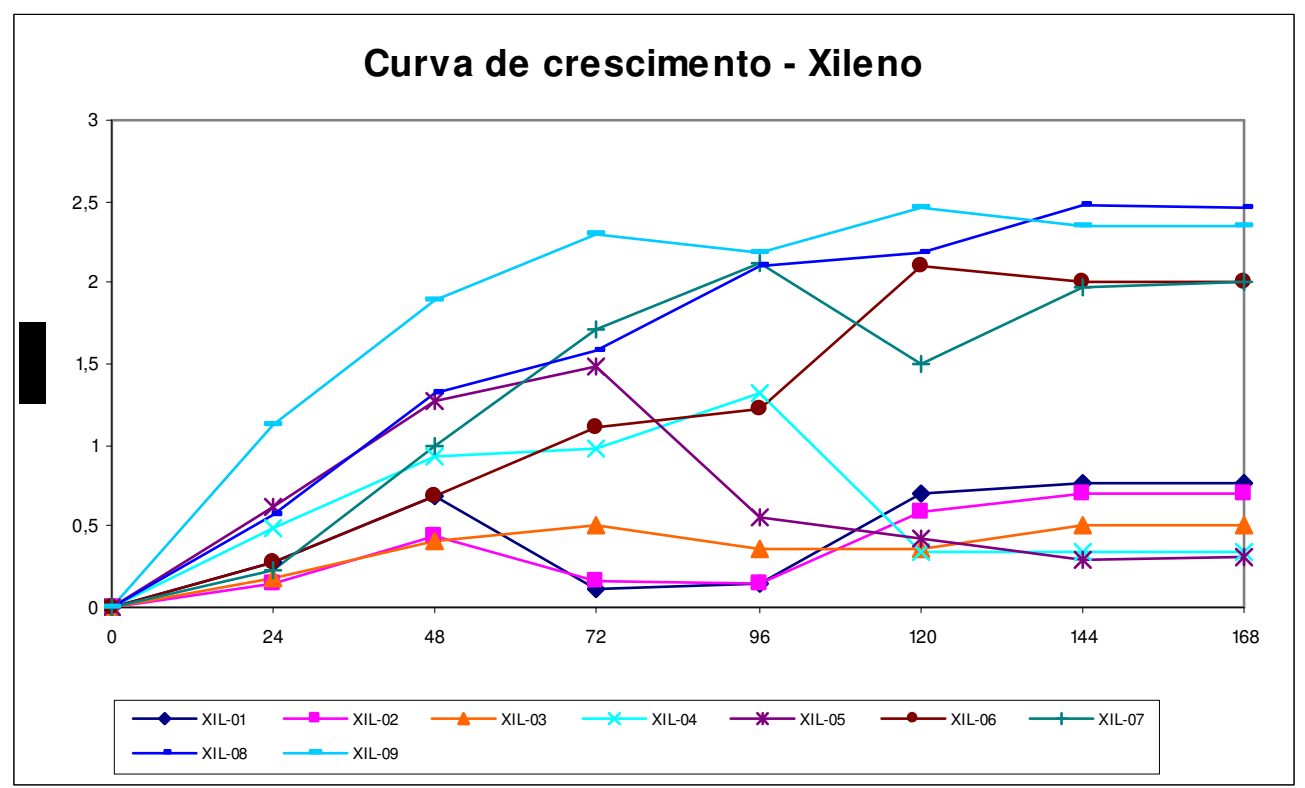

Figura 16 - Crescimento de isolados bacterianos em meio mínimo contendo p-xileno como única fonte de carbono.

Com exceção das linhagens XIL-06, XIL-08 e XIL-09, todas as degradadoras de p-xileno sofreram redução acentuada na população entre 48 e 96 horas, sempre após atingir um pico máximo de crescimento. Novamente, atribui-se esse efeito à possível formação de compostos tóxicos durante a degradação do composto, o que sujeita as linhagens à readaptação. De acordo com a via de degradação mais comum de p-xileno, estudada em Pseudomonas putida (UNIVERSITY OF MINNESOTA, 2008), organismo muito comum em sistemas de lodos ativados (BUSSE e SEILER, 1978 apud HAMER, 1997; KAPPESSER et al., 1989 apud HAMER, 1997) há formação de diversos metabólitos que são bioconvertidos pelo próprio organismo ou por outros presentes no meio. Shen et al. (2000), avaliou oito metabólitos originados durante a degradação de compostos aromáticos, dentre os quais o xileno, e destacou dois metabólitos: 3-metilcatecol e 4-metilcatecol que apresentaram elevada citotoxidade. Ao se observar as curvas do gráfico da Figura 16, é possível inferir que tal efeito pode ter sido um dos responsáveis pelo baixo crescimento em mais de $50 \%$ das linhagens degradadoras de p-xileno avaliadas, uma vez que, crescendo isoladamente, não havia interação com outros microrganismos que pudessem utilizar esses compostos. Provavelmente as linhagens que obtiveram maior sucesso de crescimento foram as que possuíam um melhor aporte enzimático, o que permitiu metabolizar os metabólitos intermediários tóxicos originados durante a biodegradação, ou as que ativaram outras vias de 
degradação do composto, conforme publicado por Jang et al. (2005), que utilizando a cepa YU6 de Rhodococcus sp. demonstrou que a linhagem é capaz de metabolizar o composto através da oxidação do anel aromático e clivagem na posição para. Inclusive o trabalho de Jan foi o primeiro a demonstrar uma linhagem microbiana capaz de degradar os três isômeros de xileno, pois as bactérias que possuem capacidade de degradar esse composto são normalmente divididas em dois grupos: as que degradam $m$ - e $p$-xileno e as que degradam o-xileno.

Dessa forma, apenas algumas linhagens, como XIL-01, XIL-02, XIL-03 e XIL07 aparentemente adaptaram-se relativamente bem ao novo composto presente, visto que após esse período de queda, apresentam crescimento acentuado, em alguns casos atingindo picos ainda maiores do que os registrados anteriormente. No entanto, outras linhagens, como XIL-04 e XIL-05 sofrem severa redução e não se recuperam mais. Portanto, as três linhagens que não sofreram tal efeito foram selecionadas.

\subsection{Pré tratamento do efluente industrial (Teste A)}

\subsubsection{Resultados dos ensaios físico-químicos}

Nas tabelas 13 a 18, a seguir, apresentam-se os dados dos ensaios de $\mathrm{pH}$, Demanda Química de Oxigênio, Sólidos em Suspensão Totais, Sólidos Sedimentáveis, Nitrogênio Amoniacal, Surfactantes e Fenol, nas amostras do efluente industrial antes e depois do pré tratamento com ou sem (controle) a introdução dos consórcios microbianos.

Tabela 13 - Resultados de $\mathrm{pH}$ do efluente industrial antes e depois do pré-tratamento com ou sem (controle) a introdução dos consórcios microbianos.

\begin{tabular}{lccc}
\hline \multicolumn{1}{c}{ AMOSTRA } & pH AFL. & pH EFL. & Variação (\%) \\
\hline CONTROLE & $6,3 \pm 0,5$ & $7,4 \pm 0,9$ & 15 \\
\hline BEN & 6,3 & 6,9 & 9 \\
CLF & 6,3 & 6,5 & 3 \\
DCE & 6,3 & 7,2 & 13 \\
PCF & 6,3 & 8,4 & 25 \\
TCE & 6,3 & 7,0 & 10 \\
TOL & 6,3 & 6,3 & 0 \\
XIL & 6,3 & 7,9 & 20 \\
\hline
\end{tabular}

Controle $=$ sem bioaumentação

BEN, CLF, DCE, PCF, TCE, TOL e XIL = bioaumentação com adição de diferentes consórcios microbianos. 
Tabela 14 - Resultados de DQO do efluente industrial antes e depois do pré-tratamento com ou sem (controle) a introdução dos consórcios microbianos.

\begin{tabular}{lccc}
\hline \multicolumn{1}{c}{ AMOSTRA } & $\begin{array}{c}\text { DQO AFL. } \\
\left(\mathbf{m g O}_{\mathbf{2}} \mathbf{L}\right)\end{array}$ & $\begin{array}{c}\text { DQO EFL. } \\
\left(\mathbf{m g O}_{\mathbf{2}} \mathbf{L}\right)\end{array}$ & $\begin{array}{c}\text { Variação } \\
(\%)\end{array}$ \\
\hline CONTROLE & $3.012,3 \pm 427$ & $1708,0 \pm 85$ & 43 \\
\hline BEN & $3.012,3$ & 2000,8 & 34 \\
CLF & $3.012,3$ & 1998,2 & 34 \\
DCE & $3.012,3$ & 2643,8 & 12 \\
PCF & $3.012,3$ & 2265,9 & 25 \\
TCE & $3.012,3$ & 1833,0 & 39 \\
TOL & $3.012,3$ & 2244,0 & 26 \\
XIL & $3.012,3$ & 1099,9 & 63 \\
\hline
\end{tabular}

Controle $=$ sem bioaumentação

BEN, CLF, DCE, PCF, TCE, TOL e XIL = bioaumentação com adição de diferentes consórcios microbianos.

Tabela 15 - Resultados de SS do efluente industrial antes e depois do pré-tratamento com ou sem (controle) a introdução dos consórcios microbianos.

\begin{tabular}{lccc}
\hline \multicolumn{1}{c}{ AMOSTRA } & $\begin{array}{c}\text { SS AFL. } \\
(\mathbf{m L S S} / \mathbf{L})\end{array}$ & $\begin{array}{c}\text { SS EFL. } \\
(\mathbf{m L S S} / \mathbf{L})\end{array}$ & $\begin{array}{c}\text { Variação } \\
(\%)\end{array}$ \\
\hline CONTROLE & $27,3 \pm 4$ & $2,6 \pm 2$ & 90 \\
BEN & 27,3 & 5,0 & 82 \\
CLF & 27,3 & 4,7 & 83 \\
DCE & 27,3 & 10,9 & 60 \\
PCF & 27,3 & 8,5 & 69 \\
TCE & 27,3 & 2,7 & 90 \\
TOL & 27,3 & 3,3 & 88 \\
XIL & 27,3 & 3,0 & 89 \\
\hline
\end{tabular}

Controle $=$ sem bioaumentação

BEN, CLF, DCE, PCF, TCE, TOL e XIL = bioaumentação com adição de diferentes consórcios microbianos.

Tabela 16 - Resultados de nitrogênio amoniacal do efluente industrial antes e depois do prétratamento com ou sem (controle) a introdução dos consórcios microbianos.

\begin{tabular}{lccc}
\hline \multicolumn{1}{c}{ AMOSTRA } & $\begin{array}{c}\text { Amônia AFL. } \\
\left(\mathbf{m g N}_{\mathbf{N}} \mathbf{N H}_{\mathbf{3}} \mathbf{L}\right)\end{array}$ & $\begin{array}{c}\text { Amônia EFL. } \\
\left(\mathbf{m g N}_{\mathbf{N}} \mathbf{N H}_{\mathbf{3}} / \mathbf{L}\right)\end{array}$ & $\begin{array}{c}\text { Variação } \\
(\%)\end{array}$ \\
\hline CONTROLE & $273,4 \pm 14$ & $131,2 \pm 3$ & 52 \\
BEN & 273,4 & 95,7 & 65 \\
CLF & 273,4 & 72,9 & 73 \\
DCE & 273,4 & 119,0 & 56 \\
PCF & 273,4 & 87,4 & 68 \\
TCE & 273,4 & 55,8 & 80 \\
TOL & 273,4 & 70,1 & 74 \\
XIL & 273,4 & 64,6 & 76 \\
\hline
\end{tabular}

Controle $=$ sem bioaumentação

BEN, CLF, DCE, PCF, TCE, TOL e XIL = bioaumentação com adição de diferentes consórcios microbianos. 
Tabela 17 - Resultados de surfactantes do efluente industrial antes e depois do pré-tratamento com ou sem (controle) a introdução dos consórcios microbianos.

\begin{tabular}{lccc}
\hline AMOSTRA & $\begin{array}{c}\text { ATA AFL. } \\
\text { (mgLAS/L) }\end{array}$ & $\begin{array}{c}\text { ATA EFL. } \\
\text { (mgLAS/L) }\end{array}$ & $\begin{array}{c}\text { Variação } \\
(\%)\end{array}$ \\
\hline CONTROLE & $3,6 \pm 0,3$ & $0,9 \pm 0,02$ & 75 \\
BEN & 3,6 & 0,1 & 97 \\
CLF & 3,6 & 0,3 & 92 \\
DCE & 3,6 & 3,0 & 17 \\
PCF & 3,6 & 0,8 & 78 \\
TCE & 3,6 & 0,8 & 78 \\
TOL & 3,6 & 1,1 & 69 \\
XIL & 3,6 & $<0,1$ & 99 \\
\hline
\end{tabular}

Controle $=$ sem bioaumentação

BEN, CLF, DCE, PCF, TCE, TOL e XIL = bioaumentação com adição de diferentes consórcios microbianos.

Tabela 18 - Resultados de fenol do efluente industrial antes e depois do pré-tratamento com ou sem (controle) a introdução dos consórcios microbianos.

\begin{tabular}{lccc}
\hline \multicolumn{1}{c}{ AMOSTRA } & $\begin{array}{c}\text { FENOL AFL. } \\
\left(\mathrm{mgC}_{5} \mathrm{H}_{6} \mathrm{OH} / \mathrm{L}\right)\end{array}$ & $\begin{array}{c}\text { FENOL EFL. } \\
\left(\mathrm{mgC}_{5} \mathrm{H}_{6} \mathrm{OH} / \mathrm{L}\right)\end{array}$ & $\begin{array}{c}\text { Variação } \\
(\%)\end{array}$ \\
\hline CONTROLE & $3,5 \pm 0,7$ & $<0,1605$ & 99,9 \\
BEN & 3,5 & $<0,1605$ & 99,9 \\
CLF & 3,5 & 0,6 & 83,0 \\
DCE & 3,5 & 1,2 & 66,0 \\
PCF & 3,5 & $<0,1605$ & 99,9 \\
TCE & 3,5 & $<0,1605$ & 99,9 \\
TOL & 3,5 & $<0,1605$ & 99,9 \\
XIL & 3,5 & $<0,1605$ & 99,9 \\
\hline
\end{tabular}

Controle $=$ sem bioaumentação

BEN, CLF, DCE, PCF, TCE, TOL e XIL = bioaumentação com adição de diferentes consórcios microbianos.

Os parâmetros operacionais avaliados em paralelo com os ensaios ecotoxicológicos permitiram uma observação quanto à importância da aplicação de tecnologias de pré tratamento para o recebimento de efluentes oriundos de fontes não domésticas na rede coletora de esgotos. Uma observação menos detalhada já é suficiente para a conclusão de que, de maneira geral, a presença do consórcio microbiano representou uma melhor eficiência na remoção dos compostos analisados, embora tais parâmetros não sejam ameaças hoje para a estação de tratamento vir a ser alvo de infrações por parte do órgão fiscalizador ambiental. Entretanto, o acompanhamento de tais parâmetros juntamente com os ensaios ecotoxicológicos são importantes para que se evidencie ainda mais a importância de um monitoramento que não compreenda apenas parâmetros físico-quimicos e viceversa.

Comparando-se com o biorreator controle, a remoção de DQO se mostrou menos eficiente nos biorreatores nos quais os consórcios microbianos foram 
adicionados, exceto no biorreator que recebeu o consórcio XIL. Esses dados inesperados podem estar relacionados a fatores intrínsecos à atividade microbiana, uma vez que a adição de microrganismos cria inquestionavelmente uma situação de desequilíbrio em relação às condições originais e os processos passam a adquirir novas configurações. A presença do consórcio PCF, por exemplo, resultou na alcalinização do meio, o que pode se tornar inibitório à atividade de determinados grupos microbianos, embora, de uma maneira geral, as mudanças de $\mathrm{pH}$ para valores mais extremos não tenha acontecido com nenhum outro consórcio, portanto, não sendo possível correlacionar mudanças de $\mathrm{pH}$ com a eficiência reduzida na remoção de matéria orgânica. Outros parâmetros que também foram prejudicados pela presença dos microrganismos do consórcio foram a remoção de sólidos sedimentáveis, no qual somente um biorreator teve eficiência similar ao controle, todos os outros foram inferiores, e a remoção de surfactantes, onde apenas dois biorreatores, nos quais foram adicionados os consórcios TOL e XIL, se mostraram mais eficientes do que o biorreator controle.

O processo de nitrificação, que é realizado por microrganismos reconhecidamente mais sensíveis, conforme já apresentado por Hockenbury e Grady apud Baeyens et al. (2003) e Vanrolleghem et al. (1996), foi otimizado pelos consórcios microbianos. Em todos os reatores bioaumentados a eficiência de remoção foi superior ao controle, conforme pode ser observados na Tabela 16. Este fato pode estar relacionado com o fato dos microrganismos do consórcio terem reduzido a presença de determinados contaminantes, permitindo que os microrganismos responsáveis pela nitrificação cumprissem seu papel. Contudo, questiona-se o motivo pelo qual tal fato não favoreceu, de um modo geral, os outros processos analisados.

A remoção de fenol mostrou-se nula com a adição dos inóculos, pois mesmo em condições controle, o composto foi reduzido ao ponto abaixo do limite de quantificação do método analítico, ou seja, sua remoção foi de praticamente $100 \%$. Nos reatores bioaumentados com os consórcios CLF e DCE a eficiência de remoção de fenol foi menor, contudo o nível detectado no efluente final ainda situava-se aquém do limite estabelecido pela legislação. Cabe ressaltar que o fenol é um poluente orgânico que raramente oferece riscos à estação de tratamento, pois de acordo com inúmeros testes já realizados na própria estação de tratamento (dados não publicados), a biomassa do sistema possui elevada adaptação ao composto. 
Os microrganismos constituintes dos consórcios certamente estão presentes no próprio efluente industrial, obviamente que em concentrações menores, pois naturalmente sofrem todos os tipos de interações ecológicas com os demais microrganismos, além da interferência dos fatores abióticos do meio. Torna-se difícil determinar com precisão quais os efeitos que o aumento considerável em suas densidades, ocasionado pela bioaumentação, pode acarretar ao biorreator. Determinados processos podem ser inibidos ou mesmo estimulados. Portanto, uma determinada resposta que se espera de uma determinada linhagem microbiana pode não acontecer. Um exemplo é o consórcio formado pelos microrganismos degradadores de 1,2-dicloroetano, composto que possui muitas implicações com as ocorrências de toxicidade, de acordo com os ensaios de cromatografia gasosa. Em tese, um consórcio que obtivesse sucesso na degradação desse composto tornaria o meio menos agressivo. Entretanto, os resultados dos ensaios físico-químicos indicam que, em relação aos parâmetros analisados, a presença desse consórcio significou, na maioria das vezes, redução da eficiência do biorreator. Comparativamente, observou-se redução de $72 \%$ na remoção de DQO, além de diminuição em outros parâmetros, como SS, surfactantes e fenol. O consórcio DCE também exibiu a menor eficiência, dentre os consórcios, de remoção de amônia.

Paradoxalmente, os consórcios BEN, CLF e XIL obtiveram altos níveis de degradação de surfactantes, em média, $22 \%$ superior ao controle. Os surfactantes são considerados os poluentes mais comuns no esgoto (METCALF \& EDDY, 2003) e sua presença na estação de tratamento sempre foi constante, uma vez que a indústria química é uma grande produtora de alquilbenzenos sulfonados ramificados (ABS) e lineares (LAS). Inclusive, no passado, os episódios de inibição no sistema quando do recebimento de efluentes com elevado teor de espumas eram freqüentes, porém, hoje, tais episódios são mais raros. Uma das possíveis explicações pode ser a adaptação dos microrganismos ao composto, uma vez que, de acordo com Costa et al. (2004), os surfactantes sofrem biodegradação por processos biológicos aeróbios e anaeróbios, uma vez que seja atingida a separação do radical alquila do anel benzeno sulfonado, o qual é degradado posteriormente a dióxido de carbono, sulfato e água. 


\subsubsection{Resultados dos ensaios de ecotoxicidade aguda}

As Tabelas 19 e 20, a seguir, apresentam os resultados dos ensaios ecotoxicológicos realizados com os microrganismos Daphnia similis e Vibrio fischeri, obtidos do primeiro teste de adição das linhagens microbianas isoladas no efluente industrial.

Tabela 19 - resultados dos ensaios de toxicidade para $D$. similis, expressos em Unidades Tóxicas, do efluente industrial antes $(A)$ e depois (B) da adição das linhagens microbianas puras, do efluente final $(C)$ dos reatores em batelada que simularam o tanque de aeração da E.T.E. e a comparação dos valores de toxicidade em relação ao efluente final do controle (D).

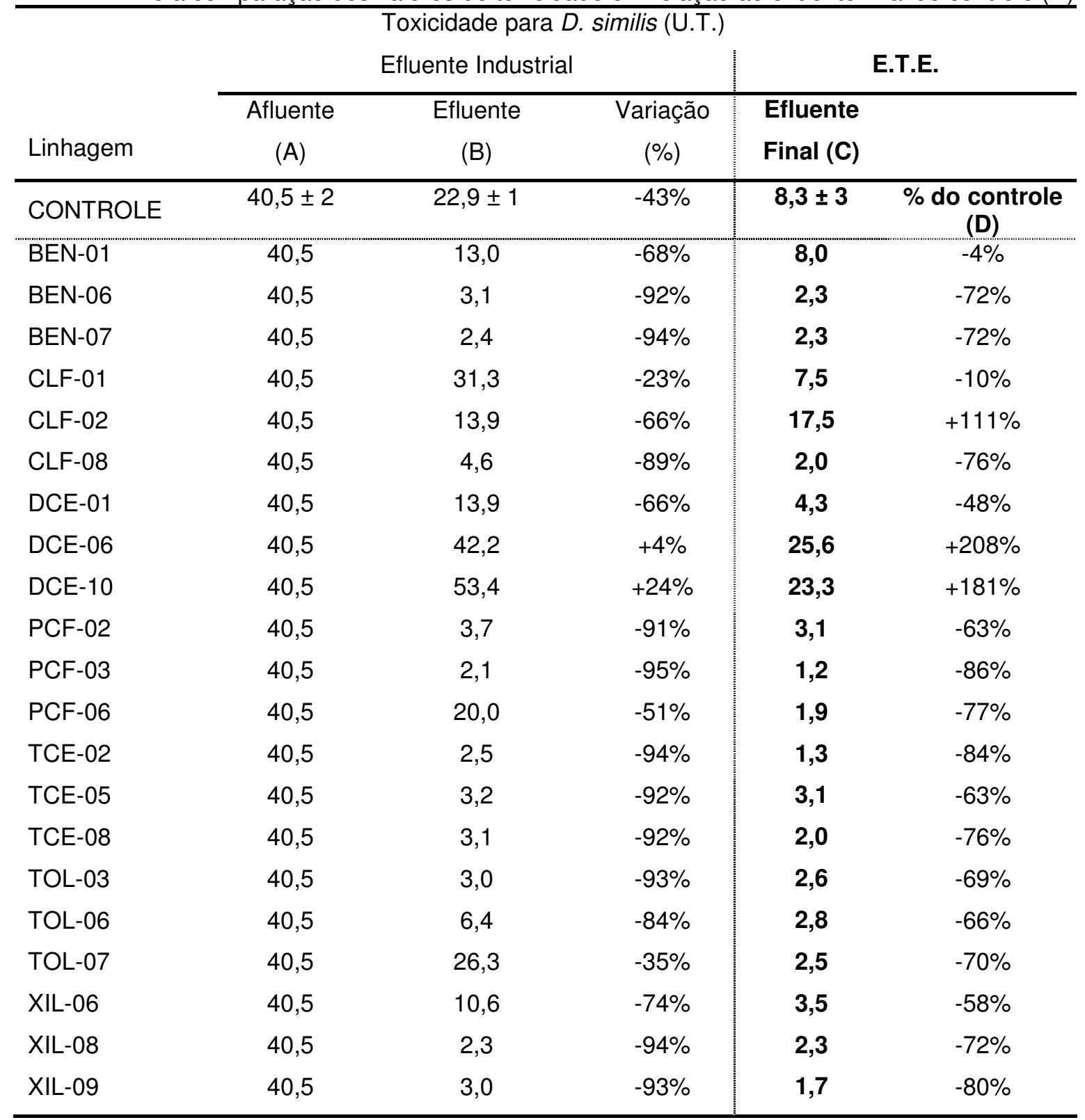


Tabela 20 - resultados dos ensaios de toxicidade para $V$. fischeri, expressos em Unidades Tóxicas, do efluente industrial antes (A) e depois (B) da adição das linhagens microbianas puras, do efluente final $(C)$ dos reatores em batelada que simularam o tanque de aeração da E.T.E. e a comparação dos valores de toxicidade em relação ao efluente final do controle (D).

\begin{tabular}{|c|c|c|c|c|c|}
\hline \multirow[b]{3}{*}{ Linhagem } & \multicolumn{4}{|c|}{ Toxicidade para $V$. fischeri (U.T.) } & \\
\hline & \multicolumn{3}{|c|}{ Efluente Industrial } & \multicolumn{2}{|c|}{ E.T.E. } \\
\hline & $\begin{array}{c}\text { Afluente } \\
\text { (A) }\end{array}$ & $\begin{array}{c}\text { Efluente } \\
\text { (B) }\end{array}$ & $\begin{array}{c}\text { Variação } \\
(\%)\end{array}$ & $\begin{array}{c}\text { Efluente } \\
\text { Final }\end{array}$ & \\
\hline CONTROLE & $89,3 \pm 22$ & $33,2 \pm 3$ & $-63 \%$ & $13,7 \pm 4$ & $\%$ do controle \\
\hline BEN-01 & 89,3 & 13,3 & $-85 \%$ & 8,3 & $-39 \%$ \\
\hline BEN-06 & 89,3 & 2,5 & $-97 \%$ & 2,4 & $-82 \%$ \\
\hline BEN-07 & 89,3 & 5,2 & $-94 \%$ & 2,9 & $-79 \%$ \\
\hline CLF-01 & 89,3 & 55,6 & $-38 \%$ & 6,5 & $-53 \%$ \\
\hline CLF-02 & 89,3 & 22,2 & $-75 \%$ & 6,3 & $-54 \%$ \\
\hline CLF-08 & 89,3 & 3,4 & $-96 \%$ & 2,3 & $-83 \%$ \\
\hline DCE-01 & 89,3 & 13,1 & $-85 \%$ & 2,7 & $-80 \%$ \\
\hline DCE-06 & 89,3 & 71,4 & $-20 \%$ & 12,4 & $-9 \%$ \\
\hline DCE-10 & 89,3 & 78,7 & $-12 \%$ & 13,7 & $0 \%$ \\
\hline PCF-02 & 89,3 & 6,0 & $-93 \%$ & 3,9 & $-72 \%$ \\
\hline PCF-03 & 89,3 & 1,7 & $-98 \%$ & 1,7 & $-88 \%$ \\
\hline PCF-06 & 89,3 & 3,2 & $-96 \%$ & 2,2 & $-84 \%$ \\
\hline TCE-02 & 89,3 & 1,9 & $-98 \%$ & 1,7 & $-88 \%$ \\
\hline TCE-05 & 89,3 & 4,7 & $-95 \%$ & 3,4 & $-75 \%$ \\
\hline TCE-08 & 89,3 & 3,1 & $-97 \%$ & 2,9 & $-79 \%$ \\
\hline TOL-03 & 89,3 & 3,6 & $-96 \%$ & 2,7 & $-80 \%$ \\
\hline TOL-06 & 89,3 & 9,0 & $-90 \%$ & 3,1 & $-77 \%$ \\
\hline TOL-07 & 89,3 & 4,7 & $-95 \%$ & 2,5 & $-82 \%$ \\
\hline XIL-06 & 89,3 & 5,4 & $-94 \%$ & 4,5 & $-67 \%$ \\
\hline XIL-08 & 89,3 & 3,4 & $-96 \%$ & 2,5 & $-82 \%$ \\
\hline XIL-09 & 89,3 & 2,3 & $-97 \%$ & 1,9 & $-86 \%$ \\
\hline
\end{tabular}

As Tabelas 21 e 22, a seguir, apresentam os resultados dos ensaios ecotoxicológicos obtidos a partir do segundo teste de bioaumentação do efluente industrial, realizado com consórcios microbianos especializados na degradação de compostos-alvo. 
Tabela 21 - resultados dos ensaios de toxicidade para $D$. similis, expressos em Unidades Tóxicas, do efluente industrial antes (A) e depois (B) da adição dos consórcios microbianos, do efluente final $(C)$ dos reatores em batelada que simularam o tanque de aeração da E.T.E. e a comparação dos valores de toxicidade em relação ao efluente final do controle (D).

\begin{tabular}{|c|c|c|c|c|c|}
\hline \multirow[b]{3}{*}{ Consórcio } & \multicolumn{4}{|c|}{ Toxicidade para $D$. similis (U.T.) } & \\
\hline & \multicolumn{3}{|c|}{ Efluente Industrial } & \multicolumn{2}{|c|}{ E.T.E. } \\
\hline & $\begin{array}{c}\text { Afluente } \\
\text { (A) }\end{array}$ & $\begin{array}{c}\text { Efluente } \\
\text { (B) }\end{array}$ & $\begin{array}{c}\text { Variação } \\
(\%)\end{array}$ & $\begin{array}{c}\text { Efluente } \\
\text { Final }\end{array}$ & \\
\hline CONTROLE & $111,1 \pm 66$ & $7,8 \pm 2$ & $-93 \%$ & $14,5 \pm 5$ & $\%$ do controle \\
\hline $\mathrm{BEN}$ & 111,1 & 1,3 & $-99 \%$ & N.T. & $-100 \%$ \\
\hline CLF & 111,1 & 1,5 & $-99 \%$ & N.T. & $-100 \%$ \\
\hline DCE & 111,1 & 1,8 & $-98 \%$ & 1,5 & $-90 \%$ \\
\hline PCF & 111,1 & N.T. & $-100 \%$ & 1,1 & $-92 \%$ \\
\hline TCE & 111,1 & 1,0 & $-99 \%$ & N.T. & $-100 \%$ \\
\hline TOL & 111,1 & 1,2 & $-99 \%$ & 1,1 & $-92 \%$ \\
\hline XIL & 111,1 & 1,7 & $-98 \%$ & N.T. & $-100 \%$ \\
\hline
\end{tabular}

N.T. = Não toxico

Tabela 22 - resultados dos ensaios de toxicidade para $V$. fischeri, expressos em Unidades Tóxicas, do efluente industrial antes (A) e depois (B) da adição dos consórcios microbianos, do efluente final (C) dos reatores em batelada que simularam o tanque de aeração da E.T.E. e a comparação dos valores de toxicidade em relação ao efluente final do controle (D).

\begin{tabular}{c|ccc|cc}
\hline \multirow{2}{*}{ Consórcio } & \multicolumn{3}{c}{ Toxicidade para V. fischeri (U.T.) } \\
& Efluente Industrial & \multicolumn{3}{c}{ E.T.E. } \\
\cline { 2 - 6 } & Afluente & Efluente & Variação & \multicolumn{2}{c}{ Efluente } \\
\hline CONTROLE & $333,3 \pm 51$ & $8,7 \pm 1,4$ & $97 \%$ & $\mathbf{5 , 2} \pm \mathbf{0 , 2}$ & $\%$ do controle \\
\hline BEN & 333,3 & 1,6 & $100 \%$ & $\mathbf{1 , 4}$ & $-73 \%$ \\
CLF & 333,3 & 2,2 & $99 \%$ & $\mathbf{1 , 1}$ & $-79 \%$ \\
DCE & 333,3 & 3,4 & $99 \%$ & $\mathbf{1 , 5}$ & $-71 \%$ \\
PCF & 333,3 & 1,6 & $100 \%$ & $\mathbf{1 , 4}$ & $-73 \%$ \\
TCE & 333,3 & 1,1 & $100 \%$ & $\mathbf{1 , 1}$ & $-79 \%$ \\
TOL & 333,3 & 1,6 & $100 \%$ & $\mathbf{1 , 3}$ & $-75 \%$ \\
XIL & 333,3 & 2,9 & $99 \%$ & $\mathbf{1 , 3}$ & $-75 \%$ \\
\hline
\end{tabular}

N.T. = Não toxico

Durante os testes de pré tratamento, foram analisados os parâmetros fisicoquímicos somente nos reatores bioaumentados com consórcios microbianos, em virtude do elevado número de ensaios que seriam necessários para todos os biorreatores nos quais foram feitos os testes com as linhagens puras. No entanto, os ensaios ecotoxicológicos foram realizados em todas as amostras de efluente final de 
todos os testes realizados, incluindo os que foram feitos com as linhagens microbianas puras, uma vez que a redução da toxicidade aguda do efluente final é o objetivo principal deste trabalho.

De acordo com os resultados do primeiro teste, em que foram adicionadas linhagens puras, observa-se que em todos os biorreatores houve redução da toxicidade do efluente industrial após o seu pré tratamento. Esse resultado já era esperado, pois apenas a aeração à qual as amostras foram submetidas ao longo das 36 horas do teste pode ocasionar a volatilização de muitos compostos tóxicos, além de intensificar a atividade microbiana em função da maior disponibilidade de oxigênio no meio. No reator controle, que não foi bioaumentado, a redução da toxicidade foi de $43 \%$ para $D$. similis e $63 \%$ para $V$. fischeri. Portanto, as linhagens realmente eficientes deveriam apresentar valores superiores ao observado no reator controle. De fato, na maioria dos reatores bioaumentados $(91 \%)$ registraram-se eficiências superiores de remoção de toxicidade para $D$. similis em relação ao reator controle. Em outros dois reatores, bioaumentados com as linhagens DCE-06 e DCE10, verificaram-se eficiências negativas, ou seja, a adição das linhagens resultou na geração de um efluente ainda mais tóxico. $\mathrm{Na}$ avaliação da toxicidade aguda para $V$. fischeri, $85 \%$ das linhagens tiveram desempenho superior ao controle, e as linhagens DCE-06 e DCE-10 novamente foram responsáveis por queda de eficiência dos reatores nos quais foram inoculadas. Curiosamente, a linhagem CLF-02, que reduziu a toxicidade para $D$. similis em $66 \%$, elevou a toxicidade para $V$. fischeri em $111 \%$. Novamente, atribui-se esses fatos à provável geração de metabólitos secundários mais tóxicos do que o composto original, como por exemplo os produtos intermediários da degradação de 1,2-dicloroetano, que podem exercer alguma influência na variação da toxicidade, uma vez que foi nos reatores com as linhagens degradadoras desse composto que foram observados os desempenhos menos significativos (Janssen et al., 1995; Hage, 1999, University of Minnesota, 2008)

A simples redução da toxicidade do efluente industrial durante o seu pré tratamento, mesmo que para níveis baixos, pode ainda sujeitar a estação de tratamento a lançar efluentes ainda tóxicos para o corpo receptor, pois o agente causador da toxicidade pode não ter desaparecido por completo. Esse efeito foi minimizado pela adição de algumas linhagens microbianas, que se mostraram eficientes na redução da toxicidade aguda, como por exemplo, as linhagens BEN-07, DCE-06, PCF-03 e TCE-02, que reduziram a toxicidade para D. similis, e BEN-06, 
DCE-01, DCE-06, PCF-03, TCE-02 e XIL-09 para V. fischeri. Entretanto, deve-se considerar que a remoção da toxicidade do efluente industrial não tem, nesse caso, um significado prático, uma vez que o efluente da indústria química avaliada no presente trabalho não é lançado diretamente em um corpo receptor. Assim, é o efluente final da estação de tratamento que o recebe o principal foco das atuações, pois esta se submete ao controle da legislação (CONAMA, 2005).

Dessa forma, avaliando os níveis de toxicidade do efluente final da E.T.E. simulada, 18 biorreatores (86\%) geraram efluente final menos tóxico para $D$. similis e 20 (95\%) para V. fischeri, ambos comparados ao biorreator controle. Os valores mais elevados foram observados nos reatores inoculados com as linhagens DCE-06 e DCE-10, para os dois organismos considerados no bioteste, além de CLF-02, para $D$ similis. Esses dados sugerem que os microrganismos adicionados podem ter desencadeado processos ainda na fase de pré tratamento do efluente industrial cujos resultados somente tornaram-se visíveis após o efluente industrial ter sido dosado na E.T.E. simulada, além disso, essas linhagens podem ter se multiplicado de tal forma no efluente industrial que, após atingirem a estação de tratamento, continuaram exercendo sua atividade removedora de toxicidade. Embora seja necessário destacar que nenhuma linhagem foi capaz de reduzir a toxicidade a zero, ou seja, em todos os casos, o efluente final da E.T.E. ainda estava tóxico.

Nos testes em que foram utilizados os consórcios microbianos, pôde-se analisar a correlação dos dados de toxicidade com os parâmetros operacionais. Apesar dos resultados dos ensaios fisico-químicos demonstrarem uma certa ineficiência em alguns biorreatores nos quais foram adicionados consórcios microbianos, o mesmo não se pode afirmar em relação à eficiência de remoção de toxicidade. Em todos os reatores bioaumentados com consórcios registraram-se eficiências superiores à condição controle, inclusive um consórcio em particular, o PCF, teve um excelente desempenho, reduzido a toxicidade do efluente industrial para $D$. similis a zero. Os ensaios de toxicidade para $V$. fischeri tiveram resultados correlatos, em todos os biorreatores a toxicidade tanto do efluente industrial tratado, quando do efluente final foram inferiores ao controle. Esses dados evidenciam a importância da avaliação toxicológica complementar aos ensaios físico-químicos. De acordo com Botta et al. (2008), os ensaios físico-químicos não são capazes de predizer os reais impactos que uma determinada substância ou efluente exercerá no meio ambiente. No presente trabalho essa afirmação se confirmou, pois apesar da 
maioria dos parâmetros físico-químicos apresentarem valores que satisfazem as exigências operacionais da estação de tratamento, os efluentes gerados apresentaram toxicidade. A adoção de dois organismos para os testes de toxicidade aguda também permitiu uma avaliação mais completa, pois conforme citado por Lapoli e Ribeiro (2002), não existe nenhum organismo totalmente sensível a todos os elementos potencialmente tóxicos presentes em uma água ou efluente, ou seja, quanto maior a amplitude de organismos empregados nos testes ecotoxicológicos, mais completa será a avaliação do agente.

Esses resultados confirmam a vantagem dos consórcios em relação às linhagens puras. Consórcios microbianos, por serem constituídos por mais de um organismo, dispõem, em tese, de um aparato enzimático mais diversificado, o que traz aos microrganismos diversas vantagens seletivas (DIAZ, 2004). Ainda que se tenham registrados traços de toxicidade em três reatores, a redução da toxicidade ocorreu de maneira bastante acentuada, tanto para $D$. similis quanto para $V$. fischeri.

\subsection{Bioaumentação no reator biológico sem pré tratamento do efluente industrial (Teste B)}

\subsubsection{Resultados dos ensaios físico-químicos}

Nas tabelas 23 a 28, a seguir, apresentam-se os dados dos ensaios de $\mathrm{pH}$, Demanda Química de Oxigênio, Sólidos em Suspensão Totais, Sólidos Sedimentáveis, Nitrogênio Amoniacal, Surfactantes e Fenol, nas amostras do reator biológico da E.T.E. simulada, antes e depois da introdução dos consórcios microbianos juntamente com o efluente industrial não pré tratado.

Tabela 23 - Resultados de pH do biorreator que simulou o tanque de aeração da E.T.E. ao receber efluente industrial sem pré tratamento, antes e depois da introdução dos consórcios microbianos.

\begin{tabular}{lccc}
\hline \multicolumn{1}{c}{ AMOSTRA } & pH AFL. & pH EFL. & Variação (\%) \\
\hline CONTROLE & $7,0 \pm 0$ & $7,0 \pm 0,4$ & 0 \\
BEN & 7,0 & 6,9 & -1 \\
CLF & 7,0 & 7,0 & 0 \\
DCE & 7,0 & 8,1 & 14 \\
PCF & 7,0 & 7,9 & 11 \\
TCE & 7,0 & 7,2 & 3 \\
TOL & 7,0 & 6,4 & -9 \\
XIL & 7,0 & 7,0 & 0 \\
\hline
\end{tabular}


Controle $=$ sem bioaumentação

BEN, CLF, DCE, PCF, TCE, TOL e XIL = bioaumentação com adição de diferentes consórcios microbianos.

Tabela 24 - Resultados de DQO do biorreator que simulou o tanque de aeração da E.T.E. ao receber efluente industrial sem pré tratamento, antes e depois da introdução dos consórcios microbianos.

\begin{tabular}{lccc}
\hline AMOSTRA & $\begin{array}{c}\text { DQO AFL. } \\
\left(\mathbf{m g O}_{\mathbf{2}} / \mathbf{L}\right)\end{array}$ & $\begin{array}{c}\text { DQO EFL. } \\
\left(\mathbf{m g O}_{\mathbf{2}} / \mathbf{L}\right)\end{array}$ & $\begin{array}{c}\text { Variação } \\
(\%)\end{array}$ \\
\hline CONTROLE & $623,7 \pm 42$ & $137,4 \pm 38$ & 78 \\
\hline BEN & 623,7 & 204,0 & 67 \\
CLF & 623,7 & 128,2 & 79 \\
DCE & 623,7 & 174,9 & 72 \\
PCF & 623,7 & 151,9 & 76 \\
TCE & 623,7 & 131,6 & 79 \\
TOL & 623,7 & 133,7 & 79 \\
XIL & 623,7 & 139,2 & 78 \\
\hline
\end{tabular}

Controle $=$ sem bioaumentação

BEN, CLF, DCE, PCF, TCE, TOL e XIL = bioaumentação com adição de diferentes consórcios microbianos.

Tabela 25 - Resultados de SS do biorreator que simulou o tanque de aeração da E.T.E. ao receber efluente industrial sem pré tratamento, antes e depois da introdução dos consórcios microbianos.

\begin{tabular}{lccc}
\hline \multicolumn{1}{c}{ AMOSTRA } & $\begin{array}{c}\text { SS AFL. } \\
(\mathbf{m L S S} / \mathbf{L})\end{array}$ & $\begin{array}{c}\text { SS EFL. } \\
(\mathbf{m L S S} / \mathbf{L})\end{array}$ & $\begin{array}{c}\text { Variação } \\
(\%)\end{array}$ \\
\hline CONTROLE & $8,5 \pm 0,7$ & $<0,1$ & 99,9 \\
BEN & 8,5 & $<0,1$ & 99,9 \\
CLF & 8,5 & $<0,1$ & 99,9 \\
DCE & 8,5 & 2,0 & 76,0 \\
PCF & 8,5 & $<0,1$ & 99,9 \\
TCE & 8,5 & $<0,1$ & 99,9 \\
TOL & 8,5 & $<0,1$ & 99,9 \\
XIL & 8,5 & $<0,1$ & 99,9 \\
\hline
\end{tabular}

Controle $=$ sem bioaumentação

BEN, CLF, DCE, PCF, TCE, TOL e XIL = bioaumentação com adição de diferentes consórcios microbianos.

Tabela 26 - Resultados de nitrogênio amoniacal do biorreator que simulou o tanque de aeração da E.T.E. ao receber efluente industrial sem pré tratamento, antes e depois da introdução dos consórcios microbianos.

\begin{tabular}{lccc}
\hline AMOSTRA & $\begin{array}{c}\text { Amônia AFL. } \\
\left(\mathbf{m g N}_{\mathbf{N}} \mathbf{N H}_{\mathbf{3}} / \mathbf{L}\right)\end{array}$ & $\begin{array}{c}\text { Amônia EFL. } \\
\left(\mathbf{m g N}_{\mathbf{N}} \mathbf{N H}_{3} / \mathbf{L}\right)\end{array}$ & $\begin{array}{c}\text { Variação } \\
(\%)\end{array}$ \\
\hline CONTROLE & $65,2 \pm 20$ & $31,3 \pm 13$ & 52 \\
\hline BEN & 65,2 & 22,5 & 65 \\
CLF & 65,2 & 21,4 & 67 \\
DCE & 65,2 & 38,1 & 42 \\
PCF & 65,2 & 20,2 & 69 \\
TCE & 65,2 & 19,7 & 70 \\
TOL & 65,2 & 21,4 & 67 \\
XIL & 65,2 & 22,0 & 66 \\
\hline
\end{tabular}

Controle $=$ sem bioaumentação

BEN, CLF, DCE, PCF, TCE, TOL e XIL = bioaumentação com adição de diferentes consórcios microbianos. 
Tabela 27 - Resultados de surfactantes do biorreator que simulou o tanque de aeração da E.T.E. ao receber efluente industrial sem pré tratamento, antes e depois da introdução dos consórcios microbianos.

\begin{tabular}{lccc}
\hline \multicolumn{1}{c}{ AMOSTRA } & $\begin{array}{c}\text { ATA AFL. } \\
\text { (mgLAS/L) }\end{array}$ & $\begin{array}{c}\text { ATA EFL. } \\
\text { (mgLAS/L) }\end{array}$ & $\begin{array}{c}\text { Variação } \\
(\%)\end{array}$ \\
\hline CONTROLE & $3,1 \pm 1$ & $0,6 \pm 0,02$ & 82 \\
BEN & 3,1 & 0,1 & 97 \\
CLF & 3,1 & 0,1 & 97 \\
DCE & 3,1 & 0,5 & 84 \\
PCF & 3,1 & 0,1 & 97 \\
TCE & 3,1 & 0,1 & 97 \\
TOL & 3,1 & 0,2 & 94 \\
XIL & 3,1 & 0,1 & 97 \\
\hline
\end{tabular}

Controle $=$ sem bioaumentação

BEN, CLF, DCE, PCF, TCE, TOL e XIL = bioaumentação com adição de diferentes consórcios microbianos.

Tabela 28 - Resultados de fenol do biorreator que simulou o tanque de aeração da E.T.E. ao receber efluente industrial sem pré tratamento, antes e depois da introdução dos consórcios microbianos.

\begin{tabular}{lccc}
\hline \multicolumn{1}{c}{ AMOSTRA } & $\begin{array}{c}\text { FENOL AFL. } \\
\left(\mathrm{mgC}_{5} \mathrm{H}_{6} \mathrm{OH} / \mathrm{L}\right)\end{array}$ & $\begin{array}{c}\text { FENOL EFL. } \\
\left(\mathrm{mgC}_{5} \mathrm{H}_{6} \mathrm{OH} / \mathrm{L}\right)\end{array}$ & $\begin{array}{c}\text { Variação } \\
(\%)\end{array}$ \\
\hline CONTROLE & $0,9 \pm 0,2$ & $<0,1605$ & 99,9 \\
BEN & 0,9 & $<0,1605$ & 99,9 \\
CLF & 0,9 & $<0,1605$ & 99,9 \\
DCE & 0,9 & $<0,1605$ & 99,9 \\
PCF & 0,9 & $<0,1605$ & 99,9 \\
TCE & 0,9 & $<0,1605$ & 99,9 \\
TOL & 0,9 & $<0,1605$ & 99,9 \\
XIL & 0,9 & $<0,1605$ & 99,9 \\
\hline
\end{tabular}

Controle $=$ sem bioaumentação

BEN, CLF, DCE, PCF, TCE, TOL e XIL = bioaumentação com adição de diferentes consórcios microbianos.

Ao se comparar os resultados dos parâmetros físico-químicos dos reatores dos testes $A$ e $B$, verifica-se que, na maioria dos parâmetros, os valores iniciais detectados no teste B (afluente da E.T.E.) são, em média, 90\% inferiores aos observados no teste $A$ (efluente industrial), para os parâmetros DQO, SS, nitrogênio amoniacal e fenol. O efluente industrial possui cargas muito mais elevadas desses compostos, portanto, esse resultado já era esperado, bem como as eficiências de remoção registradas, uma vez que neste teste reproduziram-se as mesmas condições operacionais dos tanques de aeração da E.T.E. O tempo de contato da microbiota (10 horas) também foi inferior ao do teste $A$, quando os microrganismos permaneceram no reator por 36 horas.

No teste $A$, tanto no biorretor controle, quantos nos demais verificou-se alcalinização do meio, exceto no reator TOL. O meio tornou-se, em média, 12\% mais 
alcalino. No teste $\mathrm{B}$, a alcalinização foi menor, de apenas $2 \%$ em média, inclusive os reatores BEN e TOL tornaram-se 1 e 9\% mais ácidos, respectivamente, e nos reatores CLF e XIL não houve variação de pH. Esse fenômeno pode estar associado aos processos desencadeados pelas bactérias nitrificantes, uma vez que, conforme citado por Ferreira (2000), a nitrificação acidifica o meio, devido à liberação de íons $\mathrm{H}^{+}$durante determinadas etapas do processo. $\mathrm{E}$ a presença das bactérias nitrificantes obviamente é mais efetiva no reator biológico da E.T.E., que foi a base de alimentação dos reatores do teste $B$. As remoções de DQO, que no teste $A$ foram, em média, inferiores nos reatores bioaumentados, no teste B foram praticamente similares, dentro do desvio padrão do valor dos reatores controle. Apenas no reator BEN foi registrada menor eficiência. A variação de $S S$ no teste $B$ também foi superior à do teste $A$, o que também já era esperado. As remoções de nitrogênio amoniacal, surfactantes e fenol também mantiveram as mesmas correlações entre os reatores bioaumentados e os controles, em ambos os testes.

\subsubsection{Resultados dos ensaios de ecotoxicidade aguda}

Nas tabelas 29 a 32, a seguir, apresentam-se os resultados dos ensaios ecotoxicológicos realizados com os microrganismos Daphnia similis e Vibrio fischeri, nas amostras do reator biológico da E.T.E. simulada, antes e depois da introdução dos consórcios microbianos juntamente com o efluente industrial não pré tratado.

Tabela 29 - resultados dos ensaios de toxicidade para $D$. similis, expressos em Unidades Tóxicas, do efluente industrial, afluente bruto e efluente final dos reatores em batelada que simularam o tanque de aeração da ETE, bioaumentados com linhagens microbianas puras, após recebimento de efluente industrial sem pré tratamento.

\begin{tabular}{cc|ccc}
\hline & & \multicolumn{2}{c}{ Toxicidade para D. similis (U.T.) } \\
Linhagem & $\begin{array}{c}\text { Efluente } \\
\text { Industrial }\end{array}$ & $\begin{array}{c}\text { E.T.E. } \\
\text { Afluente }\end{array}$ & $\begin{array}{c}\text { E.T.E. } \\
\text { Efluente }\end{array}$ & $\begin{array}{c}\text { Variação } \\
(\%)\end{array}$ \\
\hline CONTROLE & $40,0 \pm 17$ & $37,0 \pm 3$ & $\mathbf{1 2 , 7 \pm \mathbf { 1 }}$ & $-66 \%$ \\
\hline BEN-01 & & 37,0 & $\mathbf{2 0 , 0}$ & $-46 \%$ \\
BEN-06 & 37,0 & $\mathbf{1 3 , 1}$ & $-65 \%$ \\
BEN-07 & 37,0 & $\mathbf{1 3 , 7}$ & $-63 \%$ \\
CLF-01 & 37,0 & $\mathbf{1 4 , 5}$ & $-61 \%$ \\
CLF-02 & 37,0 & $\mathbf{1 9 , 7}$ & $-47 \%$ \\
CLF-08 & 37,0 & $\mathbf{1 7 , 1}$ & $-54 \%$ \\
DCE-01 & 37,0 & $\mathbf{2 1 , 7}$ & $-41 \%$ \\
\hline
\end{tabular}




\begin{tabular}{cc|ccc}
\hline & $\begin{array}{c}\text { Toxicidade para D. similis (U.T.) } \\
\text { Efluente } \\
\text { Linhagem }\end{array}$ & $\begin{array}{c}\text { E.T.E. } \\
\text { Afluente }\end{array}$ & $\begin{array}{c}\text { E.T.E. } \\
\text { Efluente }\end{array}$ & $\begin{array}{c}\text { Variação } \\
(\%)\end{array}$ \\
\hline DCE-06 & 37,0 & $\mathbf{2 2 , 7}$ & $-39 \%$ \\
DCE-10 & 37,0 & $\mathbf{1 3 , 5}$ & $-64 \%$ \\
PCF-02 & 37,0 & $\mathbf{1 5 , 6}$ & $-58 \%$ \\
PCF-03 & 37,0 & $\mathbf{1 6 , 4}$ & $-56 \%$ \\
PCF-06 & 37,0 & $\mathbf{1 9 , 3}$ & $-48 \%$ \\
TCE-02 & 37,0 & $\mathbf{1 2 , 3}$ & $-67 \%$ \\
TCE-05 & 37,0 & $\mathbf{1 5 , 2}$ & $-59 \%$ \\
TCE-08 & 37,0 & $\mathbf{1 6 , 7}$ & $-55 \%$ \\
TOL-03 & 37,0 & $\mathbf{1 9 , 2}$ & $-48 \%$ \\
TOL-06 & 37,0 & $\mathbf{1 5 , 1}$ & $-59 \%$ \\
TOL-07 & 37,0 & $\mathbf{1 2 , 9}$ & $-65 \%$ \\
XIL-06 & 37,0 & $\mathbf{1 6 , 5}$ & $-55 \%$ \\
XIL-08 & 37,0 & $\mathbf{1 4 , 0}$ & $-62 \%$ \\
XIL-09 & $\mathbf{3 7 , 0}$ & $\mathbf{1 0 , 1}$ & $-\mathbf{7 3 \%}$ \\
\hline
\end{tabular}

Tabela 30 - resultados dos ensaios de toxicidade para $V$. fischeri, expressos em Unidades Tóxicas, do efluente industrial, afluente bruto e efluente final dos reatores em batelada que simularam o tanque de aeração da ETE, bioaumentados com linhagens microbianas puras, após recebimento de efluente industrial sem pré tratamento.

\begin{tabular}{cc|ccc}
\hline & & \multicolumn{3}{c}{ Toxicidade para V. fischeri (U.T.) } \\
& $\begin{array}{c}\text { Efluente } \\
\text { Linhagem }\end{array}$ & $\begin{array}{c}\text { E.T.E. } \\
\text { Industrial }\end{array}$ & $\begin{array}{c}\text { E.T.E. } \\
\text { Efluente }\end{array}$ & $\begin{array}{c}\text { Variação } \\
(\%)\end{array}$ \\
\hline CONTROLE & $111,1 \pm 26$ & $40,8 \pm 8$ & $\mathbf{1 9 , 2} \mathbf{2}$ & $-53 \%$ \\
\hline BEN-01 & & 40,8 & $\mathbf{3 4 , 5}$ & $-15 \%$ \\
BEN-06 & 40,8 & $\mathbf{1 3 , 5}$ & $-67 \%$ \\
BEN-07 & 40,8 & $\mathbf{1 5 , 2}$ & $-63 \%$ \\
CLF-01 & 40,8 & $\mathbf{1 4 , 5}$ & $-64 \%$ \\
CLF-02 & 40,8 & $\mathbf{2 1 , 0}$ & $-49 \%$ \\
CLF-08 & 40,8 & $\mathbf{1 8 , 1}$ & $-56 \%$ \\
DCE-01 & 40,8 & $\mathbf{1 9 , 5}$ & $-52 \%$ \\
DCE-06 & 40,8 & $\mathbf{7 6 , 9}$ & $+47 \%$ \\
DCE-10 & 40,8 & $\mathbf{4 1 , 7}$ & $+2 \%$ \\
PCF-02 & 40,8 & $\mathbf{1 7 , 2}$ & $-58 \%$ \\
PCF-03 & 40,8 & $\mathbf{2 0 , 8}$ & $-49 \%$ \\
PCF-06 & 40,8 & $\mathbf{1 0 , 5}$ & $-\mathbf{7 4 \%}$ \\
TCE-02 & 40,8 & $\mathbf{1 4 , 1}$ & $-65 \%$ \\
TCE-05 & 40,8 & $\mathbf{1 6 , 8}$ & $-59 \%$ \\
\hline
\end{tabular}




\begin{tabular}{|c|c|c|c|c|}
\hline \multirow[b]{2}{*}{ Linhagem } & \multicolumn{4}{|c|}{ Toxicidade para $V$. fischeri (U.T.) } \\
\hline & $\begin{array}{l}\text { Efluente } \\
\text { Industrial }\end{array}$ & $\begin{array}{c}\text { E.T.E. } \\
\text { Afluente }\end{array}$ & $\begin{array}{c}\text { E.T.E. } \\
\text { Efluente }\end{array}$ & $\begin{array}{c}\text { Variação } \\
(\%)\end{array}$ \\
\hline TCE-08 & & 40,8 & 16,8 & $-59 \%$ \\
\hline TOL-03 & & 40,8 & 21,7 & $-47 \%$ \\
\hline TOL-06 & & 40,8 & 15,8 & $-61 \%$ \\
\hline TOL-07 & & 40,8 & 14,3 & $-65 \%$ \\
\hline XIL-06 & & 40,8 & 16,6 & $-59 \%$ \\
\hline XIL-08 & & 40,8 & 15,1 & $-63 \%$ \\
\hline XIL-09 & & 40,8 & 14,7 & $-64 \%$ \\
\hline
\end{tabular}

Tabela 31 - resultados dos ensaios de toxicidade para $D$. similis, expressos em Unidades Tóxicas, do efluente industrial, do afluente bruto e do efluente final dos reatores em batelada que simularam o tanque de aeração da ETE, bioaumentados com consórcios microbianos, após recebimento de efluente industrial sem pré tratamento.

\begin{tabular}{|c|c|c|c|c|}
\hline \multirow[b]{2}{*}{ Linhagem } & \multicolumn{4}{|c|}{ Toxicidade para $D$. similis (U.T.) } \\
\hline & $\begin{array}{l}\text { Efluente } \\
\text { Industrial }\end{array}$ & $\begin{array}{c}\text { E.T.E. } \\
\text { Afluente }\end{array}$ & $\begin{array}{c}\text { E.T.E. } \\
\text { Efluente }\end{array}$ & $\begin{array}{c}\text { Variação } \\
(\%)\end{array}$ \\
\hline CONTROLE & $12,8 \pm 1$ & $18,9 \pm 3$ & $11,8 \pm 1$ & $-38 \%$ \\
\hline BEN & & 18,9 & 11,1 & $-41 \%$ \\
\hline CLF & & 18,9 & 11,1 & $-41 \%$ \\
\hline DCE & & 18,9 & 19,3 & $+2 \%$ \\
\hline PCF & & 18,9 & 11,1 & $-41 \%$ \\
\hline TCE & & 18,9 & N.T. & $-100 \%$ \\
\hline TOL & & 18,9 & 11,3 & $-40 \%$ \\
\hline XIL & & 18,9 & 11,2 & $-41 \%$ \\
\hline
\end{tabular}

N.T. = Não toxico

Tabela 32 - resultados dos ensaios de toxicidade para $V$. fischeri, expressos em Unidades Tóxicas, do efluente industrial, do afluente bruto e do efluente final dos reatores em batelada que simularam o tanque de aeração da ETE, bioaumentados com consórcios microbianos, após recebimento de efluente industrial sem pré tratamento.

\begin{tabular}{cc|ccc}
\hline & & \multicolumn{3}{c}{ Toxicidade para V. fischeri (U.T.) } \\
Linhagem & $\begin{array}{c}\text { Efluente } \\
\text { Industrial }\end{array}$ & $\begin{array}{c}\text { E.T.E. } \\
\text { Afluente }\end{array}$ & $\begin{array}{c}\text { E.T.E. } \\
\text { Efluente }\end{array}$ & $\begin{array}{c}\text { Variação } \\
(\%)\end{array}$ \\
\hline CONTROLE & $43,1 \pm 4$ & $10,1 \pm 1$ & $\mathbf{1 2 , 2} \pm \mathbf{1}$ & $+17 \%$ \\
\hline BEN & & 10,1 & $\mathbf{1 1 , 5}$ & $+12 \%$ \\
CLF & & $\mathbf{1 1 , 1}$ & $+9 \%$ \\
DCE & 10,1 & $\mathbf{2 1 , 4}$ & $+53 \%$ \\
PCF & 10,1 & $\mathbf{1 1 , 2}$ & $+10 \%$ \\
TCE & 10,1 & $\mathbf{1 1 , 1}$ & $+9 \%$ \\
\hline
\end{tabular}




\begin{tabular}{ccccc}
\hline & & \multicolumn{3}{c}{ Toxicidade para V. fischeri (U.T.) } \\
Efluente & E.T.E. & E.T.E. & Variação \\
Linhagem & Andustrial & Afluente & Efluente & $(\%)$ \\
\hline TOL & 10,1 & $\mathbf{1 1 , 7}$ & $+14 \%$ \\
XIL & 10,1 & $\mathbf{1 1 , 1}$ & $+9 \%$ \\
\hline
\end{tabular}

A principal finalidade da introdução dos microrganismos isolados no presente trabalho, foi a redução da toxicidade aguda a $D$. similis e $V$. fischeri no efluente final da estação de tratamento de esgotos, independente da adição ter sido feita diretamente no efluente industrial ou na biomassa do sistema de tratamento. Partindo desse ponto, a comparação dos valores de toxicidade aguda para $D$. similis, obtidos nos testes A e B demonstram claramente que, no geral, a introdução dos microrganismos no efluente industrial, de forma a pré tratá-lo, mostrou-se ser uma alternativa mais viável do que a introdução direta no reator biológico recebendo efluente industrial sem tratamento. Em 20 reatores que receberam efluente industrial sem pré tratamento, a média dos valores de toxicidade do efluente final para $D$. similis foi, aproximadamente, $74 \%$ superior a media dos que receberam o efluente industrial pré tratados. As exceções foram os reatores inoculados com as linhagens DCE-06 e DCE-10. Para V. fischeri, esse valor foi de 78\%, e não foi observada nenhuma exceção.

Provavelmente, um dos principais fatores que exerceram influência sobre esses resultados é o tempo de contato das células inoculadas com o esgoto, além do fato dos meios possuírem diferenças significativas. No teste $A$, os microrganismos foram inoculados no efluente industrial, e no teste $B$, na biomassa da E.T.E. juntamente com o efluente industrial na proporção de $7 \%$ (v/v) e esgoto afluente sem nenhuma contribuição do efluente da indústria química. No entanto, a E.T.E. recebe efluentes de inúmeras outras indústrias e estabelecimentos comerciais, de segmentos diversos. Portanto, torna-se difícil predizer as reações, os efeitos sinérgicos e as interações às quais os microrganismos se submetem ao serem inoculados nesse meio tão complexo. Além disso, talvez o tempo de contato 10 horas - não tenha sido suficiente para que os microrganismos pudessem desencadear todos os processos relacionados à remoção de toxicidade.

Nos tratamentos feitos com os consórcios, observaram-se alguns resultados inesperados. A variação da toxicidade para os dois microrganismos testados seguiu 
direções opostas. Enquanto a variação da toxicidade para $D$. similis foi, na média, negativa, ou seja, após o tratamento o meio tornou-se menos tóxico, - com exceção do reator inoculado com o consórcio DCE, que sofreu aumento de $2 \%$ - em todos os reatores houve aumento na toxicidade para $V$. fischeri, inclusive nos três reatores controle. Na literatura não foi encontrado nenhum estudo com essa divergência de dados em avaliações ecotoxicológicas nas quais foi utilizado mais de um organismo. Nesse caso, caberia um estudo mais detalhado para se apurar as razões desse fenômeno.

Ao compararem-se os resultados dos valores de toxicidade dos efluentes finais do teste $B$ em relação ao teste $A$, fica evidente a importância do pré tratamento do efluente industrial antes de seu recebimento na estação de tratamento. Enquanto no teste $A$ em quatro biorreatores a toxicidade para $D$. similis foi reduzida a zero, o mesmo ocorreu em apenas um reator no teste $B$. Além disso, os valores de toxicidade do efluente final dos demais reatores é sempre superior no teste $B$. A correlação se manteve nos resultados de toxicidade aguda para $V$. fischeri.

\subsection{Caracterização dos isolados}

\subsubsection{Caracterização fenotípica}

A Tabela 33, a seguir, apresenta os dados da caracterização fenotípica realizada nas 21 linhagens isoladas e selecionadas para os testes de bioaumentação.

Tabela 33 - Características fenotípicas das 21 linhagens microbianas isoladas e selecionadas para os testes de bioaumentação.

\begin{tabular}{lcccc}
\hline Linhagem & Coloração colônia & Oxidase & Catalase & Gram \\
\hline E. colis17-1 & & - (controle) & & \\
\hline BEN-01 & Vermelho & + & + & - \\
BEN-06 & Bege & + & + & - \\
BEN-07 & Amarelo & - & + & - \\
CLF-01 & Bege & - & - & - \\
CLF-02 & Ocre & + & + & - \\
CLF-08 & Amarelo & + & + & - \\
DCE-01 & Bege & + & + & - \\
DCE-06 & Ocre & - & + & + \\
\hline
\end{tabular}




\begin{tabular}{lcccc}
\hline Linhagem & Coloração colônia & $\begin{array}{c}\text { Oxidase } \\
\text { E. coli S17-1 }\end{array}$ & Catalase & Gram \\
\hline DCE-10 & Branco & + & + & - \\
PCF-02 & Bege & + & + & - \\
PCF-03 & Bege & + & + & - \\
PCF-06 & Bege & + & + & - \\
TCE-02 & Bege & - & + & - \\
TCE-05 & Amarelo & - & + & - \\
TCE-08 & Amarelo & - & + & - \\
TOL-03 & Bege & + & + & - \\
TOL-06 & Bege & + & + & - \\
TOL-07 & Vermelho & + & + & - \\
XIL-06 & Amarelo & - & + & - \\
XIL-08 & Bege & + & + & - \\
XIL-09 & Vermelho & + & - & - \\
\hline
\end{tabular}

De um modo geral, há uma predominância de bactérias gram-negativas (95\%) e catalase-positivas (90\%). As demais características distribuem-se de maneira mais equilibrada dentre os isolados. Como os microrganismos selecionados no presente trabalho cresceram sob forte pressão seletiva, em virtude das fontes de carbono utilizadas, não se pode considerar suas características como predominantes na microbiota de sistemas de lodos ativados, embora Cordi et al. (2003), tenham encontrado somente bactérias gram-negativas durante aclimatação de um sistema de lodos ativados a diferentes efluentes industriais, bem como Shokoohi et al. (2006), que caracterizou a diversidade da microbiota degradadora de fenol em um sistema de lodos ativados, todas gram-negativas, catalase-positivas e quase todas oxidase-positivas.

De acordo com os resultados obtidos na caracterização, para os quatro parâmetros analisados, é possível agrupar preliminarmente os microrganismos em 11 grupos, conforme a Tabela 34, a seguir: 
Tabela 34 - Classificação das linhagens microbianas isoladas de acordo com as características fenotípicas (coloração da colônia, oxidase, catalase e gram)

\begin{tabular}{|c|c|c|}
\hline Grupo & Característica & Linhagem microbiana \\
\hline $\mathrm{A}$ & colônias vermelhas, oxidase +, catalase+, gram- & BEN-01, TOL-07 \\
\hline B & colônias vermelhas, oxidase+, catalase-, gram- & XIL-09 \\
\hline C & colônias beges, oxidase+, catalase-, gram- & $\begin{array}{l}\text { BEN-06, DCE-01, PCF-02, } \\
\text { PCF-03, PCF-06, TOL-03, } \\
\text { XIL-08 }\end{array}$ \\
\hline $\mathrm{D}$ & colônias beges, oxidase-, catalase-, gram- & CLF-01 \\
\hline $\mathrm{E}$ & colônias beges, oxidase-, catalase+, gram- & TCE-02 \\
\hline $\mathrm{F}$ & colônias beges, oxidase+, catalase+, gram- & TOL-06 \\
\hline G & colônias amarelas, oxidase-, catalase+, gram- & $\begin{array}{c}\text { BEN-07, TCE-05, TCE-08, } \\
\text { XIL-06 }\end{array}$ \\
\hline $\mathrm{H}$ & colônias amarelas, oxidase+, catalase+, gram- & CLF-08 \\
\hline $\mathrm{I}$ & colônias brancas, oxidase+, catalase+, gram- & DCE-10 \\
\hline $\mathrm{J}$ & colônias ocres, oxidase+, catalase +, gram- & CLF-02 \\
\hline K & colônias ocres, oxidase-, catalase+, gram+ & DCE-06 \\
\hline
\end{tabular}

Observa-se que os dois grupos mais numerosos são: bactérias que formam colônias beges, oxidase-positivas, catalase-positivas e gram-negativas, e bactérias que formam colônias amarelas, oxidase-negativas, catalase-positivas e gramnegativas. Diversos isolados pertencem a grupos exclusivos, nos quais foi agrupado apenas um organismo.

\subsubsection{Caracterização molecular}

Algumas linhagens (BEN-06, BEN-07, CLF-01, TCE-08, XIL-06, e XIL-08) apresentaram crescimento muito baixo no caldo LB durante as 24 horas em que foram incubadas. A revelação da imagem da eletroforese confirmou a presença de bandas inexpressivas em seis linhagens. O método de extração de DNA foi repetido, mas novamente não foram observadas bandas com a mesma intensidade em todas as linhagens. Dessa forma, foram amplificados os DNAs das 15 linhagens que apresentaram bandas mais visíveis. O produto da amplificação pode ser observado na Figura 17, a seguir: 


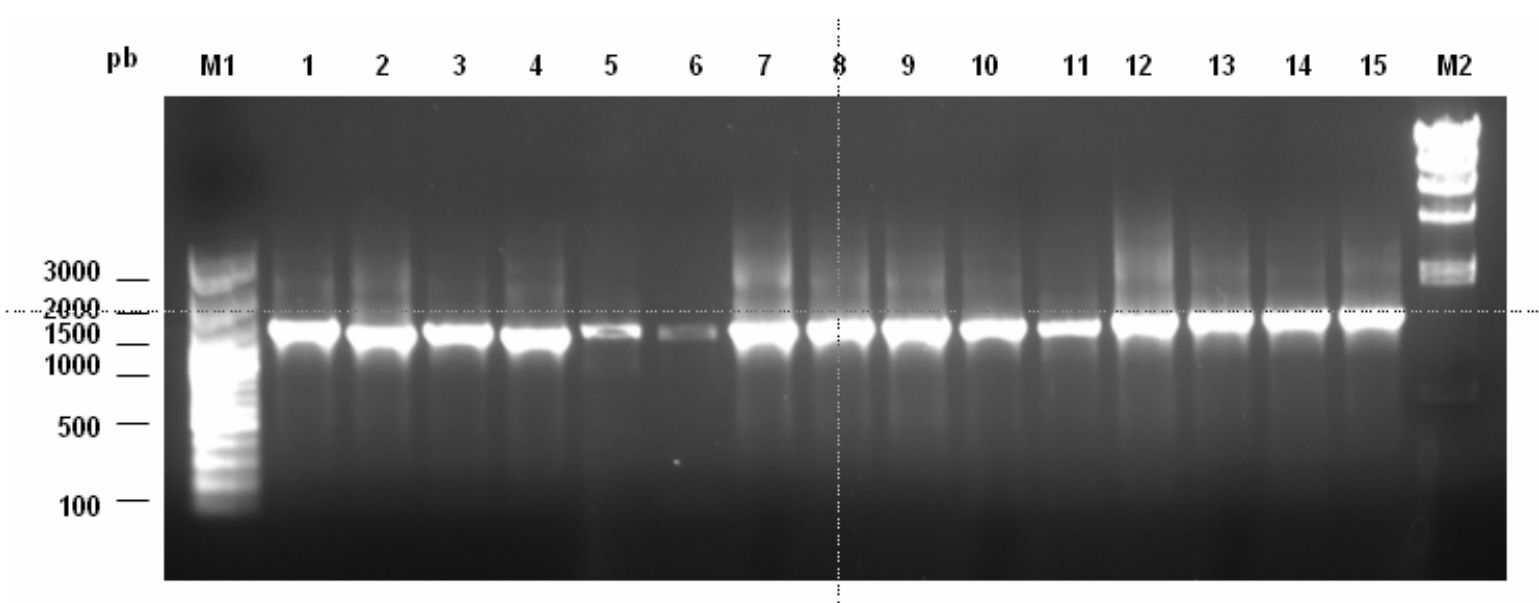

Figura 17 - Fotografia do produto do PCR do gene $16 \mathrm{~S}$ rDNA.

M1: Marcador de 100pb; M2: DNA $\lambda$ digerido com Hindlll; 1) BEN-01;2) TOL-06; 3) CLF02; 4) TOL-03; 5) DCE-01; 6) PCF-03; 7) PCF-02; 8) TCE-05; 9) XIL-09; 10) DCE-06; 11) PCF-06; 12) DCA-10; 13) CLF-08; 14) TOL-07 e 15) TCE-02.

As Figuras 18 e 19, a seguir, apresentam os resultados da digestão dos produtos de PCR com as enzimas de restrição Hhal e Haelll e agrupadas em nove grupos, de acordo com os perfis de restrição para cada enzima. A imagem da Figura 18 está exibida em contraste para facilitar a visualização das bandas.

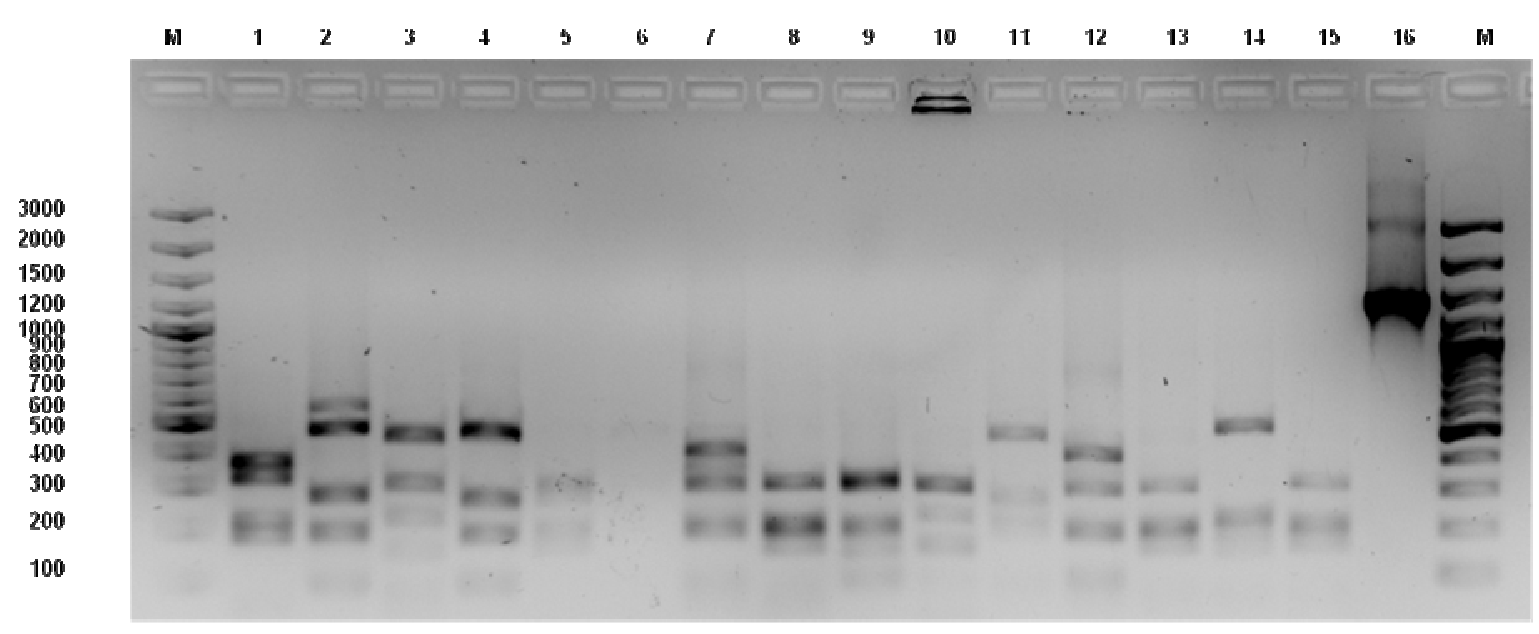

Figura 18 - Fotografia do produto da digestão do gene $16 \mathrm{~S}$ rDNA com a enzima de restrição HaellI M: Marcador de DNA de 100pb; 1) BEN-01; 2) TOL-06; 3) CLF-02; 4) TOL-03; 5) DCE01; 6) PCF-03; 7) PCF-02; 8) TCE-05; 9) XIL-09; 10) DCE-06; 11) PCF-06; 12) DCA-10; 13) CLF-08; 14) TOL-07; 15) TCE-02; 16) Produto de PCR sem digerir. $\mathrm{M}$ : contem $1 \mathrm{uL}$ de marcador $+6 \mathrm{uL}$ de loading; Amostras: 1 - 15: contém 7uL da digestão + 3uL de loading; 16: contem 4uL de produto de PCR Haell 


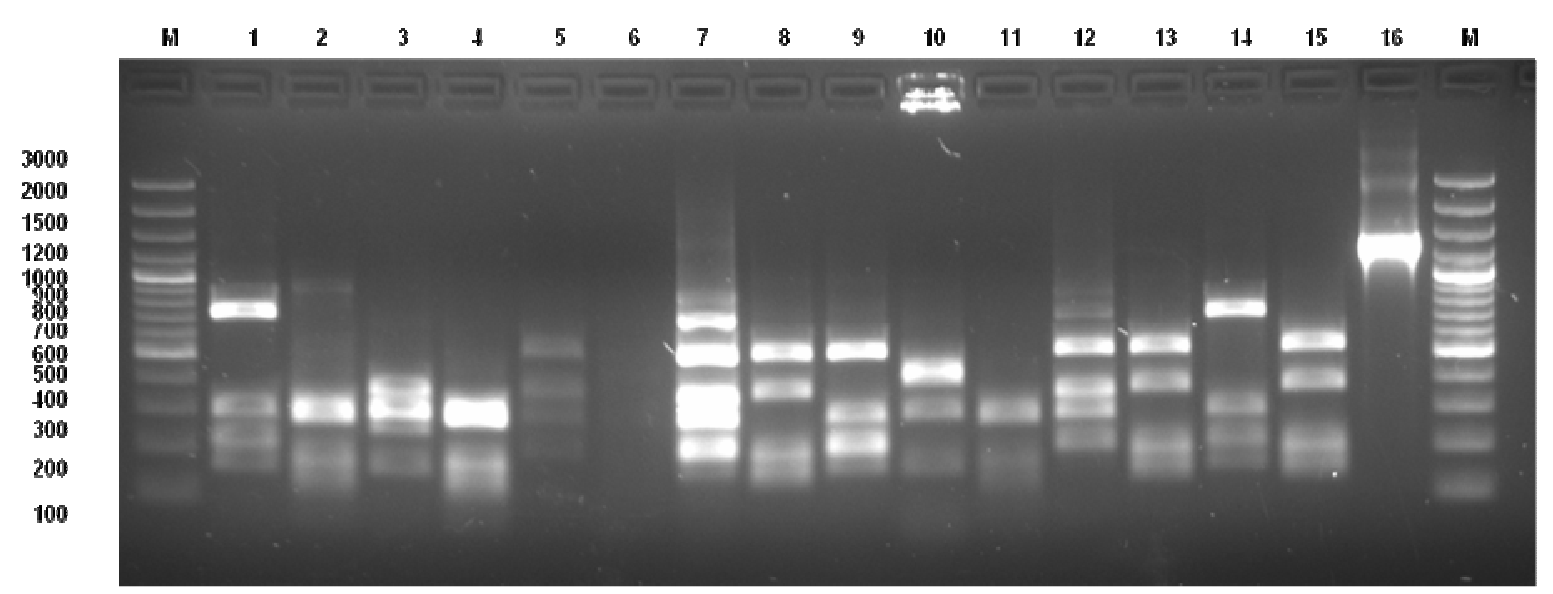

Figura 19 - Fotografia do produto da digestão do gene $16 \mathrm{~S}$ rDNA com a enzima de restrição Hhal M: Marcador de DNA de 100pb; 1) BEN-01; 2) TOL-06; 3) CLF-02; 4) TOL-03; 5) DCE01; 6) PCF-03; 7) PCF-02; 8) TCE-05; 9) XIL-09; 10) DCE-06; 11) PCF-06; 12) DCA-10; 13) CLF-08; 14) TOL-07; 15) TCE-02; 16) Produto de PCR sem digerir. $\mathrm{M}$ : contem $1 \mathrm{uL}$ de marcador +6 uL de loading;

Amostras: 1 - 15: contém 7uL da digestão + 3uL de loading; 16: contem 4uL de produto de PCR Hhal

De acordo com Jorgensen e Cluster (1989), o método ARDRA é rápido e útil na avaliação das diferenças entre grupos filogenéticos. No presente trabalho, a aplicação da técnica foi fundamental para verificar a diversidade de microrganismos presentes em uma estação de tratamento de esgotos. De acordo com os perfis de restrição das duas enzimas utilizadas para digerir o produto do PCR, os microrganismos foram classificados em diferentes grupos, da mesma forma que foi feita na caracterização fenotípica. A Figura 20 , a seguir, exibe os perfis de restrição com a classificação dos isolados em grupos, de acordo com a similaridade.

a) Haell

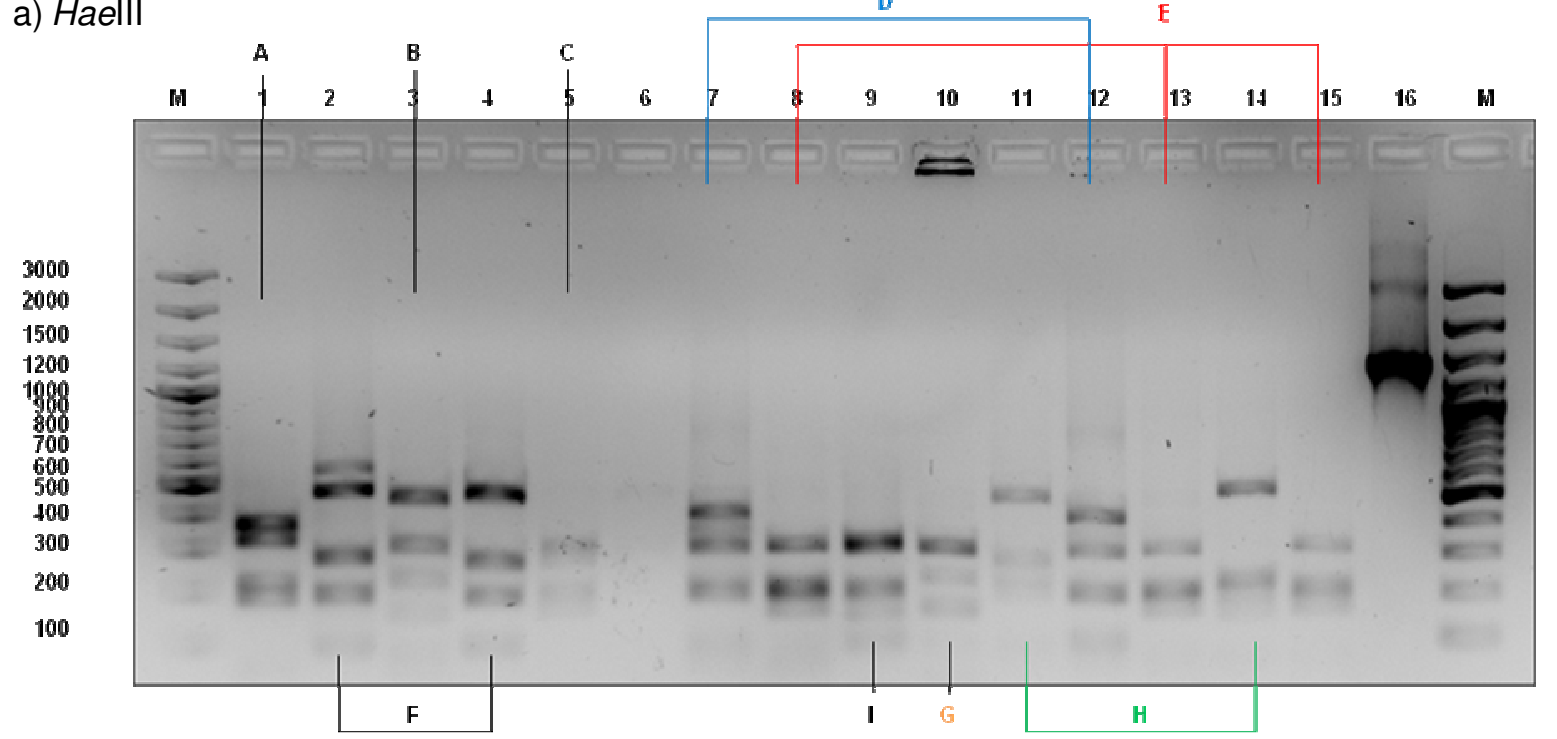




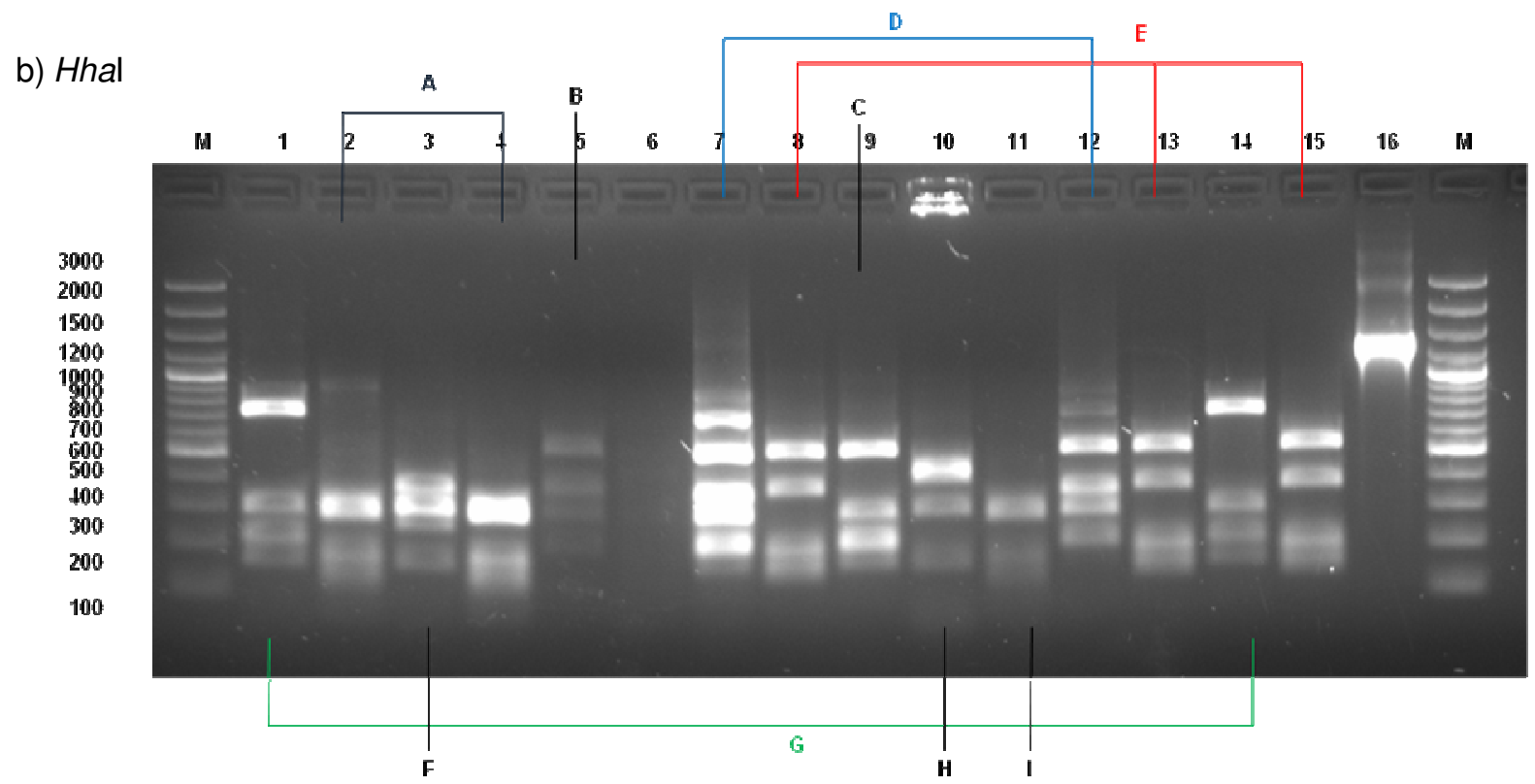

Figura 20 - Perfis de restrição e classificação dos isolados em diferentes grupos após digestão a 30 ${ }^{0} \mathrm{C}$ por $16 \mathrm{~h}$ a) com a enzima de restrição Haelli; b) com a enzima de restrição Hhal M: Marcador de DNA de 100pb; 1) BEN-01; 2) TOL-06; 3) CLF-02; 4) TOL-03; 5) DCE01; 6) PCF-03; 7) PCF-02; 8) TCE-05; 9) XIL-09; 10) DCE-06; 11) PCF-06; 12) DCA-10; 13) CLF-08; 14) TOL-07; 15) TCE-02; 16) Produto de PCR sem digerir.

De acordo com o perfil de restrição apresentado, os isolados foram classificados de acordo com a Tabela 35, a seguir:

Tabela 35 - Grupos de classificação dos isolados após digestão com as enzimas Haelll e Hhal, com o mesmo perfil de restrição.

\begin{tabular}{ccc}
\hline Grupo & Enzima Haell & Enzima Hhal \\
\hline A & BEN-01 & TOL-06, TOL-03 \\
\hline B & CLF-02 & DCE-01 \\
\hline C & DCE-01 & XIL-09 \\
\hline D & PCF-02, DCA- & PCF-02, DCA-10 \\
& 10 & TCE-05, CLF-08, \\
E & TCE-05, CLF- & TCE-02 \\
& 08, TCE-02 & CLF-02 \\
\hline F & TOL-03, TOL-06 & BEN-01, TOL-07 \\
\hline G & DCE-06 & DCE-06 \\
\hline H & PCF-06, TOL-07 & PCF-06 \\
\hline I & XIL-09
\end{tabular}


Os perfis de restrição apresentados pelas linhagens após digestão com as enzimas de restrição Haelll e Hhal, se mostraram praticamente similares entre todo o conjunto de amostras. Apenas as linhagens BEN-01, PCF-06 e TOL-07 apresentaram classificações diferentes nos dois tratamentos enzimáticos. A linhagem PCF-03 não exibiu nenhuma banda, não sendo possível, obviamente, classificá-la em nenhum grupo. Esses resultados, de certa forma, confirmam a diversidade da microbiota capaz de degradar os compostos utilizados como fonte de carbono na estação de tratamento de esgotos, o que traz boas perspectivas para o desenvolvimento futuro de novas tecnologias de tratamento biológico de efluentes não-domésticos.

Uma comparação entre os resultados do ARDRA com a caracterização fenotípica se mostra inviável, uma vez que nessa segunda, foram caracterizados todos os 21 isolados utilizados nos testes de bioaumentação, ao passo que nos ensaios de ARDRA, o número de isolados foi de 15 , em função dos problemas ocorridos durante a extração do DNA, relatados anteriormente. Entretanto, mesmo considerando-se essa questão, observaram-se algumas correlações entre os resultados dos métodos de caracterização fenotípica e genotípica. A singularidade da linhagem XIL-09 ficou evidente uma vez que as duas caracterizações demonstraram que esse organismo não possui similaridade com nenhum outro. Além desse caso, o agrupamento das linhagens CLF-02 e DCE-06 em grupos exclusivos foi observada na caracterização fenotípica e no perfil de restrição com Haelll e Hhal, respectivamente. O agrupamento das linhagens BEN-01 e TOL-07 no mesmo grupo foi observada na caracterização fenotípica e no perfil de restrição com Hhal.

Portanto, no presente trabalho, a utilização das enzimas Haelll e Hhal se mostrou eficiente na diferenciação dos isolados. Em algumas ocasiões, uma determinada enzima que é adequada para um determinado objetivo, pode não ser para outro. Barbosa (2005), utilizando a enzima Haelll não conseguiu obter um perfil de restrição que diferenciasse isolados halofílicos, para posterior utilização no tratamento de efluente de industria petroquímica, sendo necessária a utilização de outras enzimas de restrição. Entretanto, Junior et al. (2004) obtiveram êxito com a enzima Haelll para diferenciar bactérias fixadoras de nitrogênio, em comparação com outras enzimas. Em sistemas de lodos ativados, a técnica de ARDRA tem sido utilizada para caracterizar alterações nas comunidades microbianas em função do 
recebimento de cargas tóxicas, bem como em diferentes condições de oxigenação (GICH et al., 2000). Dessa forma, é uma ferramenta que pode ser uma grande aliada na avaliação das condições operacionais de uma estação de tratamento de esgotos, indicando perturbações na diversidade microbiana. 


\section{CONCLUSÕES}

Os resultados obtidos no presente trabalho possibilitaram as seguintes conclusões:

- A indústria química gera efluentes com grandes variações qualiquantitativas, carregando poluentes orgânicos que podem interferir na atividade da biomassa da estação de tratamento de esgotos que os recebe;

- Os compostos que possuem implicações com as ocorrências de toxicidade no efluente final da estação de tratamento de esgotos são: benzeno, clorofórmio, 1,2-dicloroetano, pentaclorofenol, tricloroeteno, tolueno e $p$-xileno;

- Os parâmetros físico-químicos isoladamente não são suficientes para demonstrar o efeito que o efluente final da estação de tratamento de esgotos pode causar ao corpo receptor, sendo necessária a adoção de ensaios ecotoxicológicos;

- A turbidez é um parâmetro com elevada confiabilidade e correlação com ensaios ecotoxicológicos para demonstrar eventos de inibição na estação de tratamento de esgotos. A DQO não se mostrou eficaz;

- A densidade média de microrganismos degradadores dos sete poluentes avaliados no presente trabalho, na biomassa da estação de tratamento de esgotos estudada, é de $2,87 \times 10^{7} \mathrm{UFC} / \mathrm{mL}$.

- As linhagens que apresentaram melhor crescimento nas diferentes fontes de carbono foram: BEN-01, BEN-06, BEN-07, CLF-01, CLF-02, CLF-08, DCE-01, DCE-06, DCE-10, PCF-02, PCF-03, PCF-06, TCE02, TCE-05, TCE-08, TOL-03, TOL-06, TOL-07, XIL-06, XIL-08 e XIL09 . 
- O pré-tratamento do efluente industrial antes de seu recebimento na estação de tratamento reduz a toxicidado do efluente final. A adição de linhagens diretamente no reator biológico sem pré-tratamento do efluente industrial resulta em uma menor redução de toxicidade;

- O consórcio degradador de 1,2-dicloroetano (DCE) apresentou desempenho inferior aos demais consórcios na redução da toxicidade. Duas linhagens desse consórcio (DCE-06 e DCE-10) aumentaram a toxicidade do meio em alguns tratamentos, quando inoculadas isoladamente;

- Nos testes de toxicidade realizados, o microrganismo Vibrio fischeri se mostrou mais sensível do que Daphnia similis;

- Os resultados dos testes de toxicidade com $D$. similis e $V$. fischeri demonstraram a importância de se avaliar as condições de ecotoxicidade de um efluente com pelo menos dois níveis tróficos;

- Baseado em características fenotípicas foi possível distinguir onze grupos microbianos diferentes dentre os isolados, com predomínio de bactérias gram-negativas e catalase-positivas;

- Os perfis de restrição obtidos com a utilização das enzimas de restrição Haelll e Hhal, permitiram distinguir nove grupos microbianos diferentes, dentre quinze isolados;

- As enzimas de restrição Haelll e Hhal mostraram-se ser adequadas para evidenciar a diversidade genética da microbiota degradadora dos sete poluentes utilizados na estação de tratamento de esgotos estudada. 


\section{REFERÊNCIAS BIBLIOGRÁFICAS*}

ADAMSE, A. D.; DEINEMA, M.H.; ZEHNDER, A. J. B. Studies on bacterial activities in aerobic and anaerobic waste water purification. Antoine van Leeuwenhoek International Journal of General and Molecular Microbiology, v. 50, p. 665-682, 1984.

AGATHOS, S. N.; BLACKMAN, G.; DEBOIS, V.; RENARD, M. E.; WATTIAU, P. A PCR test to identify Bacillus subtilis and closely related species and its application to the monitoring of wastewater biotreatment. Applied and Environmental Microbiology, v. 56, p. 816-819, 2001.

AGATHOS, S. N.; FANTROUSSI, S. E. Is bioaugmentation a feasible strategy for pollutant removal and site remediation? Current Opinion in Microbiology, v. 8, p. 268-275, 2005.

ALMEIDA, E.; ASSALIN, M. R.; ROSA, M. A. Tratamento de efluentes industriais por processos oxidativos na presença de ozônio. Química Nova, v. 27, n. 5, p. 818-824, 2004.

ALVAREZ, P. J. J.; HUNT, C. S. The effect of fuel alcohol on monoaromatic hydrocarbon biodegradation and natural attenuation. Revista Latinoamericana de Microbiologia, v. 44, n. 2, p. 83-104, 2002.

ALVAREZ, P. J. J.; VOGEL, T. M. Substrate interactions of benzene, toluene and para-xylene during microbial degradation by purê cultures and mixed culture aquifer slurries. Applied and Environmental Microbiology, v. 57, n. 10, p. 2981-2985, 1991.

ALVAREZ-COHEN, L.; BOULYGINA, R. S.; BRUSSEAU, G. A.; HANSON, R. S.; McCARTY, P. L. Characterization of a methane-utilizing bacterium from a bacterial consortium that rapidly degrades trichloroethylene and chloroform. Applied and Environmental Microbiology, v. 58, p. 1886-1893, 1992.

ALVES, T. L. M.; LARENTIS, A. L.; MARTINS, O. B. Cloning and expression of metacleavage enzyme (CarB) of carbazole degradation pathway from Pseudomonas stutzeri. Brazilian Archives of Biology and Technology, v. 48, p. 127-134, 2005.

AMANN, R.; LEMMER, H.; SCHLEIFER, K. H.; WAGNER, M. Probing activated sludge with proteobacteria-specific oligonucleotides: inadequacy of culturedependent methods for describing microbial community structure. Applied and Environmental Microbiology, v. 59, p. 1520-1525, 1993.

\footnotetext{
* De acordo com:

ASSOCIAÇÃO BRASILEIRA DE NORMAS TÉCNICAS. NBR 6023: Informação e documentação: referências: elaboração. Rio de Janeiro, 2002.
} 
AMANN, R.; MANZ, W.; SCHLEIFER, K. H.; WAGNER, R. In situ characterization of the microbial consortia active in two wastewater treatment plants. Water Research, v. 28, p. 1715-1723, 1994.

AMANN, R. I.; LUDWIG, W.; SCHLEIFER, K. H. Phylogenetic identification and in situ detection of individual microbial cells without cultivation. Microbiological Reviews, v. 59, p. 143-169, 1995.

AMANN, R. I.; AMMENDOLA, A.; EBERL, L.; ERHART, R.; GEISENBERGER, O.; MOLIN, S.; SCHULZE, R.; STERNBERG, C. Use of green fluorescent protein as a marker for ecological studies of activated sludge communities. FEMS Microbiology Letters, v. 149, p. 77-83, 1997.

AMANN, R.; HUBER, I.; LUDWIG, W.;SCHLEIFER, K. H.; SNAIDR, J. Phylogenetic analysis and in situ identification of bacteria in activated sludge. Applied and Enviromental Microbiology, v. 63, n. 7, p. 2884-2896, 1997.

AMERICAN PUBLIC HEATH ASSOCIATION; AMERICAN WATER WORKS ASSOCIATION; WATER ENVIRONMENTAL FEDERATION. Standard methods for the examination of water and wastewater. Washington, 1998.

APIKYAN, L. G.; DIRILGEN, N.; INCE, N. H.; TEZCANLI, G.; ÜSTÜN, B. Assessment of toxic interactions of heavy metals in binary mixtures: a statistical approach. Archives of Environmental Contamination and Toxicology, v. 36, n. 4, p. 365-372, 1999.

ARAUJO, R. P.; BERTOletTI, E.; GHERARDI-GOLDSTEIN, E.; ZAGATTO, P. A. Procedimentos para utilização de testes de toxicidade no controle de efluentes líquidos. São Paulo: Cia. de Tecnologia de Saneamento Ambiental - CETESB, 1990.

ARVIN, E.; JENSEN, B. K.; GUNDERSEN, A. T. Substrate interactions during aerobic biodegradation of benzene. Applied and Environmental Microbiology, v. 55, p. 3221-3225, 1989.

ARCIERO, D.; VANNELLI, T.; LOGAN, M.; HOOPER, A. B. Degradation of trichloroethylene by the ammonia-oxidizing bacterium Nitrosomonas europaea. Biochemical and Biophysical Research Communications, v. 159, n. 2, p. 640643, 1989.

ARCIERO, D. M.; HOOPER, A. B.; VANELLI, T.M. Degradation of halogenated aliphatic compounds by the ammonia-oxidizing bacterium Nitrosomonas europaea. Applied and Environmental Microbiology, v. 56, p. 1169-1171, 1990.

ARIMA, G. A.; CYBIS, L. F.; PICKBRENER, K. Inibição de processo aeróbio por sulfetos. In: CONGRESSO LATINO-AMERICANO DE ENGENHARIA SANITÁRIA E AMBIENTAL, 28., 2002, Cancún. Anais... Cancun: Associação Latino-Americana de Engenharia Sanitária e Ambiental, 2002. 
ASSOCIAÇÃO BRASILEIRA DE NORMAS TÉCNICAS. NBR 12.713: Ecotoxicologia aquática - Toxicidade aguda - Método de ensaio com Daphnia spp. (Crustacea, Cladocera). Rio de Janeiro, 2004.

ASSOCIAÇÃO BRASILEIRA DE NORMAS TÉCNICAS. NBR 15.411-3: Ecotoxicologia aquática - Determinação do efeito inibitório de amostras de água sobre a emissão de luz de Vibrio fischeri - Parte 3: Método utilizando bactérias liofilizadas. Rio de Janeiro, 2006.

AUTHEUNISSE, J.; KOENE, J. I. A. Alteration of the aerobic and facultative anaerobic bacterial flora of the $A / B$ purification process caused by limited oxygen supply. Water Research, v. 21, n. 1, p. 129-131, 1987.

AYUB, M. A. Z.; ORTOLAN, M. G. S. Cytotoxicity and genotoxicity of untreated hospital effluents. Brazilian Archives of Biology and Technology, v. 50, n. 4, p. 637-643, 2007.

BAEZ, M. C. D.; GRANADOS, Y. P.; RONCO, A. Ensayos toxicológicos y métodos de evaluación de calidad de águas - estandarización, intercalibración, resultados y aplicaciones. Ottawa: Centro Internacional de Investigaciones para El Dessarrollo, 2004.

BAILEY, M.; HANSEN, L. H.; KROER, N.; SORENSEN, S. J.; WUERTZ, S. Studying plasmid horizontal transfer in situ: a critical review. Nature, v. 3, p. 700-710, 2005.

BALTZIS, B. C.; LEWANDOWSKI, G. A.; WANG, K. W. Kinetics of phenol biodegradation in the presence of glucose. Biotechnology and Bioengineering, $v$. $51, \mathrm{n} 1, \mathrm{p} .87-94,2000$.

BARBOSA, D. C. Identificação de bactérias halofílicas/halotolerantes com potencial uso no tratamento de água de produção. $116 \mathrm{f}$. Dissertação (Mestrado em Engenharia Quimica) - Escola de Quimica, Universidade Federal do Rio de Janeiro, Rio de Janeiro, 2005.

BARROS, M. J.; NOZAKI, J. Redução de poluentes de efluentes das indústrias de papel e celulose pela floculação/coagulação e degradação fotoquímica. Química Nova, v. 25, n. 5, p. 736-740, 2002.

BAEYENS, J.; CREEMERS, C.; JULIASTUTI, S. R. Inhibition of nitrification by heavy metals and organic compounds: the ISO 9509 test. Environmental Engineering Science, v. 20, n. 2, 2003.

BELLO, O. O.; OJUMU, T. V.; SOLONOM, B. O.; SONIBARE, J. A. Evaluation of microbial systems for bioremediation of petroleum refinery effluents in Nigeria. African Journal of Biotechnology, v. 4, p. 31-35, 2005.

BENEDICT, R. G., CARLSON, D. A. Aerobic heterotrophic bacteria in activated sludge. Water Research, v. 5, p. 1023-1030, 1971 
BERG, U. T.; FRIMER-LARSEN, H.; INGERSLEV, F.; NYHOLM, N.; PEDERSEN, J. $P$. Estimation of kinet rate constants for biodegradation of chemicals in activated sludge wastewater treatment plants using short term batch experiments and $\mu \mathrm{g} / \mathrm{L}$ range spiked concentrations. Chemosphere, v. 33, n. 5, p. 851-864, 1996.

BERTAZZOLI, R.; PELEGRINI, R. Descoloração e degradação de poluentes orgânicos em soluções aquosas através do processo fotoeletroquímico. Química Nova, v. 25, n. 3, p. 447-482, 2002.

BILA, D. M.; DEZOTTI, M. Fármacos no meio ambiente. Química Nova, v. 26, n. 4, p. 523-530, 2003.

BOILLOT, C.; PANOUILLÈRES, M.; PERRODIN, Y. Study of the combined effects of a peracetic acid-based disinfectant and surfactants contained in hospital effluents on Daphnia magna. Ecotoxicology, v. 16, n. 3, p. 327-340, 2007.

BOON, N.; GORIS, J.; de VOS, P.; TOP, E. M.; VERSTRAETE, W. Bioaugmentation of Activated Sludge by an Indigenous 3-Chloroaniline-Degrading Comamonas testosteroni strain, 12gfp. Applied and Environmental Microbiology, v. 66, n. 7, p. 2906-2913, 2000.

BOON, N.; SICILIANO, S. D.; TOP, E. M.; VERSTRAETE, W. Bioaugmentation as a tool to protect the structure and function of an activated sludge microbia community against a 3-chloroaniline shock load. Applied and environmental Microbiology, v. 69, n. 3, p. 1511-1520, 2003.

BOTTA, C. M. R.; COSTA, C. R.; ESPINDOLA, L. G.; OLIVI, P. A toxicidade em ambientes aquáticos: discussão e métodos de avaliação. Química Nova, v. 31, n. 7, p. 1820-1830, 2008.

BOUCHEZ, T.; DABERT, P.; DELGENÈS, P.; DORÉ, J.; JURETSCHKO, S.; MOLETTA, R.; WAGNER, M. Ecological study of a bioaugmentation failure. Environmental Microbiology, v. 2, n. 2, p. 179-190, 2000.

BOUCHEZ, T.; DABERT, P.; DELGENES, J. P.; MOLLETA, R.; PATUREAU, D.; WAGNER, M. Successful and unsuccessful bioaugmentation experiments monitored by fluorescent in situ hybridization. Water Science and Technology, v. 41, n. 12, p. 61-68, 2000.

BOUWER, E. J.; McCARTY, P. L.; RITTMANN, B. E. Anaerobic degradation of halogenated 1- and 2-carbon organic compounds. Environmental Science and Technlogy, v. 15, n. 5, p. 596-599, 1981.

BOUWER, E. J.; McCARTY, P. L. Modeling of trace organics biotransformation in the subsurface. Ground Water, v. 22, p. 433-440, 1984.

BOYD, S. A.; MIKESELL, M. D. Dechlorination of chloroform by Methanosarcina strains. Applied and Environmental Microbiology, v. 56, p. 1198-1201, 1990. 
BRACKLOW, U.; DREWS, A.; KRAUME, M.; LIWARSKA-BIZUKOJC, E.; SCHEUMANN, R. Effect of anionic and nonionic surfactants on the kinetics of the aerobic heterotrophic biodegradation of organic matter in industrial wastewater. Water Research, v. 42, n. 4, p. 923-930, 2008.

BRAILE, P. M.; CAVALCANTI, J. E. W. A. Manual de tratamento de águas residuárias industriais. São Paulo: CETESB, 1993.

BURNS, R. G.; FIALHO, A. M.; SA-CORREIA, I.; SILVA, E.; SHAW, R. G. Combined bioaugmentation and biostimulation to clean up soil contaminated with high concentrations of atrazine. Environmental Science and Technology, v. 38, p. 632637,2004

CASSIDY, M. B.; LEE, H.; LEUNG, K. T.; LOHMEIER-VOGEL, E. M.; SHAW, K. W.; TREVORS, J. T.; VOGEL, H. J. Pentachlorophenol biodegradation by Pseudomonas spp. UG25 and UG30. World Journal of Microbiology and Biotechnology, v. 13, p. 305-313, 1997.

CHANG, H. L.; ALVAREZ-COHEN, L. Transformation capacities of chlorinated organics by mixed cultures enriched on methane, propane, toluene or phenol. Biotechnology and Bioengineering, v. 45, p. 440-449, 1995.

CHENG, S.; CHEN, S.; LYN, Y. Enhanced biodegradation of organic nitrogenous compounds in resin manufacturing wastewater by anoxic denitrification and oxic nitrification process. Water Science and Technology, v. 34, p. 35-41, 1996.

CLEMENT, B.; JANSSEN, R. C.; DÜ-DELEPIERRE, A. Estimation of the hazard of landfills through toxicity testing of leachates. Chemosphere, v. 35, n. 11, p. 27832796, 1997.

COMPANHIA DE SANEAMENTO BASICO DO ESTADO DE SÃO PAULO. Analises microbiológicas do lodo ativado. São Paulo: SABESP, 2002.

COMPANHIA DE SANEAMENTO BASICO DO ESTADO DE SÃO PAULO. Relatório Mensal Operacional da Estação de Tratamento de Esgotos. Suzano: SABESP, 2008.

COMPANHIA DE TECNOLOGIA DE SANEAMENTO AMBIENTAL. Norma CETESB № L5.018: Água e testes de toxicidade aguda com Daphnia similis Claus, 1876 (Cladocera, Crustácea). São Paulo, 1986.

COMPANHIA DE TECNOLOGIA DE SANEAMENTO AMBIENTAL. Norma CETESB № L1.022/029774. Utilização de produtos biotecnológicos para tratamento de efluentes líquidos, resíduos sólidos e recuperação de locais confinados: procedimento. São Paulo, 1994.

COMPANHIA DE TECNOLOGIA DE SANEAMENTO AMBIENTAL. Microbiologia de lodos ativados. São Paulo: CETESB, 2000. 
CONSELHO NACIONAL DO MEIO AMBIENTE. Resolução CONAMA n. 357/05. Disponível em <http://www.mma.gov.br/port/conama/res/res05/res35705.pdf>. Acesso em: 11 jan. 2007.

COOK, S. R.; DICKINSON, D. J. Studies on the toxicity of IPBC and other biocides to bacteria. In: ANNUAL MEETING, 35., 2004, Ljubljana.

COOK, A. M.; EGLI, C.; LEISINGER, T.; SCHOLTZ, R. Anaerobic dechlorination of tetrachloromethane and 1,2-dichloroethane to degradable products by pure cultures of Desulfobacterium sp. and Methanobacterium sp. FEMS Microbiology Letters, v. 43, p. 257-261, 1987.

COOK, A. M.; EGLI, C. S.; LEISINGER, T. Transformation of tetra- and trichloromethane to $\mathrm{CO}_{2}$ by anaerobic bacteria is a nonenzymic process. FEMS Microbiology Letters, v. 68, p. 207-212, 1990.

CORDI, L.; ALMEIDA, L.; ASSALIN, M. R.; DURAN, N.; MORAES, S. G.; SPIER, K. Impacto na microbiota do lodo ativado durante aclimatação com diferentes efluentes industriais. In: CONGRESSO NACIONAL DE FERMENTAÇOES, 16., 2003, Florianopolis. Anais... Florianópolis: 2003.

COSTA, A. J. M. P.; FERRARESI, G. N.; LEITE, J. V.; MORITA, D. M.; SOBRINHO, P. A. Avaliação da toxicidade do fenol ao tratamento biológico de águas residuárias de coquerias pelo método do "fed-batch reactor" (FBR) modificado. In: CONGRESSO BRASILEIRO DE ENGENHARIA SANITARIA E AMBIENTAL, 19., 1997, Foz do Iguaçu. Anais... Rio de Janeiro: ABES, 1997.

COSTA, F. C., CAMPOS, J. C., DEZOTI, M., FONTOURA, G. A. T., RODRIGUES, F. A. M., SANT'ANNA, G. L. J. Tratamento de efluente de uma indústria química pelo processo de lodos ativados convencional e combinado com carvão ativado. Engenharia Sanitária e Ambiental, v. 8, n. 4, p. 274-284, 2003.

COSTA, M. J. C.; LEITE, V. D.; LOPES, W. S.; SOUZA, J. T. Co-digestão anaeróbia de substâncias surfactantes, óleo e lodo de esgoto. Engenharia Sanitária e Ambiental, v. 12, n. 4, p. 433-439, 2007.

CUTOLO, S. A. Dinâmica populacional da microfauna em sistemas de tratamento de esgotos pelo processo de lodos ativados. $94 \mathrm{f}$. Dissertação (Mestrado em Saúde Pública) - Faculdade de Saúde Pública, Universidade de São Paulo, São Paulo, 1996.

DEBEST, J. H.; DODDEMA, H. J.; SALMINEN, E. Transformation of carbon tetrachloride under sulfate reducing conditions. Biodegradation, v. 8, n. 6, p. 429436, 1998.

DELLAMATRICE, P. M. Biodegradação e toxicidade de corantes têxteis e efluentes da Estação de Tratamento de Águas Residuárias de Americana, SP. 136 f. Tese (Doutorado em Ecologia de Agroecossistemas) - Escola Superior de Agricultura Luiz de Queiróz, Universidade de São Paulo, Piracicaba, 2005. 
DELATORRE Jr, I.; MORITA, D. M. Avaliação da eficácia dos critérios de recebimento de efluentes não-domésticos em sistemas de coleta e transporte de esgotos sanitários em São Paulo. Engenharia Sanitária e Ambiental, v. 12, n. 1, p.62-70, 2007.

DIAZ, E. Bacterial degradation of aromatic pollutants: a paradigm of metabolic versatility. International Microbiology, v. 7, p. 173-180, 2004.

DRAKIDES, C.; LAY-SON, M. New approach to optimize operational conditions for the biological treatment of a high-strength thiocyanate and ammonium waste: $\mathrm{pH}$ as a key factor. Water Research, v. 42, n. 3, p. 774-780, 2008.

EIROA, M.; KENNES, C. VEIGA, M. C. Biological treatment of industrial wastewater containing formaldehyde and formic acid. Water S.A., v. 32, n. 1, p. 115-118, 2006.

ELY, R. L.; ARP, D. J.; GUENTHER, R. B.; HYMAN, M. R.; WILLIAMSON, K. J. A cometabolic kinetics model incorporating enzyme inhibition, inactivation and recovery: II trichloroethylene degradation experiments. Biotechnology and Bioengineering, v. 46, n. 3, p. 232-245, 1995.

ENVIRONMENTAL PROTECTION AGENCY. Onsite Wastewater Treatment Systems Manual. Disponível em:

<http://www.epa.gov/nrmrl/pubs/625r00008/html/625R00008.htm>. Acesso em: 17 jun. 2008.

FARQUHAR, G. J. Leachate: production and characterization. Canadian Journal of Civil Engineering, v. 16, p. 317-325, 1989.

FATHEPURE, B. Z.; TIEDJE, J. M. Reductive dechlorination of tetrachloroethylene by a chlorobenzoate-enriched biofilm reactor. Environmental Science Technology. v. 28, p. 746-752, 1994.

FERREIRA, S. F. Cinética química e fundamentos dos processos de nitrificação e denitrificação biológica. In: CONGRESSO INTERAMERICANO DE ENGENHARIA SANITARIA E AMBIENTAL, 27., 2000, Porto Alegre. Anais... Rio de Janeiro: ABES, 2000.

FETZNER, S.; LINGENS, F. Bacterial dehalogenases: biochemistry, genetics and biotechnological applications. Microbiological Reviews, v. 58, n. 4, p. 641-685, 1994.

FONG, K. P. Y.; TAN, H. M. Isolation of a microbial consortium from activated sludge for the biological treatment of food waste. World Journal of Microbiology $\mathbf{e}$ Biotechnology, v. 16, p. 441-443, 2000.

FURUKAWA, K.; KIMURA, N. Biochemistry and genetics of PCB metabolism. Environmental Health Perspectives, v. 103, n. 5, 1995. 
GABARDO, I. T.; MARTINS, M. D. M.; VITAL, R. L.; URURAHY, A. F. P. Effect of aeration on biodegradation of petroleum waste. Revista de Microbiologia, v. 29, n. 4, 1998.

GALLI, R.; McCARTY, P. L. Biotransformation of 1,1,1-trichloroethane, trichloromethane and tetrachloromethane by a Clostridium sp. Applied and Environmental Microbiology, v. 55, p. 837-844, 1989.

GAVALA, H. N.; KOPSINIS, H.; LYBERATOS, G.; SKIADAS, I. V.; STAMATELATOU, K. Treatment of dairy wastewater using an upflow anaerobic sludge blanket reactor. Journal of Agricultural Engineerig Research, v. 73, n. 1, p. 59-63, 1999.

GENTRY, T. J.; PEPPER, I. L.; RENSING, C. New approaches for bioaugmentation as a remediation technology. Critical Reviews in Environmental Science and Technology, v. 34, p. 447-494, 2004.

GICH, F. B.; ABELLA, C. A.; AMER, E.; BALAGUER, M. D.; FIGUEIRAS, J. B.; $\mathrm{POCH}, \mathrm{M}$. Assessment of microbial community structure changes by amplified ribosomal DNA restriction analysis (ARDRA). International Microbiology, v. 3, p. 103-106, 2000.

GONZALES, J. F.; WEI-SHOU, H. Pentachlorophenol biodegradation: simple models. Environmental Technology, v. 16, n. 3, p. 287-293, 1995.

GOSSET, J. M. Anaerobic degradation of $\mathbf{C}_{1}$ and $\mathbf{C}_{2}$ chlorinated hydrocarbons. Florida: US Air Force Engineering and Services Center, 1985.

HAGE, J. C.; HARTMANS, S. Monooxygenase-mediated 1,2-dichloroethane degradation by Pseudomonas sp. strain DCA1. Applied and Environmental Microbiology, v. 65, n. 6, p. 2466-2470, 1999.

HAMER, G. Microbial consortia for multiple pollutant biodegradation. Pure e Applied Chemistry, v. 89, n. 11, p. 2343-2356, 1997.

HEUER, H.; SMALLA, K. Application of denaturing gradient gel electrophoresis and temperature gel electrophoresis for studying soil microbial communities. In: Modern Soil Microbiology. New York: Marcel Dekker Inc., 1997.

HOCEVAR, C. M.; RODRIGUES, M. T. R., Avaliação do impacto ambiental gerado por efluentes fotográficos, gráficos e radiológicos em Porto Alegre, RS, Brasil. Engenharia Sanitária e Ambiental, v. 7, n. 4, p. 139-143, 2002.

HOGENKAMP, H. P. C.; KRONE, U. E.; LAUFER, K.; THAUER, R. K. Coenzime F 430 as a possible catalyst for the reductive dehalogenation of chlorinated $\mathrm{C}_{1}$ hydrocarbons in methanogenic bacteria. Biochemistry, v. 28, p. 10061-10065, 1989.

JANG, J. Y.; BAE, H. W.; CHAE, J. C.; CHOI, K. Y.; KIM, D.; KIM, E.; ZYLSTRA, G. $\mathrm{J}$. Isolation and characterization of a Rhodococcus species strain able to grow on ortho- and para-xylene. The Journal of Microbiology, v. 43, n. 4, p. 325-330, 2005. 
JANSSEN, D. B.; OLDENHUIS, R.; VINK, R. L. J. M.; WITHOLT, B. Degradation of chlorinated aliphatic hydrocarbons by Methylosinus trichsporium OB3b expressing soluble methane monooxigenase. Applied and Environmental Microbiology, v. 55, p. 2819-2826, 1989.

JANSSEN, D. B.; PLOEG, V. D.; PRIES, F. Genetic adaptation of bacteria to halogenated aliphatic compounds. Environmental Health Perspectives, v. 103, n. 5, 1995.

JANSSEN, D. B.; DINKIA, I. J. T.; POELARENDS, G. J.; TERPSTRA, P. Bacterial degradation of xenobiotic compounds: evolution and distribuiton of novel enzyme activies. Environmental Microbiology, v. 7, n. 12, p. 1868-1882, 2005.

JORDAO, E. P. Tratamento de esgotos domésticos. Rio de Janeiro: ABES, 1995.

JORGENSEN, R. A.; CLUSTER, P. D.; Modes and temps in the evolution of nuclear ribossomal DNA: new characters for evolutionary studies and new markers for genetic and population studies. Annual Missouri Botanical Garden, v. 75, p. 12381247, 1989.

REIS JUNIOR, F. B.; REIS, V. M.; TEIXEIRA, K. R. S. Análises de restrição do DNA ribossomal amplificado (ARDRA) em estudos de diversidade intraespecífica de Azospirillum amazonense isolado de diferentes espécies de Brachiaria. Planaltina: Embrapa, 2004.

KOCAMEMI, B. A.; ÇEÇEN, F. Kinetic analysis of the inhibitory effect of trichloroethylene (TCE) on nitrification in cometabolica degradation. Biodegradation, v. 18, p. 71-81, 2007.

KOMORI, K.; OKAYASU, Y.; SATO, C.; TANAKA, H. Effects of hazardous substances on treatability of the activated sludge processes. In: IWA ASIA PACIFIC REGIONAL CONFERENCE, 2003, Bangkok. Proceedings... Bangkok: IWA, 2003.

KULPA C. F.; McFARLAND, B. L.; SCHOEDEL, B. A.; SELVARATNAM, S. Application of reverse transcriptase PCR for monitoring expression of the catabolic $d m p N$ gene in a phenol-degrading sequencing batch reactor. Applied and environmental Microbiology, v. 61, n. 11, p. 3981-3985, 1995.

LANE, D. J. 16S/23S rRNA sequencing. In: Nucleic Acid Techniques in Bacterial Systematics. New York: Wiley, 1991.

LEFEBVRE, O.; MOLETTA, R. Treatment of organic pollution in industrial saline wastewater: a literature review. Water Research, v. 40, n. 20, p. 3671-3682, 2006.

LEITE, J. V.; MORITA, D. M. Testes de toxicidade para avaliação do impacto de despejos industriais em sistemas biológicos de tratamento de esgotos. Engenharia Sanitária e Ambiental, v. 4, n. 3, p. 142-151, 1999. 
LYBERATOS, G. An integrated approach for management of agricultural industries wastewater. Nonlinear Analysis, Theory, Methods e Applications, v. 30, p. 23412351, 1997.

MADONI, P.; DAVOLI, D.; CHIERICI, E. Comparative analysis of the activated sludge microfauna in several sewage treatment works. Water Research, v. 9, n. 27, p.1485-1491, 1993.

MARAIS, G.; VAN HAANDEL, A. O comportamento do sistema de lodo ativado teoria e aplicação para projeto e operação. Campina Grande: Ed. ABES, 1999.

MASSOL-DEYA, A.A., ODELSON, D.A. HICKEY, R.F. \& TIEDJE, J.M. (1995) Bacterial community fingerprinting of amplified 16S and 16-23S ribosomal DNA gene sequences and restriction endonuclease analysis (ARDRA). In: Molecular Microbial Ecology Manual. Netherlands: Kluwer Academic Publishers, 1995.

MAYER, J. G.; MUÑOZ, A. R. N.; ORDAZ, N. R.; RAMIREZ, C. J.; ROJAS, F. J. M.; URBINA, E. C. Batch and fed-batch cultures for the treatment of whey with mixed yeast cultures. Process Biochemistry, v. 35, n. 7, p. 649-657, 2000.

MCCARTY, L. S.; RAND, G. M.; WELLS, P. G. Fundamentals of aquatic toxicology: effects, environmental fate and risk assessment. Washington, DC: Taylor \& Francis Ed., 1995.

MCGRATH R.; SINGLETON, I. Pentachlorophenol transformation in soil: a toxicological assessment. Soil Biology and Biochemistry, v. 32, p. 1311-1314, 2000.

MCTAVISH, H.; SADOWSKY, M. J.; STRONG, L. C.; WACKETT, L. P. Field-scale remediation of atrazine-contaminated soil using recombinant Escherichia coli expressing atrazine chlorohydrolase. Environmental Microbiology, v. 2, p. 91-98, 2000.

METCALF \& EDDY. Wastewater Engineering - International Edition. USA: Mc. Graw-Hill, 2003.

MELCHIOR, S. C.; PELEGRINI, R. T. Influência do ambiente químico na microbiota nos processos de tratamentos biológicos. Campinas: UNICAMP, 2005

MILEVA, A.; BESCHKOV, V.; SAPUNDZHIEV, T. S. Modeling 1,2-dichloroethane biodegradation by Klebsiella oxytoca va 8391 immobilized on granulated activated carbon. Bioprocess Biosystem Engineering, v. 31, p. 75-85, 2008.

MORAIS, J. L.; PERALTA-ZAMORA, P. G.; SIRTORI, C. Tratamento de chorume de aterro sanitário por fotocatálise heterogênea integrada a processo biológico convencional. Química Nova, v. 29, n. 1, p. 20-23, 2006. 
MORITA, D. M.; SAPIA, P. M. A. Critérios de recebimento de efluentes não domésticos em sistemas públicos de esgotos: uma análise crítica. Engenharia Sanitária e Ambiental, v. 8, n. 3, p.145-156, 2003.

MORITA, D. M.; SAPIA, P. M. A. Proposta de critérios de recebimento de efluentes não domésticos para o sistema público de esgotos na região metropolitana de São Paulo. Engenharia Sanitária e Ambiental, v. 8, n. 3, p.157-169, 2003.

MUNETA, M.; NAKAMURA, K.; NASU, M.; SHIBUYA, K.; TANI, K. Monitoring of Ralstonia eutropha KT1 in groundwater in an experimental bioaugmentation Field by in situ PCR. Applied and Environmental Microbiology, v. 68, n. 1, p. 412-416, 2002.

NAHAR, N.; ALAUDDIN, M.; QUILTY, B. Toxic effects of toluene on the growth of activated sludge bacteria. World Journal of Microbiology and Biotechnology, v. 16, p. 307-311, 2000.

NAHAR, N.; QUILTY, B. Cultural conditions for the growth of Pseudomonas and Aeromonas spp. on toluene. Journal of Scientific and Industrial Research, v. 58, p. 586-590, 1999.

NAKANO, Y.; NISHIJIMA, W.; OKADO, M.; SOTO, E. Relationship between growth rate of phenol utilizing bactéria and the toxic effects of metabolic intermediates of trichloroethylene. Water Research, v. 33, n. 4, p. 1085-1089, 1999.

PARAÍBA, L. C.; SAITO, M. L. Distribuição ambiental de poluentes orgânicos encontrados em lodos de esgoto. Pesquisa Agropecuária Brasileira, v. 40, n. 9, p. 853-860, 2005.

PARSONS, F.; DE MARCO, J.; WOOD, P. R. Transformations of tetrachloroethene and trichloroethane in microcosms and groundwater. Journal American Water Works Association, v. 76, p. 56-59, 1984.

PEREIRA, I. W.; ANDRADE, E. M. Estudo sobre compostos orgânicos voláteis na estação de tratamento de esgotos de Suzano - SP In: CONGRESSO BRASILEIRO DE ENGENHARIA SANITARIA E AMBIENTAL, 19., 1997, Rio de Janeiro. Anais... Rio de Janeiro: ABES, 1997.

RAMSAY, B. A.; BATAILLE, P.; CHAVARIE, C.; DUBE, B.; LOMALIZA, K.; RAMSAY, J. Production of poli- $\square$-hidroxibutiric-co- $\square$-hidroxivaleric acid. Applied and Environmental Microbiology, vol. 56, n. 7, p. 2093-2098, 1990.

RAND, G. M.; PETROCELLI, S. R. Fundamentals of Aquatic Toxicology. Hemisphere Publishing Corporation. 666p. 1985.

REID, I. D.; PAICE, M. G. Effects of manganese peroxidase on residual lignin of softwood kraft pulp. Applied and Environmental Microbiology, v. 64, n. 6, p. 22732274, 1998. 
REINEKE, W. Development of hybrid strains for the mineralization of chloroaromatics by patchwork assembly. Annual Reviews in Microbiology, v. 52, p. 287-331, 1998.

RIBO, J. M. Interlaboratory comparison studies of the luminescent bacteria toxicity bioassay. Environmental Toxicology and Water Quality, v. 12, n. 4, p. 283-294, 1997.

RODRIGUES, M. B.; PAIVA, T. C. B.; SILVA, F. T. Caracterização física, química e ecotoxicológica de efluente da indústria de fabricação de explosivos. Química Nova, v. 30, n. 7, p. 1623-1627, 2007.

SAMPAIO, A. O.; BOCCHIGLIERI, M. M.; OLIVEIRA, M. E. T. Avaliação de metodologia para controle do recebimento de efluentes não domésticos no sistema público de esgoto. In: 20 CONGRESSO BRASILEIRO DE ENGENHARIA SANITARIA E AMBIENTAL, 1999, São Paulo. Anais do 20 Congresso Brasileiro de Engenharia Sanitária e Ambiental, São Paulo, 1999.

SCHEUNERT, I. Transformation and degradation of pesticides in soil. In: Terrestrial Behavior of Pesticides. Springer Verlag, 1992.

SECRETARIA DE MEIO AMBIENTE DO ESTADO DE SÃO PAULO - SMA. Lei $\mathbf{n}$. 997, de 31 de maio de 1976. Disponível em: <http://www.ambiente.sp.gov.br/uploads/arquivos/legislacoesambientais/1976_Lei_E st_997.pdf>. Acessos em: 20 mai. 2007.

SHEN, Y.; HUTCHINS, S. R.; WEST, C. In vitro cytotoxicity of aromatic aerobic biotransformation products in bluegill sunfish BF-2 cells. Ecotoxicology and Environmental Safety, v. 45, n. 1, p. 27-32, 2000.

SHOKOOHI, R.; HAJIA, M.; JAFARI, A. J.; MOVAHEDIAN, H.; PARVARESH, A. Identification of phenol degrader microorganisms in the integrated BF/AS combined system. Pakistan Journal of Biological Sciences, vol. 9, n. 2, p. 223-226, 2006.

SPOSITO, R. D. Definição de alternativas de pré-tratamento de efluentes nãodomésticos em sistemas públicos de esgotos, utilizando o teste de avaliação da toxicidade refratária. $221 \mathrm{f}$. Dissertação (Mestrado em Engenharia) - Escola Politécnica, Universidade de São Paulo, São Paulo, 2006.

SUOMINEN, K. P.; WITTMANN, C.; LIUKKONEN, M.; KÄHKÖNEN, M. A.; SALKINOJA-SALONEN, M. S. Ecotoxicological assessment of a recipient lake sediment of bleached-kraft pulping discharges. Environmental Toxicology and Chemistry, v. 18, n. 10, p. 2262-2267, 1999.

TRIGUEROS, D. E. G. Avaliação da cinética de biodegradação dos compostos tóxicos: benzeno, tolueno, etilbenzeno, xileno (BTEX) e fenol. 157 f. Dissertação (Mestrado em Engenharia Química) - Centro de Ciências Exatas, Universidade Estadual do Oeste do Paraná, Toledo, 2008.

UNIVERSITY OF MINNESOTA. Biocatalysis / Biodegradation Database. Disponível em: <http://umbbd.msi.umn.edu> Acesso em: 5 abr. 2008. 
VAN ELSAS, J. D.; VAN OVERBEEK, L. S.; VAN VEEN, J. A. Fate and activity of microrganisms introduced into soil. Microbiologya and Molecular Biology Reviews, v. 61, p. 121, 1997.

VANROLLEGHEM, P.; COEN, F.; KONG, Z. Full-scale on-line assessment of toxic wastewaters causing change in biodegradation model structure and parameters. Water Science and Technology, v. 33, n. 3, p. 163-175, 1996.

WILSON, J.T.; ENFIELD, C. G.; DUNLAP, W. J.; COSBY, R. L.; FOSTER, D. A.; BASKIN, L. B. Transport and fate of selected organic pollutants in a sandy soil. Journal of Environmental Quality, v. 10, n. 4, p. 501-507, 1981.

WILSON, J.T.; MCNABB, J. F.; WILSON, B. H.; NOONAN, M. J. Biotransformation of selected organic pollutants in ground water. In: GENERAL MEETING OF THE SOCIETY OF INDUSTRIAL MICROBIOLOGY, 39., 1983, Saint Paul. Proceedings... St. Paul: Society of Industrial Microbiology, 1983, p. 225-233.

WITTHAUER, D. P. Biocoenosis and degradation in model wastewater treatment plants. European Journal of Applied Microbiology and Biotechnology, v. 9, p. 151-163, 1980.

WOLSKI, E. A.; GONZALES, J. F.; MURIALDO, S. E. Effect of pH and inoculum size on pentachlorophenol degradation by Pseudomonas sp. Water S. A., v. 32, n. 1, 2006.

XUN, L.; BOHUSLAVEK, J.; MIAN, C. Characterization of 2,6-dichloro- $p$ hydroquinone 1,2-dioxygenase (PcpA) of Sphingomonas chlorophenolica ATCC 39723. Biochemical and Biophysical Research Communications, v. 266, n. 2, p. 322-325, 1999.

YOUNG, J. C. Cleaners and disinfectants agents can inhibit reactions in treatment processes. Industrial Wastewater, v. 1, p. 7-11, 2008. 